\title{
Emberi ábrázolás a Változások korában, 4000 és 2000 BC között
}

\author{
HORVÁTH TÜNDE \\ MTA BTK Régészeti Intézete \\ H-108 Budapest, Korányi Sándor út 10., e-mail: tundehorvath4@gmail.com
}

\author{
„Ultima ratio regum" \\ (vésés XIV. Lajos ágyúin)
}

HoRVÁtH, T.: Human depictions in the Age of Transformation, between 4000 and 2000 BC.

Abstract: Our survey should by necessity begin earlier, from the close of the Middle Age Copper Age, and should extend to much later, at least until the onset of the Middle Bronze Age, in order to identify and analyse the appearance and spread of the cultural impacts affecting the Baden complex, their interaction with neighbouring cultures and, finally, their decline or transformation. Discussed here will be the archaeological cultures flourishing between 4200/4000 and 2200/2000 BC, from the late phase of the Middle Copper Age to its end (3600 $\mathrm{BC}$ ), the Late Copper Age (ending in $2800 \mathrm{BC}$ ), the transition between the Copper Age and the Bronze Age (ending in $2600 \mathrm{BC}$ ), and the Early Bronze Age 1-3 (ending in 2000 $\mathrm{BC})$, which I have termed the Age of Transformation.

Keywords: Human depiction, end of the Middle Copper Age, Late Copper Age, Early Bronze Age, spiritualism, cultural antropology

\section{Bevezetés}

A tanulmány eredeti témája az emberi ábrázolás a késő rézkori Baden-komplexumban. Az egyszerűnek és világosnak tünő mondat azonban több tekintetben félrevezető lehet, és ebben az esetben újszerü, a szakirodalomban eddig nem szereplő jelentéssel telik meg.

Egyrészt kulturális tekintetben. Az alábbiak során a Baden-komplexumon a Boleráz és a Baden kultúrákat értem, de a Bolerázt a komplexum részeként, és a Badennel többféle módon interakcióban, vele elválaszthatatlanul, de mégis bizonyítottan önálló régészeti kultúraként is tárgyalom (HORVÁTH 2009, 2012, 2014).

Másrészt kronológiai tekintetben. Az eddigi szakirodalomban post-badeninek nevezett önálló Jevišovice/ Bošáca, Řivnác, Kostolác, Vučedol kultúrákat kronológiailag a Badennel részben, és talán még a Bolerázzal is érintkező, velük egykorú kultúráknak látom, a postbadeni elnevezés tehát nem indokolt. Mivel Magyarország területén az itt előforduló Kostolác és Vučedol minden esetben Badennel együtt jelentkezik a lelőhelyeken, én ezeket külön kultúrákként, de a Badennel részben egy időben, és vele közösen élő kultúrákként a Baden-komplexum részeként kezelem, hasonlóan a Bolerázhoz. Más országokban az említett kultúrák önálló lelőhelyekkel is jelentkeznek, így ott ez a helyzet nem tartható fenn.

Továbbá, a Baden kultúra továbbélése 2800 BC után 2600 BC-ig az átmeneti periódusban, majd a kora bronzkor 1, és lehetséges továbbélése a kora bronzkor 2 és 3. fázisokban tovább tágítja a Baden életét a kora bronzkor időszakában is. A Baden kultúra esetében tehát már nem csak késő rézkori ábrázolásokról beszélünk. Ahhoz, hogy a munkában helytálló következtetésekre jussunk, szükségünk van a Baden-komplexummal szomszédos és egyidős kultúrák, elsősorban a Gödörsíros kurgánok emlékanyagának vizsgálatára is.

Természetesen, a vizsgálatot korábban, a középső rézkor vége időszaknál kell kezdenünk, és legalább a középső bronzkor kezdetéig folytatnunk, hogy a Baden-komplexumra jellemző hatások felbukkanását, terjedését, szomszédos kultúrákkal való kapcsolatait és eltűnését, vagy változásait láthassuk és vizsgálhassuk. Az itt vizsgált időszak különböző régészeti kultúrákkal 4200/4000-2200/2000 BC között a középső rézkor vége (3600 $\mathrm{BC}$-ig), a késő rézkor (2800 BC-ig), a rézkor és bronzkor közti átmeneti időszak (2600 BCig), és a kora bronzkor 1-3 időszakokat fedi le (2000 BC-ig), amelyet úgy nevezek: a Változások kora.

A Baden-komplexumban jellemző emberi ábrázolások eddig ismert előforduló típusai az alábbiak:

1. agyagmüvesség: antropomorf szobrocskák (idolok);

2. agyagművesség: maszk;

3. agyagművesség: antropomorf vonásokkal felruházott edények;

4. kőmegmunkálás: sztélék/menhírek.

A munkát ebben a lelettípusokra bontott sorrendben tárgyalom, elsősorban a Kárpát-medence, mint törzsterület leletanyagára koncentrálva, ám indokolt esetekben kitérve további, akár távoli példákra Badenkomplexumon belül vagy kívül.

\section{Módszertani szempontok}

Nagyon fontosnak tartom a lényegi rész tárgyalása előtt néhány fontos szempontra felhívni a figyelmet. Ha valóban előrelépést szeretnénk tenni ezen a területen (vagy bármilyen ősrégészeti kérdésben, és feltételezem, hogy a válasz a kérdésre alapvetően: igen), akkor szakítanunk kell az eddigi közlési és megközelítési gyakorlattal, és radikálisan meg kell változtatni a témához való hozzáállásunkat. Általánosságban elmondható, hogy az eddigi publikációk tárgyleíró és ábrázoló részei változatos terjedelműek és részlet-igényesek, de egy sem közelíti meg a kellő színvonalat ahhoz, hogy a tárgy eredeti ásatóján/közlőjén kívül további kutatók is ugyanannyi információhoz jussanak későbbi munkájuk során, mint az eredeti publikáló/feltáró. 
Az első közlésnek mindig nagyon részletesnek kell lennie, minden, a lelettel kapcsolatban jellemző adat közlésével, jó minőségű, több nézetű rajzokkal és fotókkal kiegészítve, legyen az bármilyen hétköznapi, vagy épp semmitmondónak tűnő. Az utólagos gyüjtések és későbbi értékelések során újabb vizsgálati szempontok merülhetnek fel, de ebben a stádiumban még nem lehet tudni, mely azonosítók/jellemzők fognak fontos szerephez jutni. Mindezeken felül tartalmaznia kell a jelenség leírását, amelyben a lelet előkerült, további erre vonatkozó részletes ábraanyaggal, és a jelenségben található valamennyi előkerült lelet bemutatását, mivel ezeknek a felbukkanása kapcsolatba hozható a vizsgált lelet felbukkanásával. Ezzel azonban még mindig nem fejeztük be! Egyetlen antropomorf figurát például talán többféle rítuson, vagy talán több rítusból álló ceremónia-sorozaton is használtak, ezért a jelenség környezetének leírását is be kell vonnunk az értékelésbe. Az minden lelőhelyen változó, hogy mekkora területet érinthetnek az egymással összekapcsolható objektumok: érdemes a restaurálás során az összetartozó leletek legnagyobb távolságát venni példának, amely tafonómiai mértékegységként is szolgálhat egyúttal lelőhelyünkön. Ugyanakkor a környező objektumok értékelésbe vonása azon okból is szükségszerü, mivel a legtöbb őskori rituális tárgy szándékosan eltörve, manájától megfosztva, másodlagos funkcióban és másodlagos helyen található. Igényes nyomozással és a másodlagos környezet aprólékos megfigyelésével azonban következtetni lehet az eredeti, primer használatra.

A Baden szakrális leletek, főleg az idolok többsége szórványként került elö, ezért mindenfajta, a szentet és a rítusokat feszegető elvont témákhoz, de még a tárgy egykori, talán akár teljesen hétköznapi vagy másodlagos funkciójához (pl. gyerekjáték, azonosító token, stb.) szükséges azonosító/bizonyító háttér-adatokat is nélkülözik. Semmire nem jók egy igényes vallástörténeti-régészeti értékelésben, mint a térképen és a katalógusban a lelőhelyek számának növeléséhez. Többségüket még mint tárgyat is hiányosan írták le és ábrázolták, ezért egy alapvető tipológiai meghatározáshoz, formai osztályozáshoz sem rendelkeznek elegendő információval a későbbi kutató számára (pl. hány lyuk van a törzsben a fej(ek) számára, mekkora rész került elő és mekkora a kiegészítés, stb.). Ezt a hiányt csak a lelet személyes megkeresésével és újbóli bemutatásával lehetne elkerülni, ha ez nem lenne szinte a lehetetlennel határos amiatt, hogy nem kapunk rá engedélyt kutatótársainktól. A lelet és a lelőhely viszonyáról már szinte egyetlen publikációban sem esik említés, márpedig az új kronológiai és kulturális változások miatt ma már egyáltalán nem mindegy, hogy egy bolerázi, egy badeni, egy bolerázi-badeni, badeni-kostoláci, badeni-gödörsíros kurgán, vagy egy kora bronzkorban továbbélő badeni településen, sírban, temetőben került-e elő. Ugyancsak nincs információ a tárgyat őrző objektum jellegéről (gödör, ház, kemence, kultúrréteg, temetkezés temetőben vagy településen?). Sajnálatos módon a nem szórványként előkerült leletek többségé- re is ez a szomorú és siralmas közlési állapot jellemző (Id. Tököl, egyedi tárgyleírások nélkül: KALıCz 2002). Emiatt nem tudtunk elörelépni sok kérdésben évtizedekig. Az egyre finomabb osztályozási szempontok felállításához és érvényesítéséhez egyre finomabb feltárási és dokumentálási/közlési módszerek szükségesek, különösen olyan régészeti kultúra-komplexumok esetében, amelyek egy látszólagos szinten tipológiai azonosságot mutatnak, és nagy területen terjedtek el. Látható és eredménnyel járó folyamatok zajlottak le az elmúlt évtizedekben ilyen területen pl. a hasonló adottságú Harangedényes, Zsinegdíszes, Gömbamfórás kultúrák esetében, vagy az őskori és későbbi, népvándorláskori ún. steppei népek esetében. Ez a folyamat vette kezdetét a Baden-komplexum Balatonőszödön feltárt, eddig legnagyobb lelöhelyével (a szent manifesztálódásának három különböző, de egymással összekapcsolt cikk-sorozatot szenteltem a szakrális jelenségek, edények és tárgyak témájában, Id. HoRvÁTH 2010, 2010b, 2010c), és vezetett számos esetben radikális, bizonyított változásokhoz, amelyet a témákat tárgyaló különböző publikációk mellett más kutatók is személyesen ellenőrizni tudnak a saját leírásuk és megközelítésük megteremtésével a teljes dokumentáció közrebocsátása után (HONTI-HORVÁTH 2013). Egyetlen lelőhely azonban semmit nem jelent, amíg nem követik továbbiak, amelyek vagy alátámasztják, vagy módosítják, vagy megcáfolják a véleményemet, és ezzel magasabb és általánosabb értékelési szintre emelik azt.

\section{Agyagművesség: antropomorf szobrocskák (idolok)}

\subsection{Középső rézkor vége}

A klasszikus középső rézkortól világosan elválasztva 4000 BC-től Magyarország területén az ún. középső rézkor vége időszakban (4000-3600 BC közt) a középső rézkorban már meglevő (Ludanice/Epi-Lengyel/Lengyel V és/vagy Balaton-Lasinja; Bodrogkeresztúr); és néhány új kultúrát találunk (Hunyadi-halom/Lažňany), esetenként egymással is erősen keveredett (pl. ÉNyMagyarországon, Győr-Szabadrét-domb: VIRÁG 2004; vagy Abony-49. lelőhely: RAJNA 2011), minden esetben Furchenstich-díszítésű leletanyaggal kiegészülve. A klasszikus középső rézkorra jellemző világos kultúrahatárok és status quo nyilván emiatt is lazábban körvonalazódik, és nem segíti a korszak kutatását a kevés, jellegtelen, sokszor publikálatlan lelöhely sem, amelyek között feltűnően kevés a temetkezés.

A bizonytalanságoktól függetlenül két fontos tényezőt hangsúlyoznék. Az egyik az, hogy ezt a 4000 BCtől kb. 3600 BC-ig, a Boleráz megjelenéséig (amely egyúttal a késő rézkor kezdete) tartó időszakot világosan és határozottan válasszuk le a klasszikus középső rézkorról. A keveredés miatt ne beszéljünk kultúrákról (pl. Furchenstich kultúráról, vagy proto-Bolerázról). Ruttkay Erzsébet után (RUTTKAY 1999: 138-145) én magam is úgy vélem, hogy ez a horizont leginkább a Furchenstichhel kiegészült keveredéssel írható 


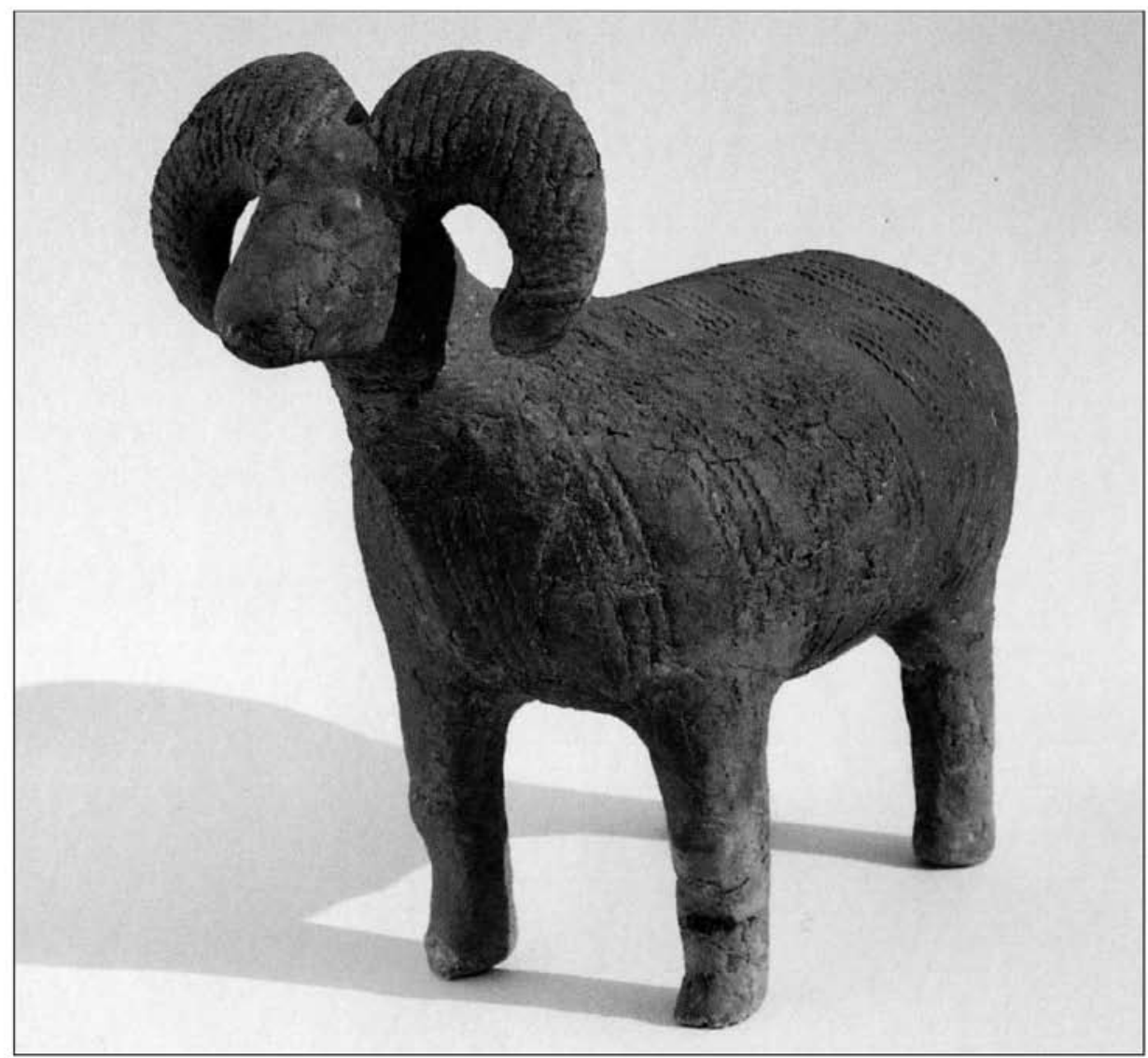

1.

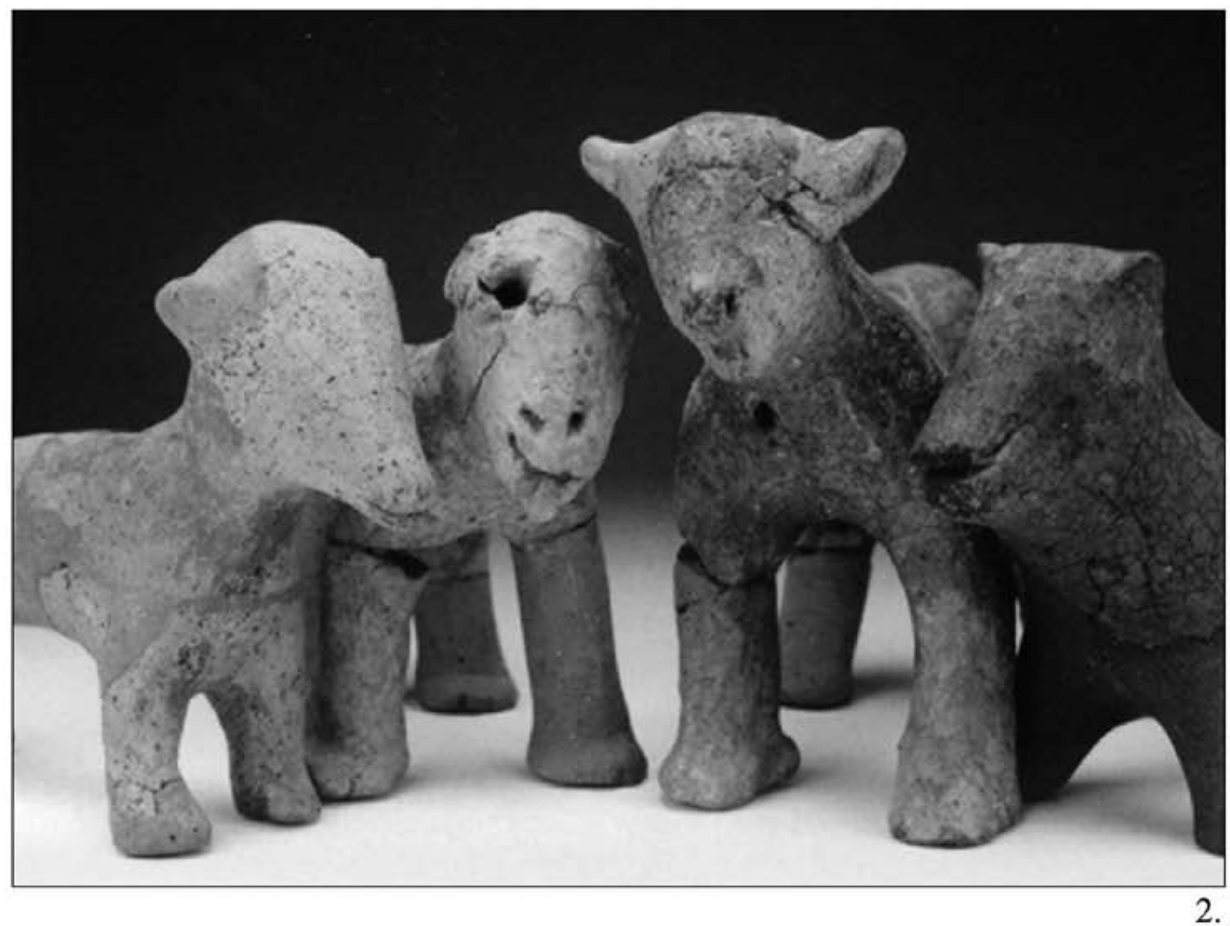

1. Tábla: 1. Zsirfarú vagy zsirfarkú juh-szobor a Jordanów kultúrából, feltehetően már szövés-fonásra alkalmas gyapjútakaróval, Jordanów-Śląski, középső rézkor vége, Wohin die Toten gehen 2000: Abb. 69 után.

2. Pilismarót-Basaharc. A Boleráz temetöben sírok közt talált állatszobrocskák a MNM képeslapja után. 

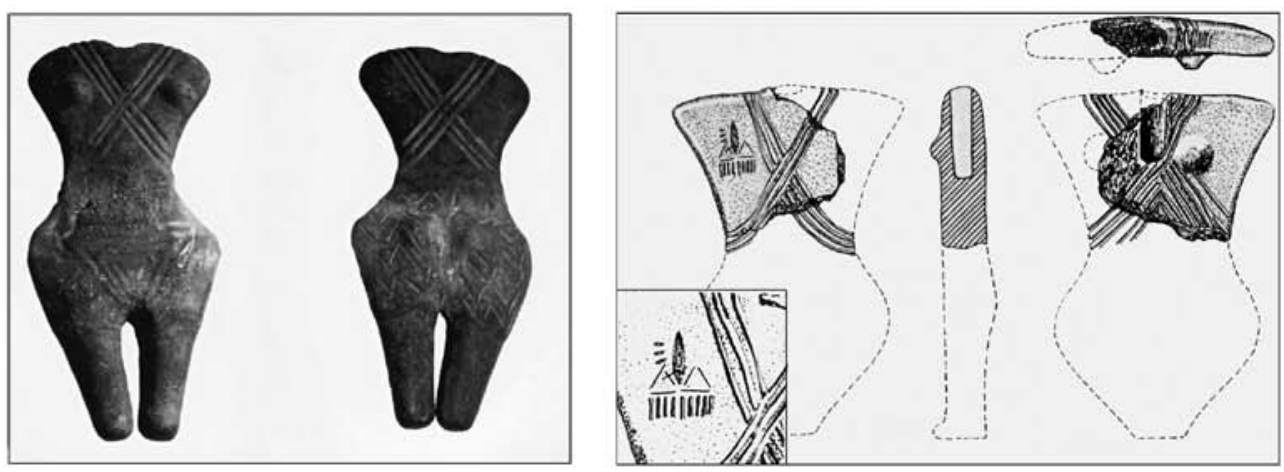

1.
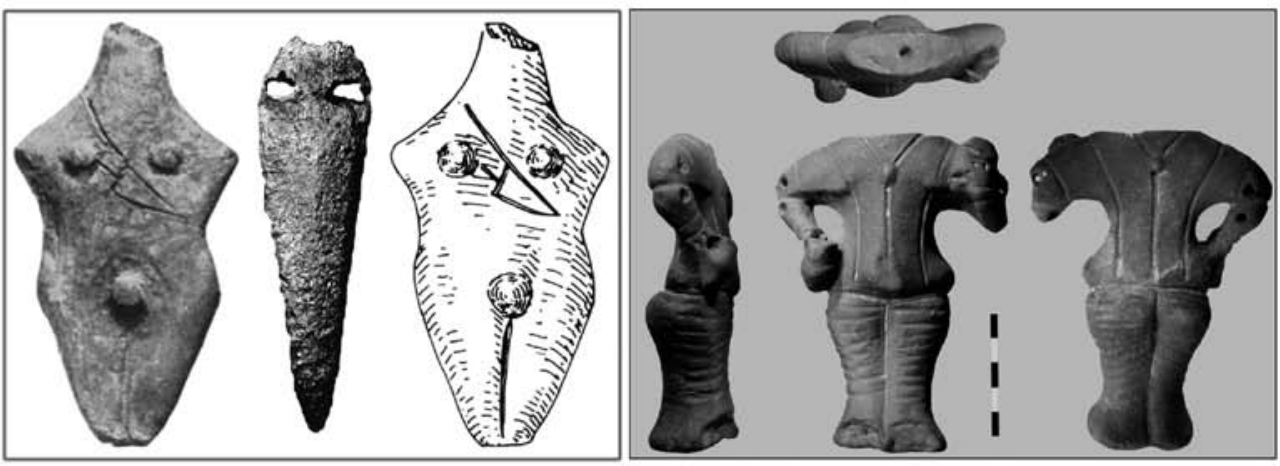

3.

4.

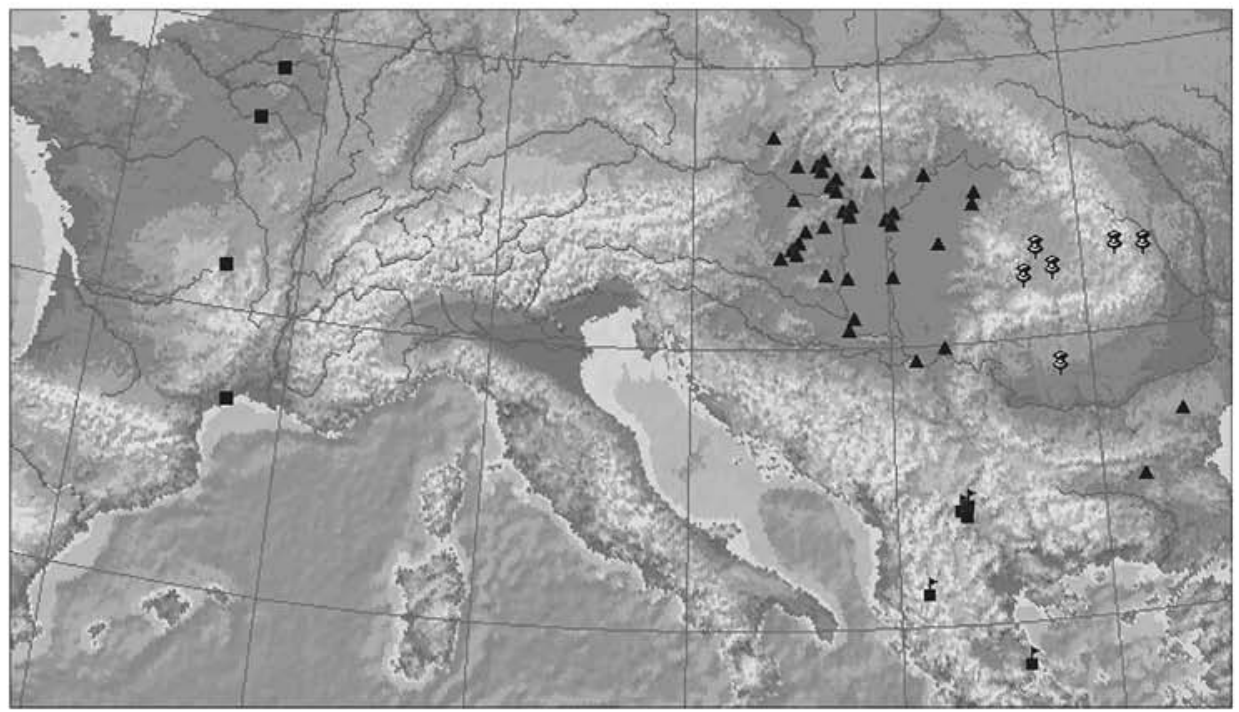

5.

2. Tábla: 1. A Baden kultúra tipikus idolja Budapest-Káposztásmegyerröl, zsírfarú típus, Endrődi 2004: $28,40$. kép, Cat. 106. után. 2. A Baden kultúra tipikus idolja vállán „mezopotámiai piktogrammal” Tökölröl Kalicz 2002: Abb 11: 2. után. 3. A Baden kultúra atipikus, lapos férfi idolja törrel és egyes mellszalaggal Cernavodă-Dealul

Sofia lelőhelyről Dumitrescu 1974: Fig. 289: 3. után, és az idolon ábrázolt réztőr formai mása Sármellék-

Égen-föld lelöhelyröl, Visy 2003: 132, Abb. 18. után. 4. Liubcova/Alsólupkó, az első cserélhető fejü idol kezében maszkkal az őskorban a Vinča kultúrából, Schier 2005. Abb. 61. után. 5. A thesszáliai típusú lapos, női, fej nélküli idolok elterjedése a középső rézkor vége-késő rézkor időszakokban Horváth 2007 után. Jelkulcs: Négyzet: Ny-Franciaország, háromszög: Baden, rajzszög: Coţofeni, zászlós négyzet: Dimini-Rachmani kultúrák. 
le, minden szituációban a maga saját modelljével és arányaival. Beszélhetünk nálunk pl. Furchenstichhel kevert Balaton-Lasinja vagy Furchenstichhel kevert Bodrogkeresztúr középső rézkor végi lelőhelyekről, de nincs bizonyítékunk arra, hogy önálló Furchenstich kultúráról beszéljünk Magyarország területén.

Ugyanez a helyzet a proto-Bolerázzal, és ez lenne a második hangsúlyos pont. A középső rézkor vége időszakot Kalicz Nándor klasszikus középső rézkori dunántúli hármas felosztása után (Balaton-Lasinja: I/Furchenstich: II/Proto-Boleráz: III: pl. KaLICZ 1973) sokan azonosították hol Furchenstich II hol protobolerázi III időszakként. Ez az elnevezés helytelen abból a szempontból, hogy Magyarországon ebben a korszakban nincsenek a Bolerázt bevezető „proto” vagy átmeneti formák, ezért tipológiailag nem indokolt és rendkívül félrevezető a proto-bolerázi időszak elnevezés, még ha kronológiailag valóban nem is helytelen, mivel időben tényleg a Boleráz előtt található. Magyarország területére a Boleráz kultúra teljesen kifejlett formában, észak felől, a Duna vonalát követve érkezik, és nem helyben alakul ki. Ezért a protobolerázi kifejezés használata mind kronológiai és mind tipológiai értelemben helyesen csak a morvaországi kialakulási területet illeti meg.

A középső rézkor végi időszakot a temetkezési szokások terén (amely kiinduló- vagy végpontja lehet mindenfajta emberi ábrázolásnak is, mivel ők reprezentálják az egykori eredeti populációt, életükben pedig a sprituális képzeteket alakították) föleg hamvasztásos, urnás temetkezések jelzik, amelyek településeken belül kerülnek elő. Nem ritkák azonban a különböző körülmények közt napvilágra került csontvázas temetkezések vagy izolált csontok sem, amelyek a szakirodalomban „áldozatok”-ként kerültek leírásra (konkrét bizonyítékok ellenére, pusztán a lelőhely-körülményekböl kifolyóan, pl. Ludanice települési és barlangi lelöhelyekről, összefoglalóan: BISTÁKOVÁ-PAžINOVÁ 2010: 154-156; továbbá Balaton-Lasinja temetkezések és kultikus középső rézkori kút-leletek: HoRvÁtH et al. 2003: 271-272, 284).

Általánosságban megfogalmazható, hogy az idolplasztika a kora rézkortól hanyatlást mutat a korábbi korszakokkal összevetve, még a kontinuus Lengyel örökösének tartott Ludanice és talán Balaton-Lasinja kultúrákat tekintve is (a Balaton-Lasinja Magyarországon egyes kutatók szerint epi-Lengyel, mások szerint déli hatások alakítják ez mellett vagy enélkül, a probléma összefoglalásaként: VIRÁG 2005). Ennek oka több tényezőt is magába foglalhat: csökkenhet a közel-keleti-balkáni kultúr-hatás; magától vagy az előbbivel öszszefüggésben kialakulhatnak és erősödhetnek a helyi tradíciók (vö. körárkok kialakulása Közép-Európában); a késő neolitikus tellek megszűnésével és az éghajlat fluktuálása miatt hanyatlik a földművelés, amelynek termékenységkultuszai közé sorolják az idol-plasztikát, és végül kevésbé érvényesül az egy helyben való tartós letelepedés is, amely a kultuszok bemutatását települési szinten segíti.
Sem a kora rézkori Tiszapolgár (KaLICz 1979-1980: 55), sem a Bodrogkeresztúr kultúrából, amennyiben utóbbinak létezik középső rézkor végi kevert lelőhelye, nem ismerünk emberi ábrázolást (vö. RAJNA 2011; PATAY 1989: 34). A középső rézkor vége időszak keveredéséhez, és a Baden déli kialakulási központjához azonban talán fontos szálat jelentenek az ún. Jakšič típusú leletek. Szentes-Kistőkén pl. tipikus bodrogkeresztúri sírban tipikus bodrogkeresztúri edények közt találták azt az egyfülü korsót, amelynek díszítése Balaton-Lasinja, de már akár Baden jelleget is mutathat (HoRVÁTH 2012: 18, PI. 103: 6).

A Hunyadi-halom/Lažňany kultúrát, amely részben a klasszikus középső rézkori Bodrogkeresztúr utáni, részben annak középső rézkor végi időszakával egyidős kultúra, a Bodrogkeresztúrnál fejlettebb és gyakoribb emberábrázolás jellemzi. Hiteles körülmények közt előkerült egyszerű idolját, amely kiemelkedő fejvagy nyakrésszel, felemelt tartású karokkal rendelkezik, Tiszaluc-Sarkadon tárták fel (PATAY 2005: Taf. 54: 3). Érdekessége, hogy középen, melltájékon van átfúrva, hasonlóan, mint néhány, a korszakból ismert arany korong- és rája alakú függő, amelyet néhányan szintén nagyon sematikus emberábrázolásnak tartanak. A nem hiteles körülmények között, bár feltáráson előkerült Tiszafüred-majorosi lelet ettől teljesen eltérő (KALICZ 1979-1980: 52). Arca maszkszerű, felfelé fordított, ép füle átfúrt, karjaival a mellkas és a has előtt. Alsó törése alapján úgy vélik, nem is idol, hanem fedő fogantyúja volt. Nem biztos, hogy valóban a kultúra hagyatékába tartozik, bár a lelőhelyen feltártak öt Hunyadi-halmi gödröt, a három idol-töredék - köztük ez a lelet - szórványként, kutatószelvényböl került elő. Azonosításuk formai alapon a szegényes hiteles leletanyag mellett, amivel a korszak és a kultúra rendelkezik, nem meggyőző (egyáltalán nem hasonlít pl. a tiszaluci leletre, bár lehet azért, mert nem idol, hanem edény darabja). A kérdés azonban jogos, mivel a korábban hunyadi-halminak tartott szelevényi négyszögletes edényen látható emberi ábrázolás esetében is egyértelműen kiderült (4. Tábla: 1), hogy nem a kultúra, és nem is a korszak lelete (vö. HORVÁtH-BALEN 2012).

A Balaton-Lasinja kultúrából Magyarországról nem ismerünk emberi ábrázolást, bár Szombathelyen, a Plachner-féle kavicsbányában 3 méter mélyen előkerült egy enyhén hátrahajtott fejü, igen hosszú nyakú, bal fülén átfúrt idol töredéke, amelyből egy $50 \mathrm{~cm}$-nél magasabb, a tiszai kultúra leleteihez hasonló nagy szobrot rekonstruáltak. Fülében feltehetően igazi réz vagy arany fülbevaló lehetett (KALICZ 2007: 17, 29, 250-253; Kat. 170). Ez a szobor azonban, ha valóban a kultúra hagyatékát képezi, annak klasszikus középső rézkori időszakából való, déli párhuzamai alapján. Kögelbergen, magaslati településen tárták fel a Kanzianiberg-Lasinja körből azt a fejet, amely sematikusságában és dőlésében a szombathelyi töredékhez hasonlít (RUTTKAY 1997). Magyarország területén kívül, a Lasinja kultúrából néhány idol ismert. Jellegzetességük, hogy nem tipizálhatók: szinte mind más formát 
jelenít meg (DIMıTRIJEVIĆ 1976). A kultúrához való tartozásuk is bizonytalan, mivel maga az időszak, benne a Balaton-Lasinja kultúrával is számos változáson ment keresztül.

Magyarország területén a Furchenstich-díszítésű idol-töredékeket soroljuk biztonságosan ebbe a középső rézkor végi „kevert” időszakba (pl. Becsvölgye, Nagytarcsa, Bagod: HAvası 2006; Kalıcz 2007). Közös jellemzőjük az, hogy nőket ábrázolnak. A leleteket általában derék-csípő-lábrészükön törött darabokként azonosítják (ebben a régióban törnek, és ezek maradnak meg a települési objektumokban). Teljes testfelületükön dúsan bekarcolt, fehér meszes berakással díszített vonalak láthatók, amelyek talán ruhát, talán testfestést/tetoválást jelenítenek meg. A Graz-iellá-nak nevezett ausztriai leletből feltételezhető, hogy nyúlványszerűen, talán a nyakat, talán a sematikus fejet ábrázolva végződtek (RUTTKAY-KRAMER 2004). További érdekességük a paleolitikum/korai neolitikum-törés (összefoglalóan Id. pl. FEKETE 2004) után visszatérő fizikai/anatómiai jellegzetességük, több leleten a zsírfarúság (steatopygia) ábrázolásával (hasonlóan még a Tripolje-Cucuteni kultúrában vele egy időben is, annak Cucuteni B-Tripolje B2-C1 fázisaiban, vö. CucuTENI Culture Art and Religion 2009, Cat. 213-215, 217, 222-226, 238-239, 241, 249).

A középső rézkor vége időszak kezdete egyértelmüen azonosítható egy olyan éghajlati változás kezdetével, amikor a korábbi letelepedett, elsősorban földművelő kultúrák állattartásra és mobilisabb életmódra térnek, a keleti steppén megjelennek az első nomád kultúrák (HORVÁTH 2011: 95-96). A feltehetően kiszámíthatatlan, romló éghajlattal rendelkező hosszú periódusban, amely egészen a középső bronzkor kezdetéig tartott, kisebb-nagyobb javulások is voltak, ám a 4200/4000-2200/2000 BC közötti időszakot leginkább a földművelésre és a letelepedett életmódra kedvezőtlen éghajlat-ingadozás határozta meg. Talán nem véletlen, hogy a paleolitikum után ez a második olyan időszak az emberiség történetében (HORVÁTH 2014a), ahol az éghajlat hatása kimutatható és egyértelmü korrelációt mutat az ember anatómiai/fizikai felépítésével is. Bár a zsírfarúság feltehetően a korai neolitikum időszakában közel-keleti rítuselemként került a Kárpát-medencébe (nem biztos, hogy zsírfarú nők is eljutottak valójában a Kárpát-medencébe), attól eltérően ezek az idolok Északnyugat-Európára jellemzőek, és északnyugati irányú helyi (hegyi?) hatást jelentenek a Kárpát-medence területén, tényleges zsírfarú nők megjelenésével a saját populációjukban (ugyanezen a szálon a rézművesség és az alpi fém megjelenésével). Az éghajlati jelenség és az erre adott testi változás az ember anatómiai felépítésében, valamint ennek a mentális-esztétikai hasznossággal való összekötése „szépségeszményként” talán összekapcsolható az állattartás előretörésében az ugyancsak zsírfarú vagy zsírfarkú, feltehetően már szövés-fonásra is alkalmas gyapjat adó juhfajok megjelenésével is, amely szintén erre az időre tehető (vö. pl. Jordanów-Śląski, középső rézkor végi juhszobor ábrázolásával, WOHIN DIE TOTEN
GEHEN 2000: Abb. 69; HoRvÁTH 2006: 48. kép) (1. Tábla: 1). Ugyancsak érdekes klímatörténeti és anatómiai folytonosságra utal a zsírfarú női idolok megléte a Baden kultúrában (pl. Tököl: KALICZ 2002: Abb. 9:5, Abb. 11: 3; Vučedol: Kalıcz 2002: Abb. 20, Salačea: Kalicz 2002: Abb. 23: 3-4) (2. Tábla: 1).

Mindezektöl függetlenül, ahogy a településrégészeti kutatásokon nem sikerült ezzel az időszakkal és a késő rézkori Boleráz időszakkal folytonosságot kimutatni (HoRVÁTH 2014: 2. fejezet), úgy az idol-plasztikában sem találunk egyetlen olyan vonást sem a nő-ábrázoláson és a néha feltűnő zsírfarúságon kívül, amely a megelőző korszakból a késő rézkorba öröklődne a Kárpát-medencében.

\subsection{Késő rézkor}

A késő rézkor kezdetét a Kárpát-medencén belül a Boleráz kultúra felbukkanásától számítjuk, kb. 3600/3550 BC körültöl. A kultúra kifejlett formában, a Duna vonalát követve, észak-északnyugati irányból érkezik. Lelőhelyei nem fedik le az ország teljes területét, inkább bizonyos fajta folyók/vizek menti koncentrációt mutatnak (HORVÁTH 2009, HORVÁTH-SVINGOR 2014). A kialakulási (morva) területen feltűnő szórthamvas és urnás, ún. hosszú földhalmok alatti temetkezések szokása (BALDIA et al. 2008) a Kárpát-medencébe érve annyiban módosul, hogy az egyetlen önálló temetőben, Pilismarót-Basa-harcon már nem emelnek halmokat, pusztán kőpakolással jelzik a sírokat, és a temetkezések száma alapján ez egy sík, nagy sírszámú temető (ToRmA 1973), nem pedig megalitikus tradíciókat őrző, több személyt rejtő kollektív földhalmos temetkezés. Ezen kívül néhány, településeken előkerült csontvázas temetkezés (vagy áldozat?) tartozik a kultúrába (Balatonőszödön és Balatonlellén, Id. HORVÁTH-KÖHLER 2012), amelyek azonban már Baden-hatást mutatnak (a gödrök leletanyaga Boleráz IB-C-Baden IIA anyaggal kerültek elö).

M. Furholt volt az első, aki a Boleráz és Baden, azaz a korai és a késői emlékanyagot megpróbálta egymástól leválasztani, és az ebből adódó konzekvenciákat levonni. Arra jutott, hogy a tipikus badeni idolok nem fordulnak elő sem Ausztria, sem Morvaország területén: ez volt az első érvek egyike a Boleráz-Baden koherencia ellen (FURHOLT 2008: 618). Valójában van néhány atipikus (nem női, fej nélküli) idol az „északi” elterjedési területen is (a legészakibb előfordulásuk Brno-Lísen és Vel'ka Lomnicá/Kakaslomnic, egy szélességi fokon fekszenek: $49^{\circ} \mathrm{N}$, vö. HoRvátH 2010: Abb. 12) (2. Tábla: 5; 3. Tábla: 1).

Balatonőszödön 13 idol közül három olyan gödrökben került elö, amelyek Boleráz IB-C-Baden IIA átmeneti anyaggal voltak leírhatók. Elmondható tehát, hogy a Boleráz kultúra a Baden-komplexum részeként, de még önálló, Baden előtti időszakában (3600-3350 BC közt) nem készített emberi plasztikát, csak állati figurákat. Ezek a figurák feltűnően nagy méretüek, ahogyan az a középső rézkor végi időszakból, pl. a már említett Jordanów kultúrából származó zsírfarú juh-szobor esetében ismert számunkra (1. Tábla: 1). Itt tehát lehetett 

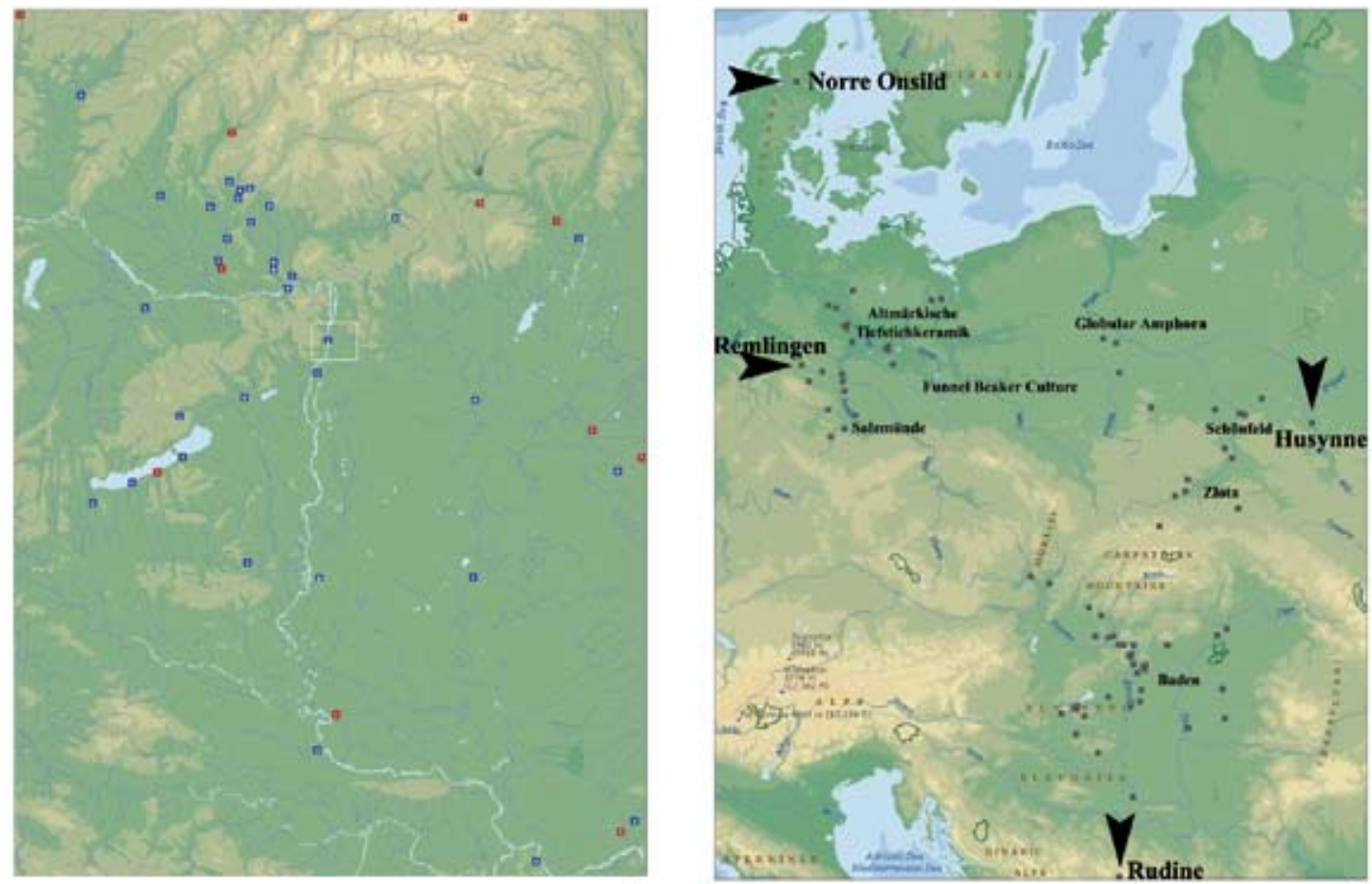

1.

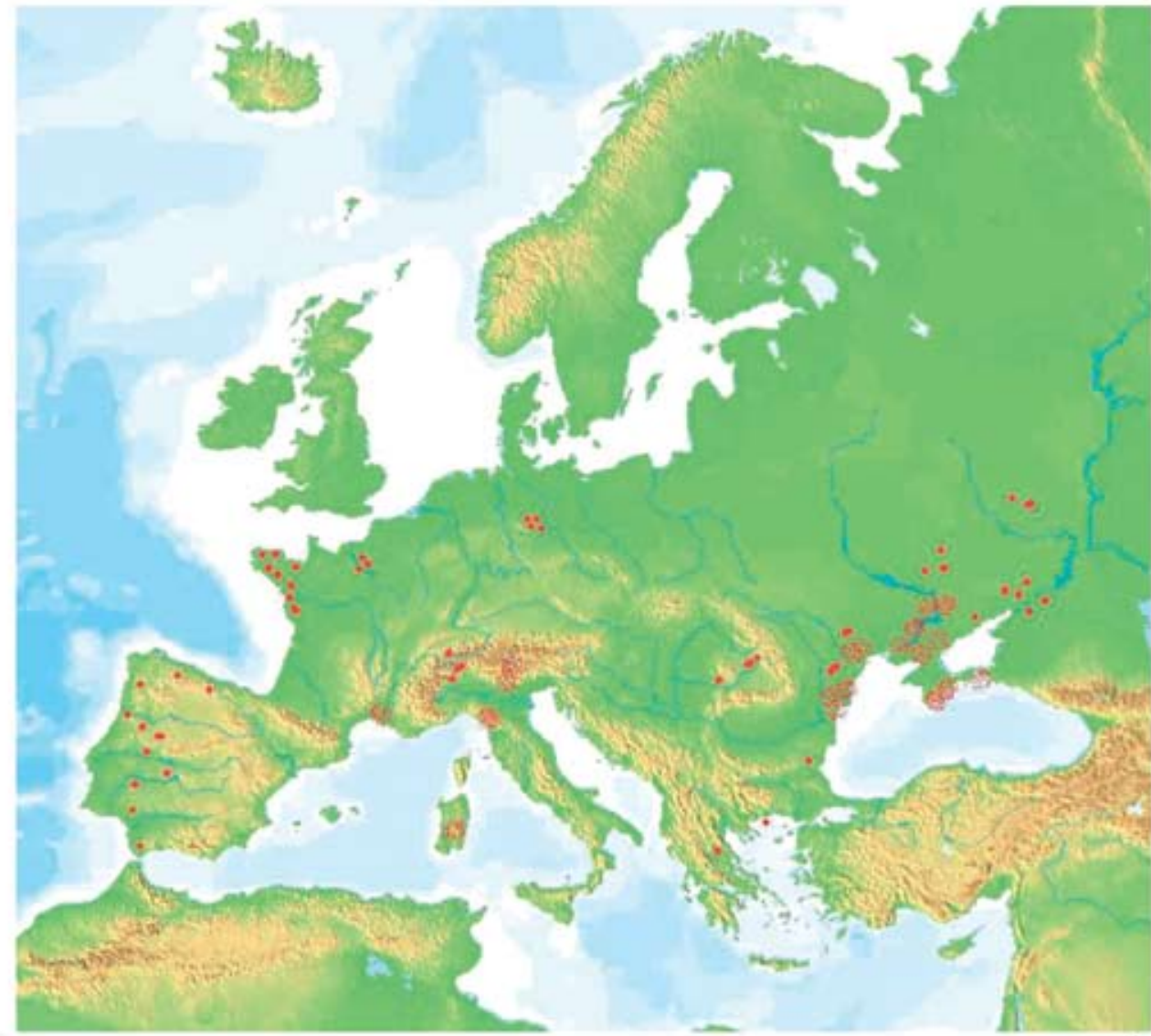

3.

3. Tábla: 1. Tipikus lapos, női, fej nélküli és atipikus Baden idolok elterjedése. 2. Szarvasmarha áldozatok 3500-2000 BC közt. 3. Sztélék és menhírek elterjedése 3500-2000 BC közt Dimitriadis 2008, Fig. 3. után. Foltok: több lelet koncentrációja, pontok: magányos sztélék 

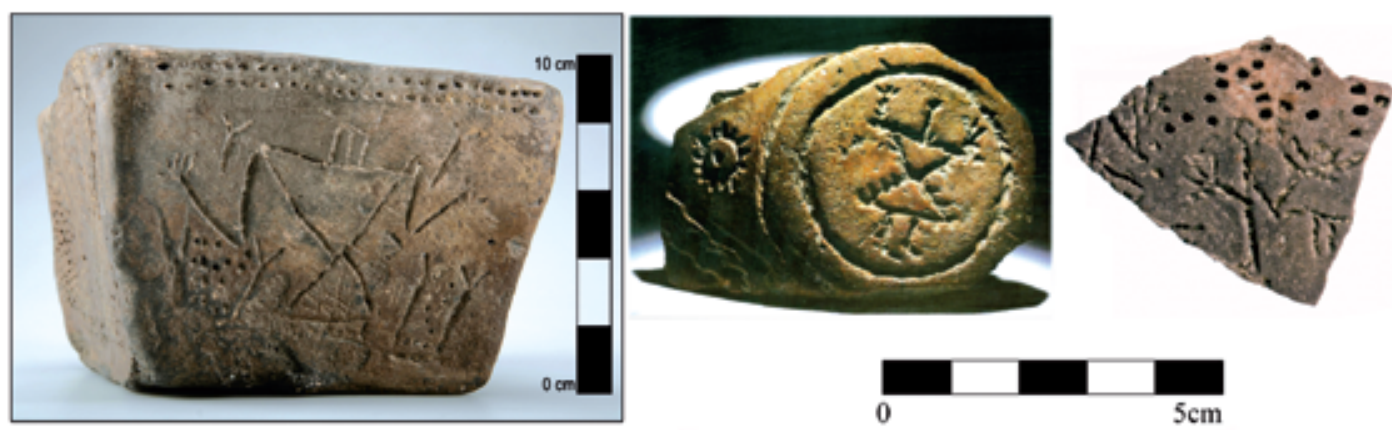

1.

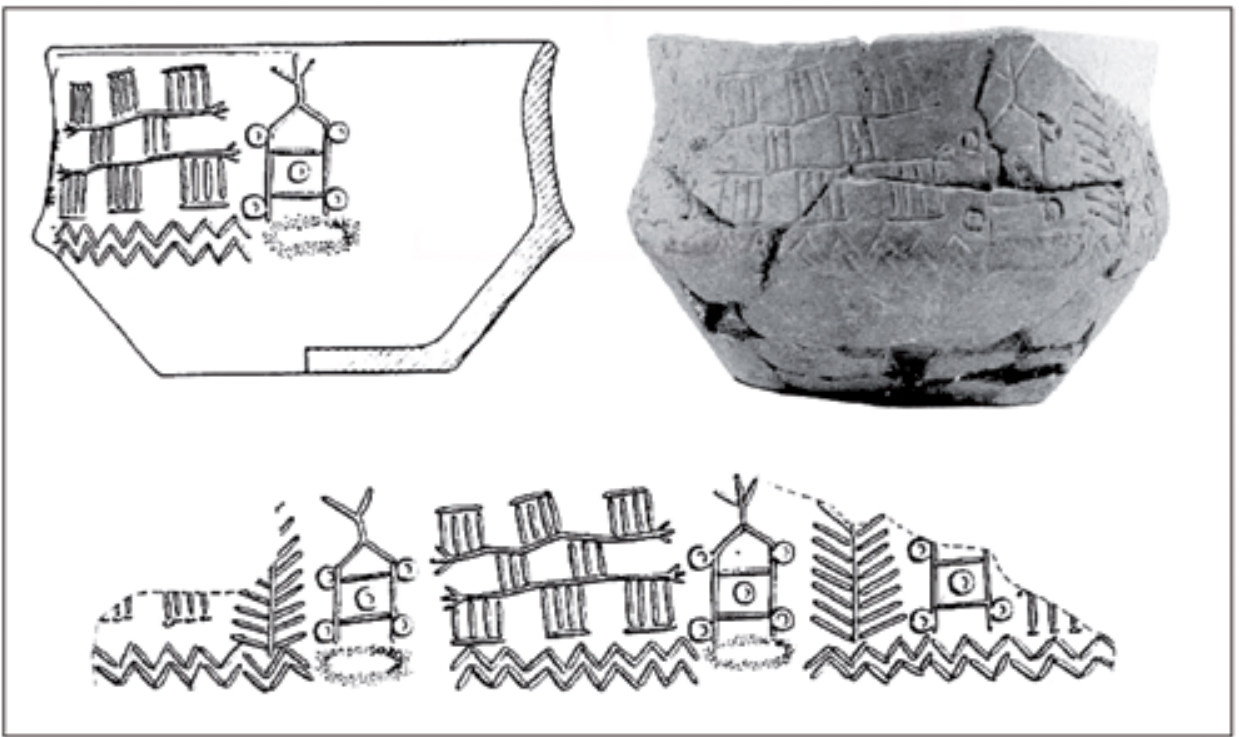

3.

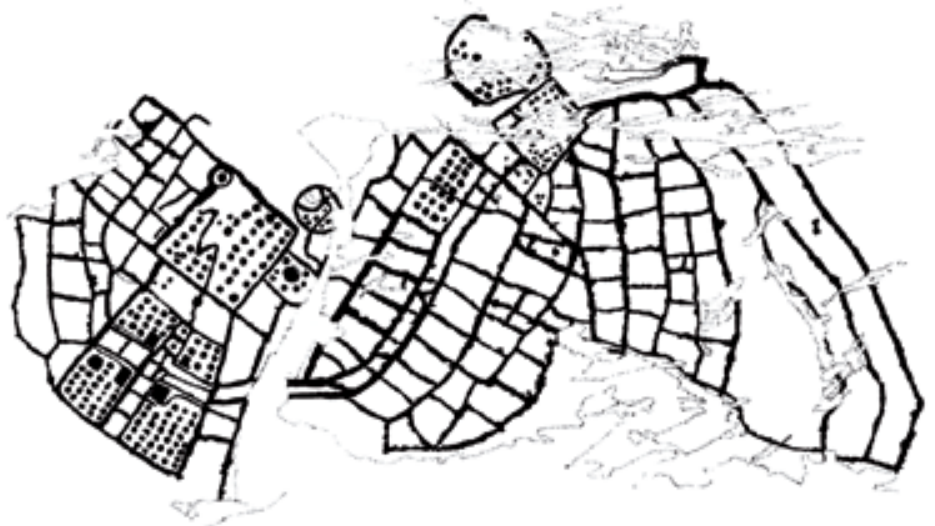

4.
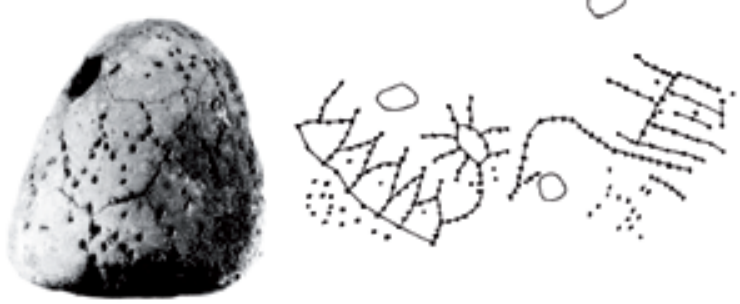

5.

4. Tábla. 1. Szelevény-Vadas, a négyszögletes edény oldalának fö kompozíciója ember-táj ábrázolással. 2. Vučedoli emberábrázolások edényekröl: a/Vučedol, Durman 2000: Fig. 45. után; b/Đakovo-Franjevac, Balen 2011: 96, Fig. 4: 8. után. 3. Bronocice, edény, Piggott 1983: Fig. 11. után. 4. Val Camonica, sziklavéset, Pétrequin et al. 2006: Fig. 27. után. 5. Feldmeielen-Vorderfeld, agyag nehezék, Leuzinger 2000: Abb. 260. után. 
egyfajta folytonosság, amely kulturálisan/genetikusan (?) is öröklődött Közép-Európa morva/lengyel területet érintő régiójában a kialakuló Boleráz és a megelőző Salzmünde/Baalberg Tölcséres szájú edényes csoportok között. Ilyen nagyméretű állatszobrok kerültek elő a pilismaróti temetőből (Torma 1972) (1. Tábla: 2). Mindezek után a Magyarországon szintén késő rézkorba sorolt, általában északkelet-magyarországi és szepességi szlovák hegyvidéki területről szórványként ismert kisméretű állatszobrokat nem tartom késő rézkorinak, mivel a magaslati lelőhelyeken (pl. Ózd, Vel'ka Lomnicá) nem fordult elő Boleráz, a Baden rétegeket pedig bronzkoriak (Makó, Hatvan, Piliny) követték. Sokkal valószínübb, hogy a kis állatfigurák a későbbi Hatvan vagy a Piliny kultúra hagyatékát képezik (vö. BANNER 1956: Taf. LXVIII: 4-6). A már Badennel érintkező időszakban 3350-3000/2800 BC közt a Boleráz ugyanazt az idol-típust készítette és használta, mint a Baden (nyilván Baden hatásra), és a településeken a Badenre jellemző csontvázas temetkezési rítust követte (amelyek azonban talán áldozatok, talán teleptemetkezések voltak, vö. HoRvÁTH 2014b).

A Baden jellegzetes idol-típusa lapos, kétdimenziós, nőt ábrázoló, fej helyével és legtöbbször hiányos vagy csonkolt végtagokkal megformált figura, amelyet két agyaglap-rétegböl hajtogattak össze, hasonlóan más badeni rituális tárgyakhoz (vö. épület-modellek) (2. Tábla: 1). Jellemzően a derék-csípő-részek kerülnek elö a települési gödrökböl, ritkábban a váll-mellkasi töredék. Kialakításukat tekintve a karcolt, ritkán vörösre festett, ruhát ábrázoló megjelenítés fordul elő a derékcsípő, esetleg háti részen, valamint a kannelúrával jelzett mellszalag a mellkason. A mellszalag (egyes vagy kettős) talán beavatási fokozatot árul el az indoeurópai tradíciók ismert beavatási rendszerében. Feltűnő azonban, hogy nőknek és férfiaknak is lehet, nemcsak férfiaknak. A mellszalagok ábrázolása feltünt az antropomorf jegyekkel ábrázolt edénytípusokon (kebles edények, de a kezes és lábas edényeken nem), és néhány korabeli sztélén, valamint épületeket díszítő plasztikán is (gynekomorf edények és sztélék, ld. később, ill. öszszefoglalóan: SchlichtHeRLE 2010) (5. Tábla: 5; 6. Tábla: 8). Anatómiai részeket a kezdetleges melldudorok és a nemi szervek jelenítenek meg: ez jelzi az idol nemét, bár a melldudorok alkalmazása nem következetes, mert férfiábrázolásokon is előfordulhat. Ahol tehát nem ábrázolják az elsődleges nemi jelleget, ott a melldudorok nem döntik el egyértelműen az idol nemét. $A$ fej helyére és egykori létezésére a nyaki részbe szúrt lyuk vagy lyukak árulkodnak (vannak idol-töredékek 2 és 3 lyukkal is: ez alapján feltételezik, hogy az idolnak egyszerre vagy egymás után több feje is lehetett). A feje(ke)t a feltételezések szerint pusztuló szerves anyagból készítették, ezért ezek nem maradtak fenn, de egykor hozzá tartoztak a teljes megjelenési képhez. Elképzelhető, hogy a fejek a beavatási rítusokon ugyannak a nőnek (vagy inkább korosztály-csoportjának, mivel az idolok sematikusak, nem portrészerüen kialakítottak, tehát nem individuumokat ábrázolnak, és a beavatási szertartások sem személyenként, hanem korcsoportonként zajlanak) a különböző életciklus-stádiumait jelenítették meg (serdülőből nővé, nőből anyává, anyából matrónává), és miniatürizálva, talán egy bábjáték-szerű életjelenet eljátszásával átsegítették őket a társadalmi és életkori küszöbhelyzeteken. Technológiai és jelentésbeli kialakításuknak semmi köze nincs a Bondár Mária által jordániai lelőhellyel kapcsolatba hozott leletnek, amely nem lapos-laphajtogatott, hanem tekercseléssel kialakított térplasztika, és ikervagy kettős-szobor; tehát két személyt ábrázol, ezért van két feje (BondÁr 2008: 173, Fig. 1)!

Ugyancsak túlzásnak tartom a bekarcolt finom jeleket közel-keleti piktogrammokkal kapcsolatba hozni (Kalicz 2002: 26, Abb. 11: 2a) (2. Tábla: 2). Sem időszakban, sem kialakításukban nem mutatnak párhuzamot az első mezopotámiai írásrendszerek és a badeni kultúra leletei. Esetleges hasonlóságot sokkal közelebb, a lelet saját idejében és térbeli környezetében jobbat találunk. A tököli idol vállának hátsó részén látható jel feloldása két egymás melletti, cölöplábakon álló ház oldalnézetben, és a kettő közt egy evezőkkel ellátott csónak felülnézetben. Ezeknek a terep- és tárgyszimbólumoknak a megjelenése Tökölön, a két ismert Baden temetőhöz, Alsónémedihez és Budakalászhoz közel (HoRvÁTH 2013), és a Baden magyarországi területén kimutatható cölöplábas épületek jelenléte mellett, közel az Esztergom-Szentkirályidűlőben feltárt épületekhez sokkal meggyőzőbb számomra (HoRVÁtH et al. 2007), mint egy mezopotámiai piktogramm-feloldás (5. Tábla).

Minden ilyen típusú idol, ha nem szórványként, akkor településeken kultúrrétegben, gödörben, és törötten került elö (kivétel az önálló, nem településen feltárt sírokban előkerülő egyetlen lelet: Méhi/Včelince, amely a legépebb, bár nem tökéletesen ép példány: B. KovÁcs 2002: Abb. 14-16; és a településen, temetkezésekben feltárt lelet Aljmaš-on, állatcsontváz mellett: Grammenos 2003: 161). Balatonőszödön az „idolos" gödrökben néhány esetben más rituális tárgyak is előkerültek (pl. a 458. gödörben két épületmodelltöredék), illetve a gödrök környezetében levő további gödrökben találtunk más rituális jelenségeket: legtöbbször emberi és/vagy állati temetkezéseket, és egyéb rituális tárgyakat (összefoglalóan: HORVÁTH 2010). Ez alapján úgy vélem, hogy a településeken eltemetett emberek halotti szokásaihoz ugyanúgy hozzá tartozhatott az idolok használata és halotti mellékletként való adása, mint a szabályos, önálló temetők sírjainál (Včelince). A különbség annyi, hogy a településeken nem a halott mellé helyezték ezeket a tárgyakat. Egy másfajta, településen végzett halotti rítus mentén a temetkezési gödör környezetében található gödrökben lelhető fel a teljes temetési szertartásnak a halotthoz tartozó további kelléktára. További közös rítuselem mutatható ki a női idolok ábrázolása (végtagok csonkolása, fej hiánya) és a testtel való post mortem manipulációk között: az izolált csontok szintén a koponyához, és a végtagokhoz tartoztak a településen. A hiteles feltárási körülmények arról vallanak, hogy az esetek többségében egy hulladékgödörben egy idol- 
töredék található. Tökölön azonban egy gödörben 12 idolt tártak fel: ez az egy jelenségen belül előkerült leletek számának „lelőhely-csúcstartója” (KALıcz 2002), valóságos „idol-temető”.

A badeni idolok kialakítása teljességgel eltér a Kárpát-medencében megszokott korábbi idol-típusoktól, és csak annyiban viszi tovább a középső rézkor végi ill. az előtti neolitikus tradíciókat, hogy nőket, esetenként zsírfarú nőket ábrázol (2. Tábla: 1-2). A fej hiánya ill. cserélhetősége elsőként a késő Vinča kultúra Liubcován/Alsólupkón előkerült szobrában fejeződik ki (HoRvÁth 2010a: 118-119) (2. Tábla: 4). A formaijelentésbeli hasonlóságot eláruló leletek többségét a Balkánról, közelebbről Thesszália területéről ismerjük (2. Tábla: 5), az ottani Dimini-Rachmani kultúrákból (Thessalian Final Neolithic), amely a Kárpát-medencei középső rézkor vége időszakkal lenne párhuzamos. AŠošari-Sač nevű halomsírban a Cernavodă III kultúra leletei közt is találtak egy ilyen idol-torzót: ez jelentené az idol térbeli és időbeli utazásának utolsó láncszemét és közvetlen kapcsolódását a Baden-komplexumhoz (Govedarica 1997: 151, Abb. 4: 8). Ez lenne a Baden tipikus idol kialakulásának és egyik fontos rítuselemének geográfiai és kulturális/kronológiai előzménye. A Cernavodă III kultúra 3350-3100 BC közt a már retardáló Bolerázzal és a kialakuló Badennel is kapcsolódást mutathat a térségben (HORVÁTH 2009: 108-109).

$A z$ idol-típus elterjedésének érdekessége, hogy a keleti idegen paraszti és nomád kevert kultúrákba is eljut (bár észak felé, saját kultúrkörén belül nem terjed annak északnyugati határáig). A Jurij Rassamakin által Serezlievka-típusnak nevezett idolok (28 db) 12 kurgántemetkezésből láttak napvilágot a Dnyeper és a Dél-Bug folyók közt, egy pedig a késő Tripolje Sandraki településén került elő. Az ún. Dnyeper-Bug csoport helyi késő eneolit kultúra, amely Nižnemikhailovka, Kvityana és késő Tripolje elemekböl áll (RASSAMAKIN 2004: 81, Abb. 64: 1-2).

A női, mozgatható fejü idol-típuson kívül azonban a Baden kultúrának vannak atipikus idoljai is. Ezek közt a fenti típus al-variánsai a hasonló lapos kivitelben és megoldásokkal készült férfit (Cernavodă: 2. Tábla: 3; Satu Nou: Kalicz 2002: Abb. 22: 5, 7) és meghatározhatatlan nemü, esetleg hermafroditát (Branč: NovotNÝ 1981: Abb. 2: 7; Balatonszemes-Szemesi-berek: BONDÁR 2008: Fig. 2: 6; Balatonőszöd: HoRvÁTH 2010: 81 , Abb. 2) ábrázoló plasztikák. Ezek a ritka darabok a női termékenység-kultuszok mellett a férfi-társaságok, férfi beavatási szertartások egymás mellett élésére utalhatnak (további férfi-idolok: HoRVÁTH 2004: 204).

Ezen kívül azonban miniatür térplasztikák is előfordulnak (Vel'ka Lomnica: Novotný 1981: Abb. 2: 6; Balatonőszöd: HoRvÁTH 2010: 80, Abb. 1; Včelince: B. KovÁcs 2002: 21, Abb. 14-16; Krásno: BondÁR 19992000: Abb. 2: 5). Érdekességük, hogy van fejük, sőt, a Včelincén előkerült lelet feltehetően diadémot visel (vö. Vörs, BANNER 1956: 111, Taf. 87. 4, 8; HORVÁtH 2008: 162, 183-184). Nemük azonban kérdéses, hasonlóan, mint a vörsi diadémot viselő csontvázas egyéné (férfi, nő, vagy hermafordita?) (6. Tábla: 2).
Ma mintegy 130 idolt ismerünk a Baden kultúrából, kb. 55 lelőhelyről. A kutatás további feladatok előtt áll a már publikált, de hiányos közlések miatt. A leletek nagy része valóban szórványként került elő, sok pedig, ha hiteles ásatásból is, mégis annyira rosszul dokumentált, hogy ma már ellenőrzéssel sem tudunk többet kideríteni. Ezért a néhány jól dokumentált lelőhelyre és a továbbiakban előkerülőkre vagy publikálandókra kell koncentrálnunk. A jövőbeni közléseknek az alábbi hiányosságokat kell pótolniuk: a leletek teljes, minden részletre (pl. anyag, soványítás, égetés, készítési technológia) kiterjedő leírása és képi ábrázolása (méret, kiegészítés és keresztmetszet fotón és rajzon egyaránt!); a jelenség és a benne található leletek további leírása; a jelenség környezetének részletes leírása; a lelőhely igényes bemutatása (települési jelenség, település-temetkezés, temetőben sír, izolált lelet/jelenség); a Boleráz és a Baden ill. más, korábban post-badeninek nevezett kultúrák a lelőhelyen belüli elkülönítése.

A Kostolác kultúrából sem Magyarországról, sem a déli elterjedési területről nem ismerünk bizonyosan a kultúrába tartozó idolt, talán a Baden-KostolácVučedol rétegződés feltárási komplikációi miatt. Bizonyosan a kultúra emberábrázolásai közé tartozik viszont a korábban más időszakokba és kultúrákba sorolt Szelevény-Vadason elökerült edény a kultúra más, hasonló négyszögletes edényanalógiái nyomán, amelyeken viszont nem látható emberi ábrázolás (HoRVÁth-BALEN 2012). Ez a lelet azért jelentős számunkra, mert egyike azon legkorábbi leleteknek a már említett tököli idolon látható bekarcolás mellett, és más, hasonló korú európai leleteken látható ábrázolásokkal együtt (Bronocice: kocsi-ábrázolás edényen, tabée 4: 3; Val Camonica: térkép sziklarajzon, 4. Tábla: 4; Feldmeilen-Vorderfeld: térkép szövőszéknehezéken, 4. Tábla: 5), amelyeken a késő rézkorban megjelenő újszerű emberi környezet- és tér-elképzelések és maga a környezet-ember kapcsolat kifejezésre jut. Az egymás felé csúcsával fordított háromszögekből képzett emberi test és az adoráns kartartás jól harmonizál a Vučedol kultúra edényeken látható emberábrázolásaival (4. Tábla: 2).

A Vučedol kultúrából többfajta idolt ismerünk, és bekarcolt, edényeken megjelenő emberábrázolásai is előfordulnak (pl. DuRMAN 1988: Kat. 29, 33, 34, 35, 36; HoRváth-Balen 2012: Fig. 2) (4. Tábla: 2). A lapos idolokon lekerekített vonalakkal ugyan, de a Baden tipikus idoljaira jellemző fej és végtagok hiánya, a ruhadarabok, és a mellszalag ábrázolása folytatódik (DURMAN 1988: Cat. 33, 75) (8. Tábla: 5). Az idolok másik része háromdimenziós térplasztika, amelyen középen záródó, feltehetően hímzett díszítésű kaftánt ábrázoltak, karjai itt is csonkák, lábak helyett inkább harangszerü ruha-végződéssel, amely az al-dunai középső bronzkori idolokon is megfigyelhető (8. Tábla: 4, 6). A test kialakításában az edényábrázolásokon is látható egymás felé fordított háromszögekből képzett testfelépítés a kanonikus, amelyben A. Durman az Orion csillagkép fö alakját, Oriont, a Vadászt ismeri fel. Az idoltípusnak 

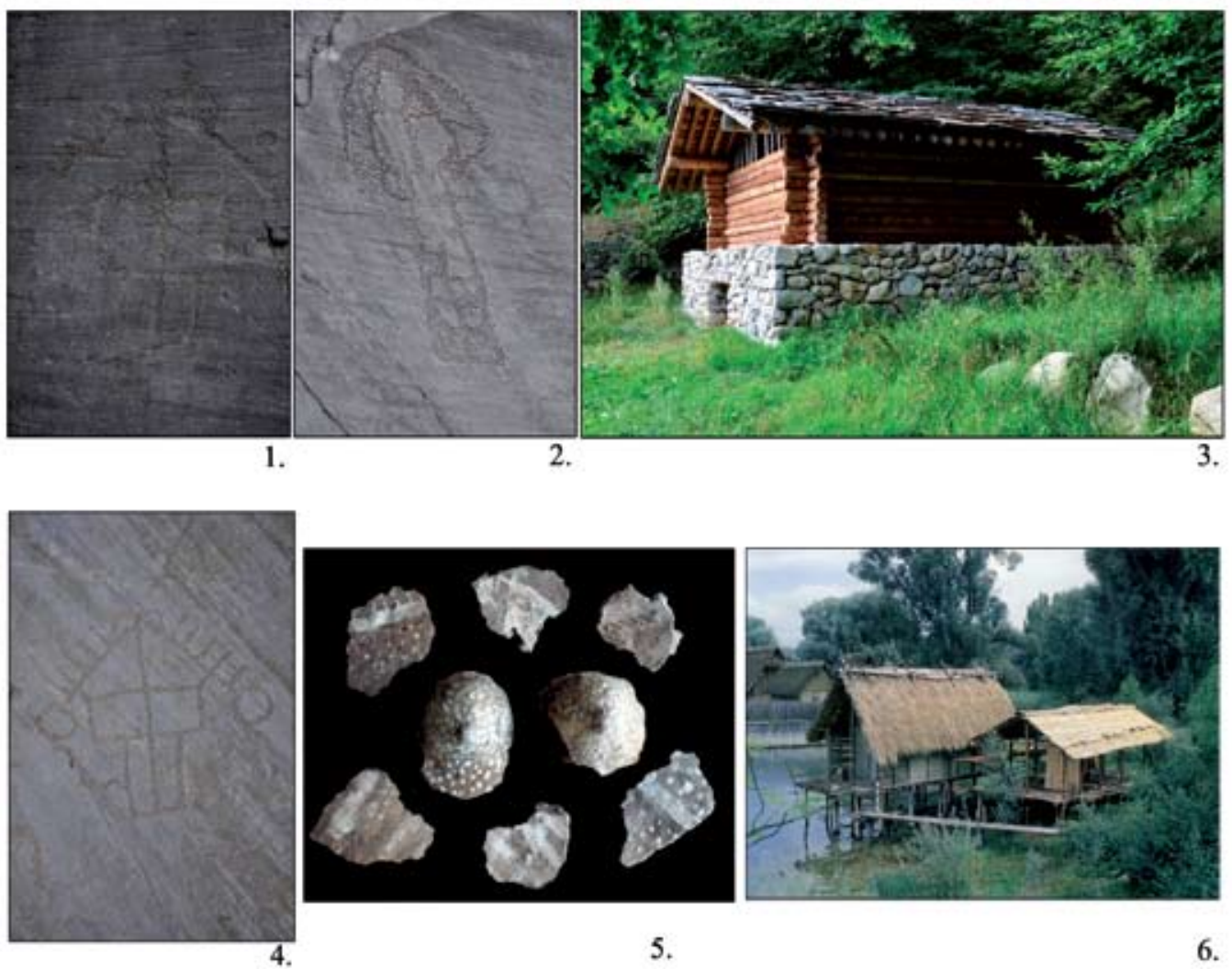

4.

5.

6.

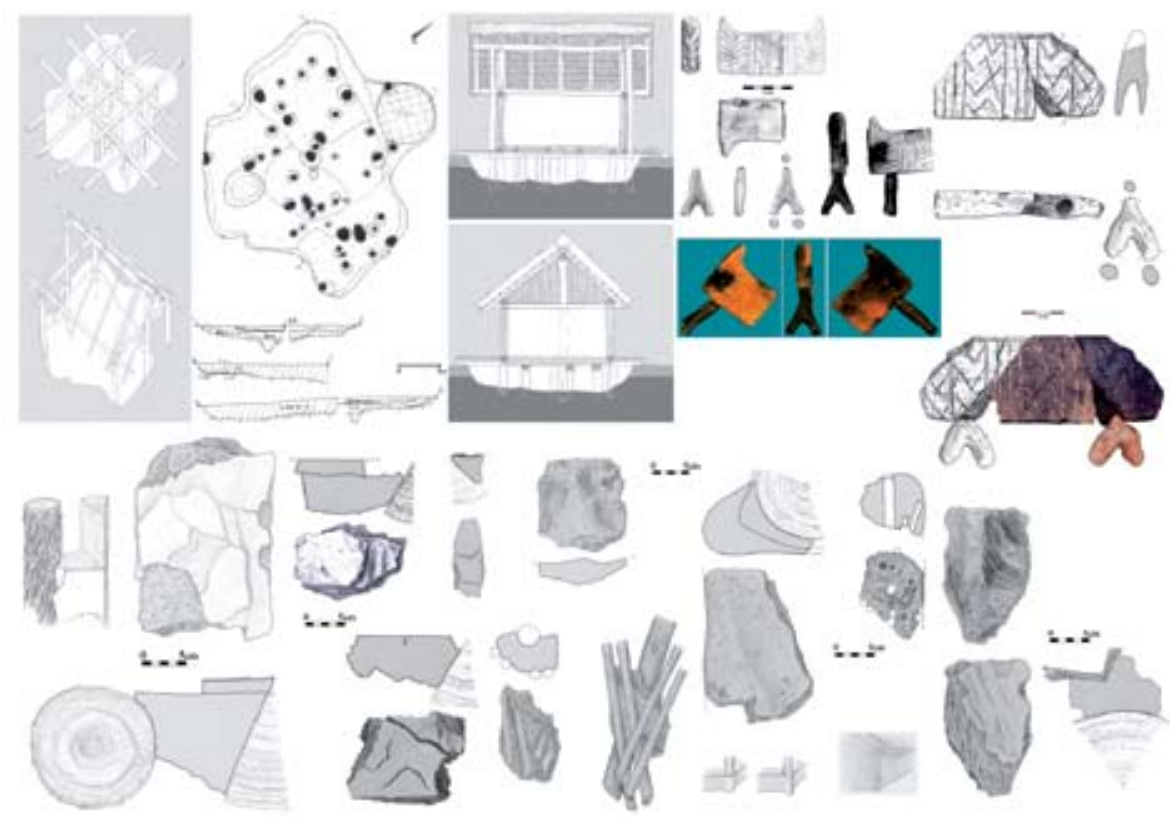

7.

5. Tábla: 1-2. Stelzbau-k ábrázolása sziklavéseten, Val Camonica. 3. Az épületek rekonstruckiója, Val Camonica Régészeti park. 4. Pfahlbau ábrázolása sziklavéseten, Val Camonica. 5. Fehérrel festett és plasztikus melltapasztással díszített ház-vakolat darabok Ludwigshafen lelőhelyröl Schlichtherle 2010: 267. után. 6. Pfahlbau típusú ház rekonstrukcója, Pfahlbaumuseum Unteruhldingen, Leuzinger 2000: Abb. 261. után. 7. BalatonőszödTemetöi-dülö: Pfahlbau típusú épületekre utaló jelenségek és leletek: ház alaprajza és rekonstrukciója, cölöplábas épületmodellek, háztapasztás-vakolatok. 


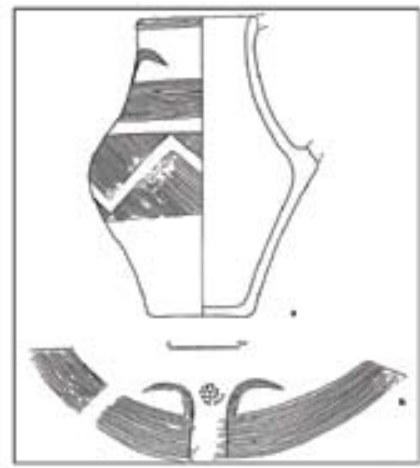

1.

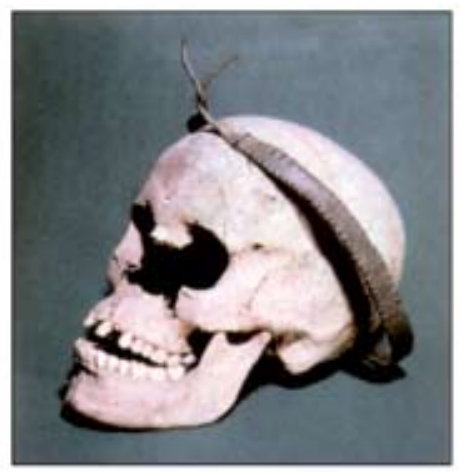

2.
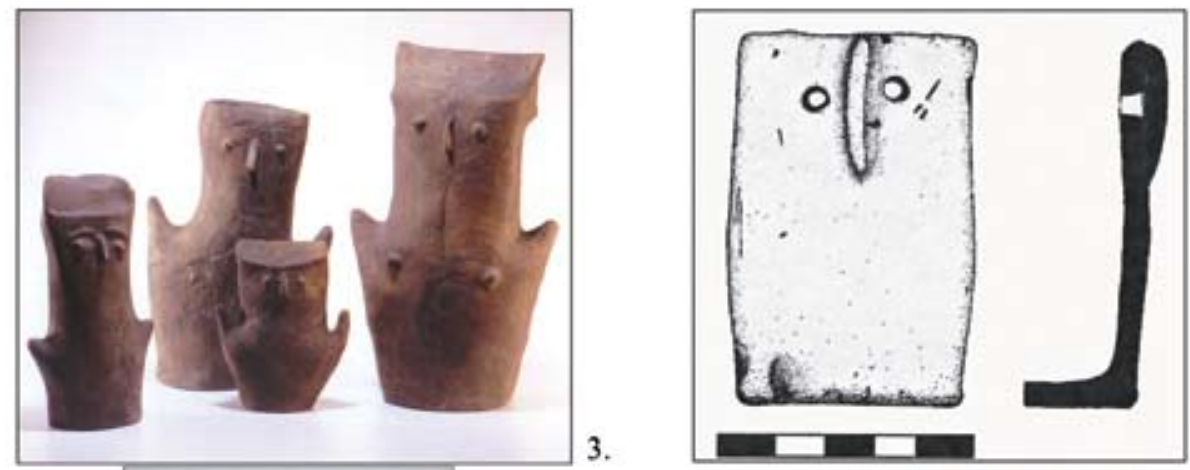

4.
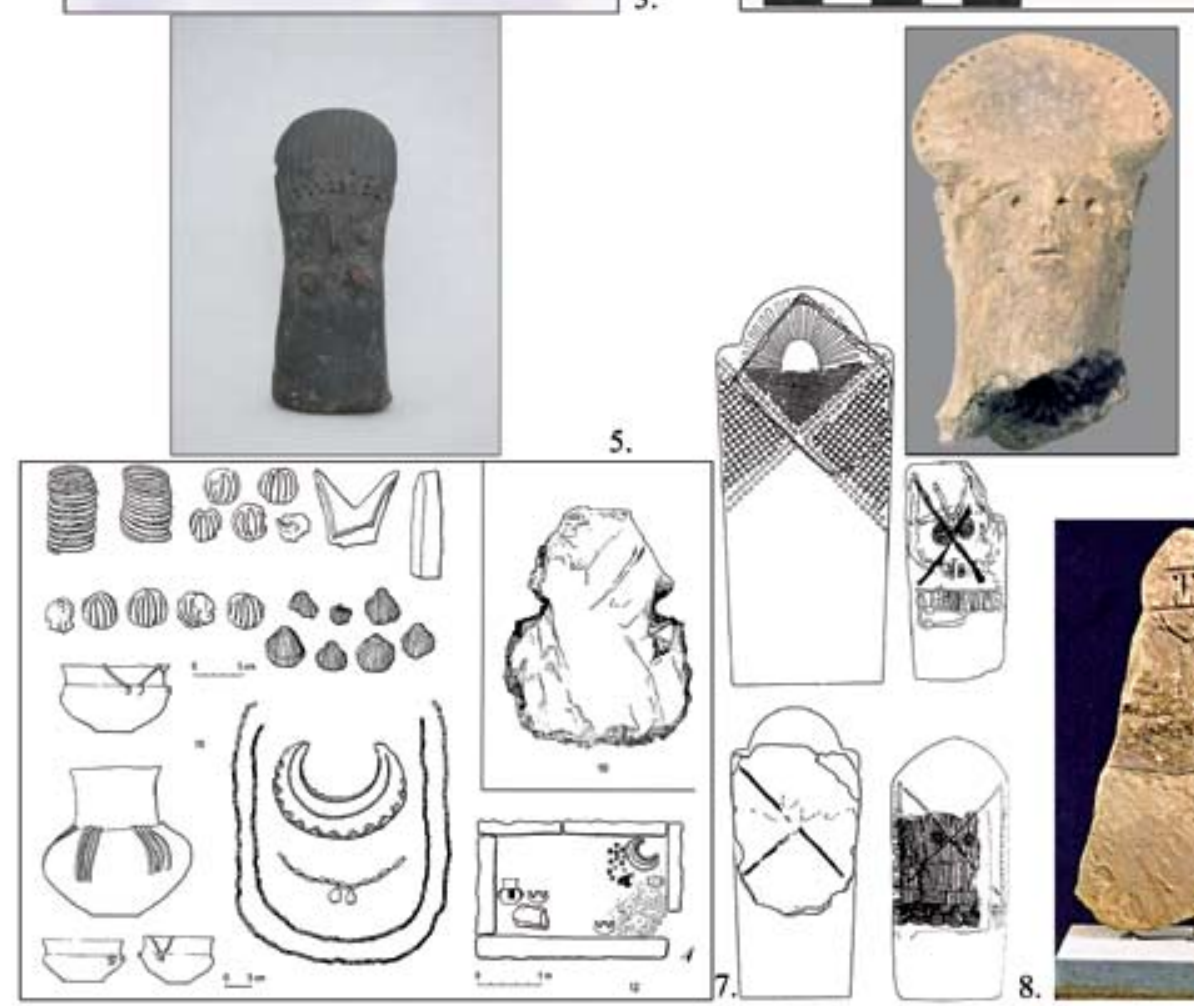

6.

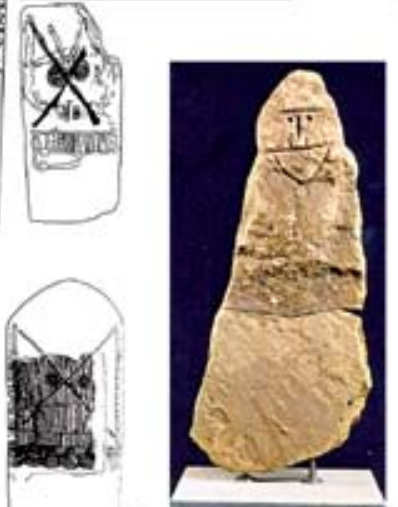

8.

9.

6. Tábla. 1. Bátaszék-Dolina-puszta, korsó diadém-ábrázolással a középső rézkor vége időszakból, Bondár 1998: Abb. 3. után. 2. Vörs. Emberi fej réz diadémmal. Visy 2003: 123. után. 3. Ózd-Center, antropomorf urnák, Visy 2003: 136. után. 4. Debrecen-Köntös-kert, miniatür emberarc-ábrázolásos pohárka Makó urnasírból, Németi-Dani 2001: 9. kép: 1 után. 5. Méhi-Feketesár dülő. Női idol. (A tárgy leltári száma: A 2369. Fotó: GömörKishonti Múzeum, fotó: Júlia Ferletáková, B. Kovács István engedélyével) 6. Kőérberek-Tóváros-Lakópark, Makó idoltöredék, Zsidi 2005: 84. után. 7. Velvary és Stehelčeves, köládás sírok és sírmellékletek Neustupný 2013. Fig. 28: 11-12. után. 8. Mellszalagot viselő sztélék és menhírek a késő rézkor időszakából Schlichtherle 2010: 274. után (Aosta, Sion, Latsch lelöhelyekröl). 9. A Velvary sírban feltárt réz pektoráléhoz hasonló mellékszert viselö sztélé Rottenburgból, Lichter 2010: 265. után. 
azonban van feje, és a neolitikumtól szokásos kerek, maszkszerü fej-ábrázolás helyett ezúttal sematikus, hosszúkás arcábrázolással (DURMAN 1988: Cat. 34, 76; Durman 2000).

A térben a Badennel szomszédos, vele egyidős Coţofeni kultúrában idolok előfordulnak ugyan, de kerek, maszkszerü, felfelé forduló fejjel kialakítva, tehát nem a badeni fő-típust követik (RışCUŢA 1996). Néhány díszítetlen mellett a kultúrára jellemző beszurkált (ruhában látható) díszítésü darabok is elökerültek.

\subsection{Kora bronzkor}

A Baden kultúra $2800 \mathrm{BC}$ utáni továbbélése szempontjából érdemes egy pillantást vetni a hagyományos kora bronzkori besorolású magyarországi Makó és Somogyvár-Vinkovci kultúrák idoljaira (KULCSÁR 2009: 164-166, 339-343), amelyek szintén nem emlékeztetnek a tipikus Baden idolokra. Van azonban a Makó kultúrának egy atipikus női idolfej-torzója, amely magas, félköríves, körben poncolt diadémjával éppen a legjobb formai párhuzama a včelincei sírban előkerült idolnak (Kőérberek-Tóváros-Lakópark, ZsıDI 2005: 84) (6. Tábla: 5-6). A kora bronzkorban egymás mellett vagy együtt élő Baden és Makó kultúrák (DANI-HoRVÁTH 2012: Figs 2-3) rituális hagyatékában tehát az idolok között van közös vonás, bár nem a tipikus rituális „tömegáru” között kell keresnünk.

\section{4. Összegzés}

A Baden lapos, mozgatható fejü női idolok kultúraspecifikusak: csak a Baden kultúrában fordulnak elö, és nem tipikusak a Magyarországon a Baden-komplexum részét alkotó Boleráz, Kostolác, Vučedol kultúrákban, sem a szomszédos és egyidős, feltételezések szerint rokon (?) Coţofeni kultúrában. A Kárpát-medence területén előzmény nélkül jelennek meg, kapcsolatrendszerük alapján észak-balkáni területről és örökséggel, és a badeni kultúrára jellemző módon közel-keleti-mediterrán idol-tradíciókat mutatnak (vö. HANSEN 2001) (2. Tábla: 5). Kisugárzási területük a keleti steppék felé a Gödörsíros kurgánok és a Baden-komplexum közös kapcsolataira, együttélésére utal (HORVÁTH 2011).

\section{Agyagművesség: maszk}

\subsection{Neolitikus előzmények}

Az európai maszkviselet a neolitikumtól kezdve levantei-anatóliai-mediterrán hatásokat és gyökereket mutat, az idol-használathoz hasonlóan (HANSEN 2001). A legtöbb álarc-ábrázolás ezért, nem meglepő módon idolokon (vö. HANSEN 2007), ritkábban más leleteken (pl. edényeken: vö. SchwARZBERg 2010), jelenségeken (pl. épületfalakon: Uivar/Újvár) található.

Önálló, neolitikusnak tartott agyag álarc-leletek korszakos és kulturális besorolása bizonytalan a nem hiteles előkerülések miatt (Siefersheim, Worms, Sechelbach, vö. HoRVÁTH 2004: 209-210, Fig. 14: 1, 2, 3: talán inkább késő bronzkoriak, vö. MARASzEK 2010). Egyedül az Uivar lelőhelyű Vinča lelet stabil ebből a szempontból (SCHIER 2010). Vannak azonban olyan leletek, amelyek a közel-keleti agyagtapasztásos koponya-kompozíciókhoz hasonló post mortem maszkos halottkultuszra látszanak utalni Európa területén (pl. a Vonaldíszes kultúra Eilsleben-i; a Chasséen kultúra Jonquières-i; és a Funnel Beaker/Corded Ware Dümmer nevü lelöhelyén: TEEgEn 2010).

A maszk-használat a neolitikum után a kora és középső rézkor folyamán szakadást mutat Magyarország területén az idol-ábrázolást tekintve. Néhány, biztosan fejjel (és nem nyakkal vagy nem egyértelmü nyúlványnyal) ábrázolt idol arca annyira sematikus, hogy akár maszkként is magyarázható (pl. a tiszafüredi Hunyadihalom lelet) - bár egyértelmüen nem bizonyítható.

Bizonyos szintű túlélést képviselnek azok a sírok, ahol magán az eltemetett egyeden figyeltek meg szerves anyagtól származó elszíneződést, amelyet maszkírozásnak/maszk-viseletnek tartanak (Tiszai kultúra, késői neolitikum: Čičarovce/Csicser: VizDAL 1980, mezolitikumtól elözményekkel, vö. FLoss 2010, 56-57; Várna kultúra, középső rézkor, Varna: 2, 3, 15. jelképes sírok fejmaszk-tapasztással, HoRvÁTH 2010a: 121-122; BERTEMES 2010). Talán álarcot vagy fejfedőt (sisakot) viselő férfi látható egy „arcos” korsón (BondÁR 1998). Véleményem szerint a Bátaszék-Dolina-pusztai korsó a Furchenstichhel kevert középső rézkor végi horizontba tartozik, és a kompozíció diadémot ábrázol, amelynek legközelebbi formai és idöbeli párhuzama a Vörsön feltárt késő rézkori csontvázas sír réz diadémája (BANner 1956: 111) (6. Tábla: 1-2).

\subsection{Késő rézkori álarc: egyedi lelet?}

Ilyen előzmények után a balatonőszödi feltáráson előkerült, badeni kultúrába sorolható félbetört állapotú agyag férfi-álarc valóban meglepetést okozott. Egy ilyen lelet felbukkanása a késő rézkori Badenkomplexumon belül előzmény nélküli volt. A leletet bemutató és értelmező eddig megjelent írásaimnak (HoRVÁth 2002, 2002a, 2002b, 2004, 2010, 2010a, 2011a) rövid esszenciájaként az alábbi értékelést adhatjuk róla.

A lelet hiteles körülmények közt került elő: egy amorf gödörbe ásott későbbi, négyszögletes objektum tetején feküdt, amelyet a még későbbi kultúrréteg befedett. Ezt a rétegzettségi sorrendet és az időszakokhoz rendelt „normális” abszolút koradatokat a jelenségből és a leletekből készült radiokarbon és TL-OSL dátumok is alátámasztják. A lelet a négyszögletes gödör tetején, arccal felfelé feküdt (orra emiatt meg is sérült a feltárás alatt). A komplex jelenség-értelmezés lehetővé teszi, hogy a kettős beásást akár jelképes sírként értékeljük. Hasonló körülményeket írtak le az afrikai déli Pangwé-k közt férfivá avatási szertartáson.

Ha viszont a jelenség tágabb környezetét is bevonjuk az értelmezésbe, további alternatív szerepköröket találunk az álarc-viselethez. A szomszédos jelenség egy juh-áldozati gödör volt nagyon közeli radiokarbon dátummal, és egy komplett szertartási térrel, amelyhez tüz- és hamuzó-helyek tartoztak: az álarcot viselhették az állat-áldozat bemutatása közben is (1036. gödör és környezete). Vannak a környezetében emberi és álla- 
ti temetkezések is, és gödrök más rituális tárgyakkal (idol: 1088. gödör, épületmodell: szomszédos szelvényt fedő kultúrréteg), valamint épületek (20, 22, 23. házak), amelyek kapcsán felmerül a maszk esetleges épület-alapító-áldozatként való értelmezése, de házat díszítő, berendező, vagy védő szerepe is.

Önmagában véve a legesélyesebb értelmezés az, ha a tárgynak eleve több funkciót tulajdonítunk élete különböző állomásai során, hiszen az eredeti, elsődleges funkciója (emberi viselet vagy más, pl. házdísz, kultikus ház berendezése) már önmagában eltérő lehetett, mint a megtalálásakor rögzített törött, másodlagos funkciója (talán egyszerü hulladék; talán mégis funkcionális szerepben: Ös, egy férfi-korosztályt megszemélyesítő ember, stb.).

A maszkokat egyébként is csoportosítani szokták, ám a leghagyományosabb felosztásban is az őskorban ezek a funkciók még biztosan nem váltak szét egymástól, tehát minden őskori maszk egyszerre látott el rituális, halotti és akár színházi szerepet is, ezeket a feladatköröket tág értelemben, őskori szokások közt értelmezve (pl. egy áldozat-bemutatáson viselt maszk lehet egyszerre rituális és színházi is, ha elfogadjuk a rítust egyfajta őskori, közösség előtti szakrális színházi fellépésnek).

Ugyanakkor ki kell emelni néhány olyan sajátosságot, amely a balatonőszödi leletet megkülönbözteti más őskori európai agyagmaszkoktól. Az egyik érdekesség, hogy viseletnek nincs jól látható, elváltozást hagyott nyoma rajta. Érvelhetünk azzal, hogy mert csak egyszer vagy ritkán használták, de lehet ennek köze valódi szerepéhez is: vagyis hogy pl. épületen belül, falon vagy egy szentélysarokban volt felfüggesztve, mint Ős vagy a közösség vezetője, ezért keveset érintkezett emberekkel.

A másik a lelet 1:1-es, realisztikus megformálása, amely mind fizikai megjelenésében, mind pedig szimbolikus jelentésében nem volt jellemzője korábbi és későbbi őskori társadalmaknak sem. Az emberábrázolás lényege az őskorban a sematikusságon keresztül kifejeződő közösségi fajfenntartás. A családi vérvonalak (klánok, ágazatok, nagycsaládok, stb.), ezen keresztül tehát a közösség fennmaradását voltak hivatva kifejezni, nem pedig egyes személyeket reprezentáltak, kiemelve egyéni tulajdonságaikat, kiválóságukat (ez a szempont érvényesül még a jóval későbbi agyagmaszkokon is, pl. Ostrov és Middelstrum esetében). (Vö. még a névadási szokások, a beavatási szertartások és a titkos társaságok összefüggéséröl, amely az egyéniség kifejezésére szolgálhat: COHEN 1992). Ehhez képest a balatonőszödi lelet annyira részlet-gazdag, hogy antropológiai rekonstrukcióra is alkalmas. Portrészerü megformázása, valamint az, hogy férfit ábrázol egy túlnyomórészt nőket felvonultató badeni rituális színházi kelléktárban, kiemeli nemcsak a Baden, hanem az előtte, és talán az utána következő őskori világokból is (a későbbi, előbb felsorolt önálló ostovi és middelstrumi agyagmaszkok már egyértelműen férfit ábrázolnak, bár azok is sematikusan!).

Valóban a késő rézkor korszaka az első olyan régészeti kor, amelyben az ember megpróbálja a saját képére formálni a világot, és ennek az erőfeszítésnek még számunkra is látható nyomait adja 5000 évvel később fennmaradt különböző ábrázolásokban (ld. fentebb, az idoloknál a szelevényi edény kapcsán sorolt példákat). A mentális kép kivetítésének (térkép-alkotás) fejlődésében tulajdonképpen logikus, hogy nemcsak a táj kap emberléptékű formázást és dimenziókat, hanem benne az ember is más megvilágításba kerül: a karizmatikus egyéniségekre fókuszál, és őket már a saját társadalmukból kiemelkedő individuumokként, akár személyiségjegyekkel ábrázolja. Bár ez még nem egy öröklött státusz, és nem rangsoroló társadalom, de láthatóan megkezdődhetett egyfajta társadalmi tagozódás, specializálódás.

A balatonőszödi leletben egy a Baden-komplexumra antropológiailag kevéssé (kb. 20\%-ban a sírok embertani anyaga alapján) jellemző cro-magnoni embertípust rekonstruáltunk, akinek egyik al-variánsa a keleti steppékről (vö. Gödörsíros kurgánok vagy CucuteniTripolje és Baden kapcsolatok, vö. VIDEIKO 2000), másik al-variánsa az alpi-dinári embertani típussal a tóparti települések irányából ismert. Utóbbit azért tartjuk kevésbé valószínünek (de nem teljesen kizártnak), mert a maszk egyértelmüen badeni és nem bolerázi a településünkön, míg a tóparti települések-cirkumalpi kapcsolatok jobbára a Bolerázhoz, és csak kisebb mértékben a Badenhez köthetők. Semmit sem tudunk azonban ennek a férfinak a balatonőszödi közösségen belüli társadalmi státuszáról: idegen vagy a közösséghez tartozó volt-e (tehát badeni vagy esetleg bolerázi vagy Gödörsríos kurgán?); közrendbeli, alacsony- ill. magasrangú-e (rabszolga vagy vezető), társadalmi, katonai vagy vallási (vagy mindhárom) szereppel?

Ugyancsak szólnom kell röviden a lelet modern sorsának alakulásáról is (7. Tábla), mivel - mint például az igazi „nagy” könyveknek, daloknak, verseknek - a különleges régészeti leleteknek is önálló életük, saját útjuk van. Ennek a leletnek az újra-felfedezése, előkerülése után különleges, mondhatni mostoha sors adatott, nem önhibájából, és még csak nem is a feltáró-feldolgozó régész hibájából.

A Húsvét előtti Nagypénteken előkerült leletet a Régészeti Intézet határozott kérésére azonnal be kellett mutatnom egy népszerüsítő tudományos folyóiratban (ÉLET És TUdOMÁNY). Nem szeretném túl-körvonalazni azokat a nehézségeket, amelyeket akkor bronzkori kövekkel foglalkozó doktorandusz régészként, az ásatáson 10 órát, majd az ásatás után a napló számítógépes rögzítésével és egyéb szervezési apróságokkal további órákat töltő fáradozás után, könyvtár és anyagismeret nélkül éreztem a feladat közben, amellett, hogy egy egyedi tárgyat kellett kezdő régészként, nyilván nem akármilyen elvárási színvonalon bemutatnom. Az első cikk ettől függetlenül az ÉLET És TudomÁNY júniusi első számában megjelent (HoRVÁTH 2002), azaz egy hónap alatt eleget tettem a kívánalmaknak. Ez inkább volt részemről kulturális antropológiai megközelítés, mint régészeti, mivel ahhoz közelebb állónak éreztem magam és a felkészültségem. Továbbá a lelet bekerült az éppen szerkesztésben levő MAGYAR RÉGÉSZET AZ EZREDFORDULón c. kötet megfelelő fejezetébe (VISY 
2003: 135, Fig. 26), az intézeti évkönyv (ANTAEUs) aktuális 25. számába (HORVÁTH 2002a), valamint az ŐsRÉGÉSZETI TÁRSASÁG folyóiratába (ÖSRÉGÉSZETI LEVELEK 4: HORVÁTH 2002b) - vagyis ismertté vált a tudományos és érdeklődő közélet számára. Meg kell jegyeznem, hogy ez a fajta út nem szokványos a magyar ősrégészetben, ahol az igazi, érdekes és egyedi tárgyak közlésére gyakran évtizedekig kell várni, sokszor hiába. A kezdeti gyors befutást a saját, már bizonyosfajta tudományos komplexitásra törekvő kezdeményezésem követte (HoRVÁTH 2004), a soron következő állomás pedig az M7 autópálya-ásatások bemutatása volt egy Kaposváron rendezett konferencia, kiállítás, és az ezt tárgyaló kötet kapcsán 2007-ben (HORVÁTH 2007). Tulajdonképpen nem lehetne okunk (sem Nekem, sem a Leletnek, akit itt már „megszemélyesítek”, mivel akarva-akaratlanul önálló életre kelt) sem panaszra, sem szomorúságra, ha a jól megérdemelt és sikeres közszereplés után a Lelet - és vele én is - „felejtésbe” merültünk volna, hiszen éppen eleget szerepeltünk már. Csakhogy nem ez történt, de ennek ellenkezője sem: további emelkedésröl sem tudok beszámolni.

Innen vettek rossz fordulatot a dolgok, és feltehetően inkább emberi hibából kifolyólag, nem szakmai tévedésből. Valójában az ÉLET És TUDOMÁNY külön-melléklete, az ÖSRÉGÉSZETI LEVELEK és a GÖRDÜLÖ IDŐ borítóján való szerepeltetés és a Leletnek kijáró vagy nem kijáró „reflektorfény”, ill. engem illetően pedig a cikkek megfelelő színvonala és tudomásul vétele után furcsa és érthetetlen volt, hogy egy ilyen egyedi és az ország, valamint az emberiség számára „közkincsként” definiálható lelet nem kerül fel a Magyar Nemzeti Múzeum állandó őskori kiállítására, amelyet éppen ekkor rendeztek újjá (2002. november 25.-én nyílt meg).

Így a Kaposváron rövid ideig látható 2007-es kiállítás után a Lelet nem kapta meg az őt illető helyet, nem szerepelt nagy nyilvánosság előtt, nem látható bárki számára bármikor, és méltatlanul, elfeledve hever egy Kaposvár külvárosában található raktárban. Nemzetközi téren, a Balatonőszöd után Uivar-on elökerült újabb hiteles álarclelet karrierjéhez kapcsolódóan egy konferencián szerepelt Halléban (HORVÁTH 2010a). Egyszer pedig még, véletlen- és alkalomszerüen, a debreceni Déri Múzeum kérésére eljutott 2010-ben a MúzEUMOK ÉJSZAKÁJA elnevezésű egy éjszakás rendezvényre (és ez az „egy éjszakás-kaland” rekord-bevételt jelentett a múzeumnak a maga 5500 fös látogatójával azon a június 20.-ai éjjelen: ilyen rekordbevétel még a fővárosi közkedvelt és látogatott múzeumoknak sem adatott meg korábban).

Már ekkor azonban furcsa híresztelések indultak meg a Lelet korát és a tudományos felkészültségemet illetően, olyan vádakkal, amelyek nem szakmai, ellenörzött fórumokon (pl. konferenciákon, publikációkban, recenzióban vagy kritikában) hangzottak el. Ezért nem lehetett hitelesen és tudományosan reagálni rájuk sem számonkérés (pletykára szakmai fórumon nem lehet reagálni, mivel nem ismert, lenyomozható, hiteles forrásból származik, a hétköznapi életben pedig azért nem tudtam, mert nem vagyok ilyen alkat), sem tilta- kozás vagy védekezés formájában. Céljukat azonban ily módon még tökéletesebben és még nagyobb romboló hatással elérték (hasonló megtörtént dokumentált esetek a tudományos világban pl. BROoKs 2011).

Valójában sokáig nem is éreztem szükségesnek semmiféle reakciót. Úgy gondoltam, hogy az eddigi munkám a mérleg egyik serpenyőjében sikeresen fogja ellensúlyozni az alaptalan és tudománytalan rágalmakkal teli másik serpenyőt, és a tudományos szakma áll olyan intelligens kutatókból és kiváló emberekből, akik előbbiek ismeretében levonják az egyértelmü tanulságot maguktól is, anélkül, hogy beavatkoznék. Ebbéli hitem akkor rendült meg, amikor saját munkahelyem, az MTA Régészeti Intézete hivatalos 50 . évfordulójára készülvén rendre kihagyott az ünneplés-sorozat minden állomásából, mind személyemet, mind a leletet és a lelőhelyet illetően (DARÁzsy 2010: 112-113). Beláttam, hogy rossz taktikát választottam, mert nem számoltam a „kisemberek” befolyásolhatóságával, a fentről jövő engedelmesség túlélő kultuszával egy fiatal demokráciában, a hatalom nyomásával és autokráciájával, amely a tudományban is érvényesül, és az emberek felkészületlenségével, önállótlanságával, rosszhiszemüségével.

Levonva a kellő konzekvenciát az egyetlen józan lépésnek az számított, ha bizonyítani tudom a maszk korát és kulturális hovatartozását, és minél hamarabb közzéteszem. Amennyire könnyü azonban kételkedni e kérdésben, legalább annyira nehéz tudományosan bebizonyítani. Ez a lelet - bár mind a Baden-komplexumban, mind az őskorban bizonyos fokon egyedinek számított - más tekintetben viszont tökéletesen illeszkedett a lelöhely badeni jelenségei és leletei közé: hitelesen badeni jelenségekben feküdt, jellege, anyaga, égetése, kialakítása, soványítása teljesen megegyezett a több ezer hasonló badeni lelettel a lelöhelyen, és az objektumból származó állatcsontból mért radiokarbon dátum is késő rézkori, Badenre jellemző „normál” értéktartományt mutatott. Ez azonban nem volt elegendő a mindenben szemfényvesztést látó örök kételkedőknek.

A cselekvési lehetőséget az jelentette, ha magából a tárgyból próbálunk kort mérni, és az már biztosan és egyértelmüen a lelet korát jelenti, nem valamelyik jelenségét, vagy a jelenségekben található másik, esetleg bekeveredett leletet. Csakhogy a kerámiából való radiokarbon-méréseket még ma is alig néhány labor végzi, nagyon drága, és nem is megfelelő színvonalú a módszertani háttere. Anyagi nehézségek között (mivel nem terveztem azt a lépést, hogy a tárgy korát bizonyítanom kell majd természettudományos módszerekkel, erre vonatkozó költséget sem terveztem egyetlen pályázatba sem, amely a lelöhely feldolgozását érintette) a tárgyon és további, a kettős gödörböl és a felette levő kultúrrétegből származó kerámialeleteken, ill. a gödörből vett földmintán TL/OSL kormeghatározást végeztünk, amely egyértelműen alátámasztotta a már előzőleg körvonalazott korszaki és kulturális besorolást (HoRVÁtH et al. 2010; Sipos et al. 2012). A sikeres és most már cáfolhatatlan bizonyítás után sem történt 
azonban semmilyen lépés a Lelet életében: továbbra is raktárban porosodik, elfeledve. Helyreigazítás, bocsánatkérés helyett pedig a lelőhely és a feldolgozó régész élete, ha ez egyáltalán lehetséges, még nehezebb lett, mert ezek után még durvább diszkriminációval és kiközösítéssel sújtották.

\subsection{Maszkok a rézkor után}

Sem a hagyományosan kora bronzkori besorolású kultúrákban, sem a középső bronzkor időszakában nem került elő Magyarországon önálló maszk-lelet, semmilyen ábrázolási formában. Európa nagyobb területét vizsgálva sem tűnik másnak a kép: csak a késő bronzkor időszakától kezdődik újra a maszk-viselet (vö. HoRVÁTH 2004: 209-210, önálló agyagmaszkok Ostrov, késő bronzkor; Middelstum, kelta). A tiszai kultúra után újra felbukkan a mezolitikus reliktumú koponyásmaszk kultusz (Kyjatice kultúra, Katakomba kultúra), valamint a maszkok eredetileg óvó-védő/baj-elhárító szerepköre kibővül a fémmüvesség technológiájának fejlődésével egy új irányt kapva a védőfelszerelések részét képező, sisakokhoz tartozó arc-maszkok megjelenésével (Kleinkein, Trebenischte, stb., HORVÁTH 2004: 205-209; REICHENBERGER 2010).

\section{4. Összegzés}

Összességében elmondható, hogy bár a paleolitikumtól a vaskor végéig a maszk-használat számos formájával (önállóan, idolon, edényen, stb.) találkozunk, amelyből akár bizonyos kontinuitást is kiolvashatunk, bizonyos korokban Magyarország területén érdekes hiány vagy ür lép fel (kora és középső rézkor; kora és középső bronzkor), amelyröl egyelőre még nem világos, hogy egyszerü kutatási hiány-e, vagy pedig tényleges szakadás, amelynek oka megfelelő feltárási és publikálási feltételek teljesülése után a jövőben akár tudományosan is magyarázhatóvá válik.

Egészen 2002-ig a késő rézkor hosszú időszaka is ebbe a lelet-nélküli vákuumba tartozott, ez azonban, a magyar kutatók tudomásul vétele ellenére Balatonőszöddel mára megváltozott. $A z$ ürügyként felhozott pletykaszintű érv, hogy az ostrov-i lelet miatt a balatonőszödi is késő bronzkori lenne, egyszerűen nevetséges. Egyrészt azért, mert a harmadik, 2000 óta napvilágra került hiteles Uivar-i újabb lelet után akkor ugyanezen a logikai-analógiai úton felmerülhetne a lelet Vinča-datálása is - a Dunántúl ezen területén nem ismerünk ilyen kultúrát!

De hát a leleteket, még ha tényleg egyediek is, mint ez a maszk, nem ilyen módon szokták datálni! A balatonőszödi hatalmas kiterjedésű és feltárt lelőhelyen (több mint 3000 földbe ásott objektum, több százezer lelet) egyetlen neolit vagy késő bronzkori jelenség és lelet sem került elő. Bár a maszk egyedi tárgy, mégsem az égből pottyanhatott oda..., már csak azért sem, mert hiteles feltárási körülmények között találtuk, amelynek segítségével előkerülési körülményei éppen hogy hozzájárultak magasabb szintű értelmezéséhez, és nem a szórványleletek számát és a légből kapott érveléseket szaporították.
Ami a rézkor időszakának egy másik, már ilyen kevés hiteles megfigyelésből levonható fontos különbségének látszik a neolitikumhoz képest, hogy a maszkhasználat az idolokról az emberekre tevődik át, vagyis a holt anyagból az élők rituáléjának részévé, szerepjátszó kellékévé válik (a rituális-színházi szerepkör erősödik a halotti mellett).

\section{Agyagművesség: antropomorf vonásokkal felru- házott edények}

A kutatás szempontjából antropomorf vonásokkal (arccal, kezekkel vagy lábakkal, ill. keblekkel) felruházott edényeket tárgyaljuk ebben az alfejezetben.

Az antropomorf urnák „prototípusa” a Baden kultúra ózd-pilinyi csoportjának urnás-hamvasztásos temetőlelőhelyeihez kötődik (6. Tábla: 3,5$)$, más lelőhelyen nem fordult elő eddig: Ózd-Center-Kőfej-alja - 8 sír; Szentsimon-Kender-földek: - 2 sír; Sajógömör-Alsótábla/Gemer - 21 sír; Méhi-Feketesár-dülö/Včelince - 7 sír a Hangony folyócska mentén (HoRVÁTH 2004: 205). Az ábrázolások a négy lelőhelyről igen hasonlóak. Érdekességként kiemelhető értékelési szempontok a megformálásban a diadém-lezárású fej-végződés, a felemelt, adoráns tartásban levő karok, és a kerámia felületének seprüzése, amely a badeni kultúrára nem jellemző, a hagyományos kora bronzkori kultúrákban (pl. a Makó kultúrában) azonban nagyon jellegzetes. A férfi vagy női nemre az idolokhoz hasonlóan a melldudorok megléte ill. nem léte utal. Az arc két szem és egy orr plasztikus kialakításából áll, néha a szemöldök is megjelenik. Ennek a jelentéktelennek tűnő részletnek lehet igazi, fontos korabeli szerepe is. Az európai vagy nyugati modern társadalmakban általában a szem az arc azon része, ami a kommunikációban a legfontosabb kontaktusteremtő és kifejező szerepet játssza („a lélek tükre”). Más társadalmakban azonban, például az antik és a modern kínaiban, a szemöldököt tartják a belső érzések legnyilvánvalóbb kifejezőjének, és a boldogság metonimikus ábrázolásában a szemöldök szerepét hangsúlyozzák, nem a szemét (vö. ragyog a szeme a boldogságtól kínaiul a szemöldökkel). A szemöldök megjelenítése, tehát valamely fontos funkciójára valló felhívása lehet egy korabeli kommunikációs közvetítő-forma kifejeződése is (KöVECSEs 2005: 190). További figyelemreméltó aprólékos részletesség az egyik méhi edényen az arcban a nyelv feltüntetése (B. Kovács 2002: 21, Abb. 19-20, 1. sír, 6-7. edények; HoRVÁTH 2008: 160), amely talán egyfajta őskori „utalás" lehetett a megértés-egymás mellett élés-beszéd/ nyelvi nehézségek terén.

Az Ózd-Piliny csoport helyzete a Baden kultúrán belül mind kulturálisan, mind területileg, mind pedig kronológiáját tekintve kérdéses, és minden reális tényt nélkülöz. Sokáig a kultúra legidősebb csoportjának vélték, és egyúttal területi-földrajzi csoportként is számon tartották (BANNER 1956 óta). ÉK-Magyarország és Szlovákia szomszédos csatlakozó területe (Szepesség) valóban elkülönülni látszik leletanyagában a Baden kultúra más magyar területeitől. A leletek, elsősorban 


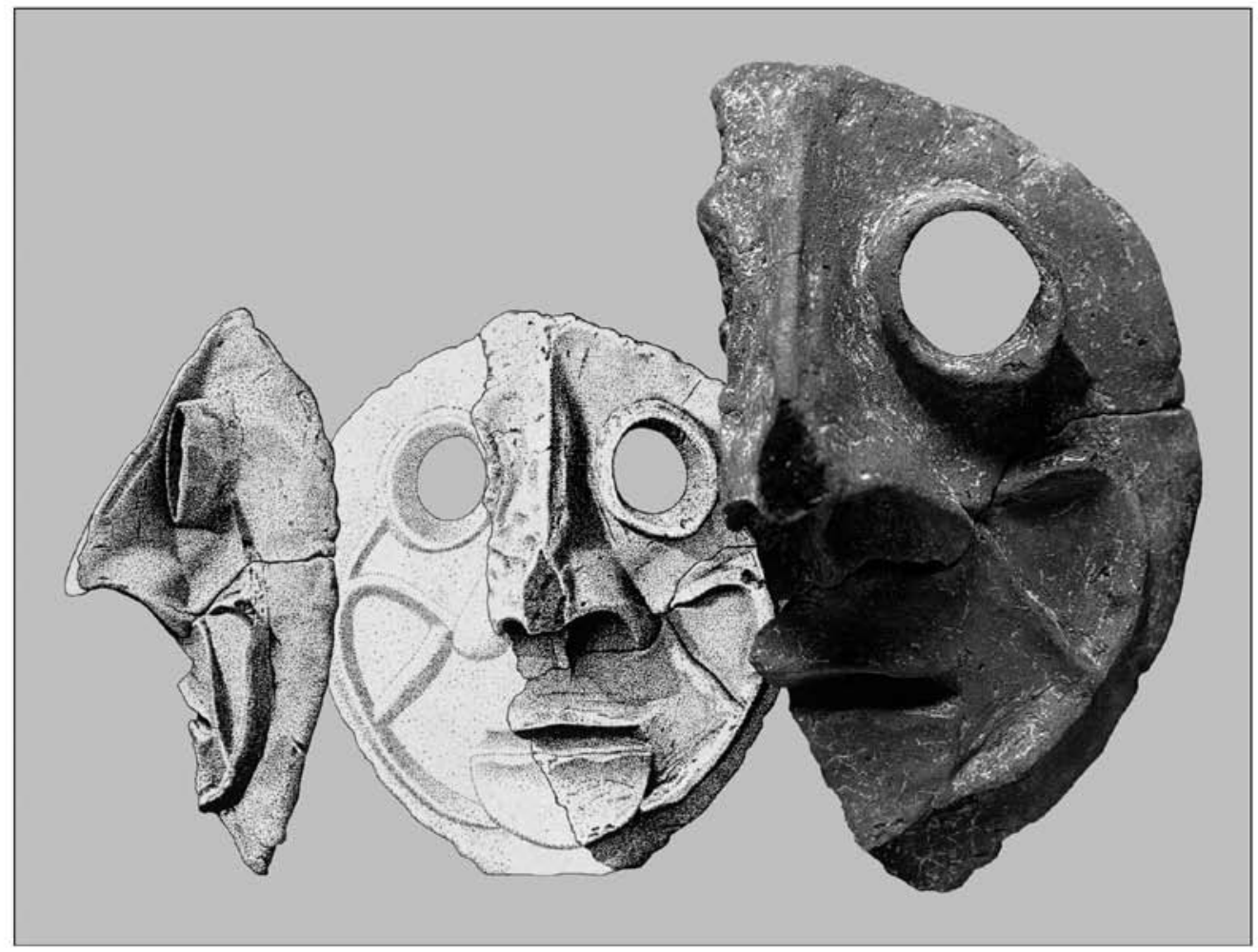

1.
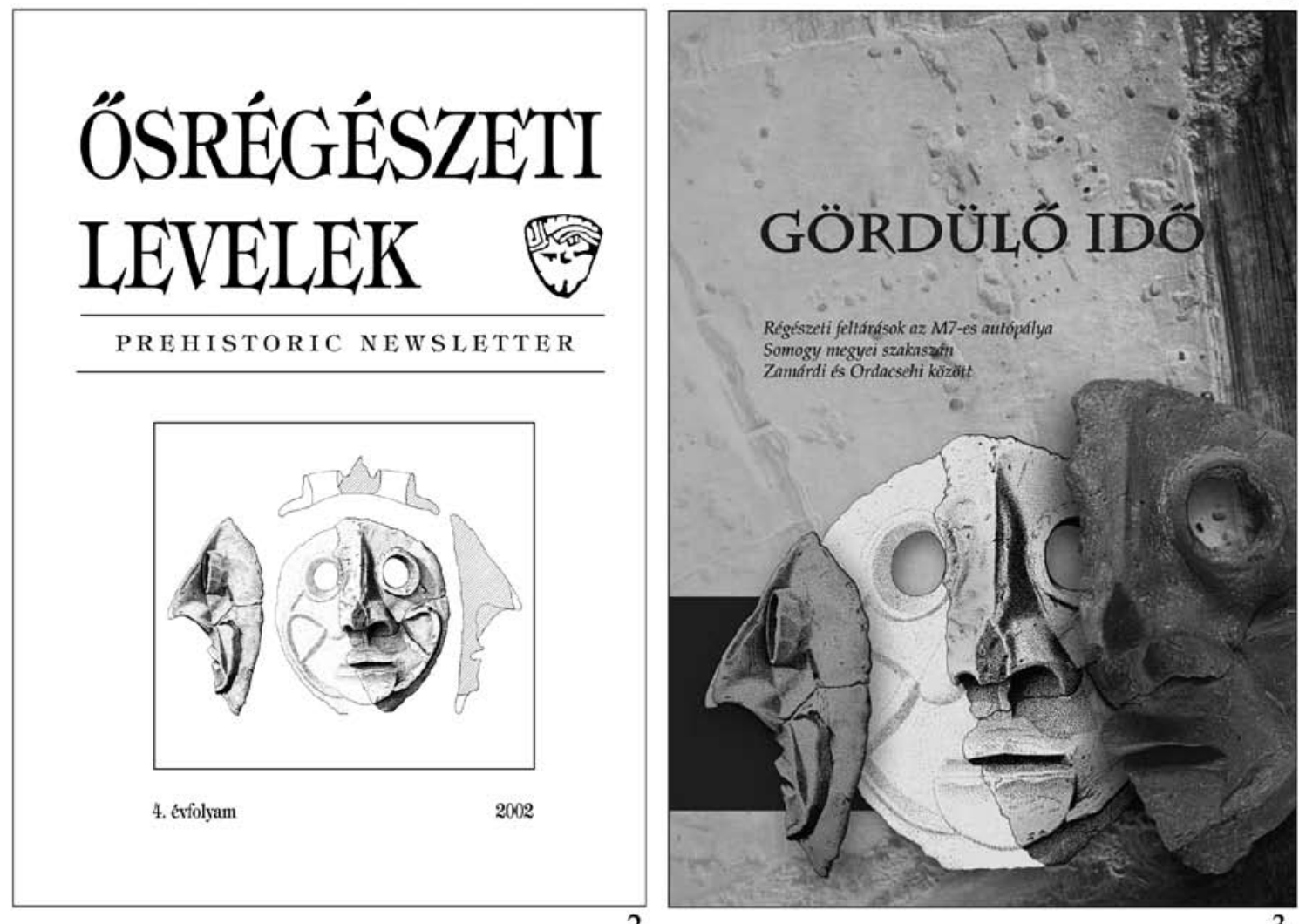

2 .

7. Tábla: 1. Az Élet és Tudomány 2002. évi karácsonyi különkiadvány elöfizetök számára. 2. Az Ősrégészeti Levelek 2002 borítója. 3. A Gördülő idő borítója. 

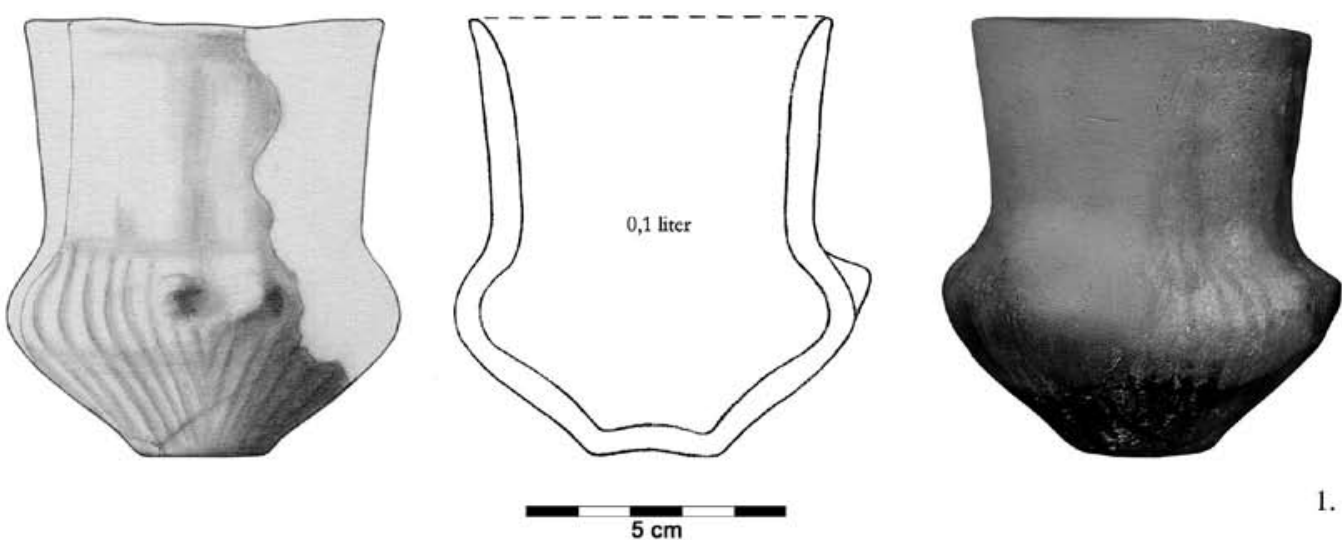

1.
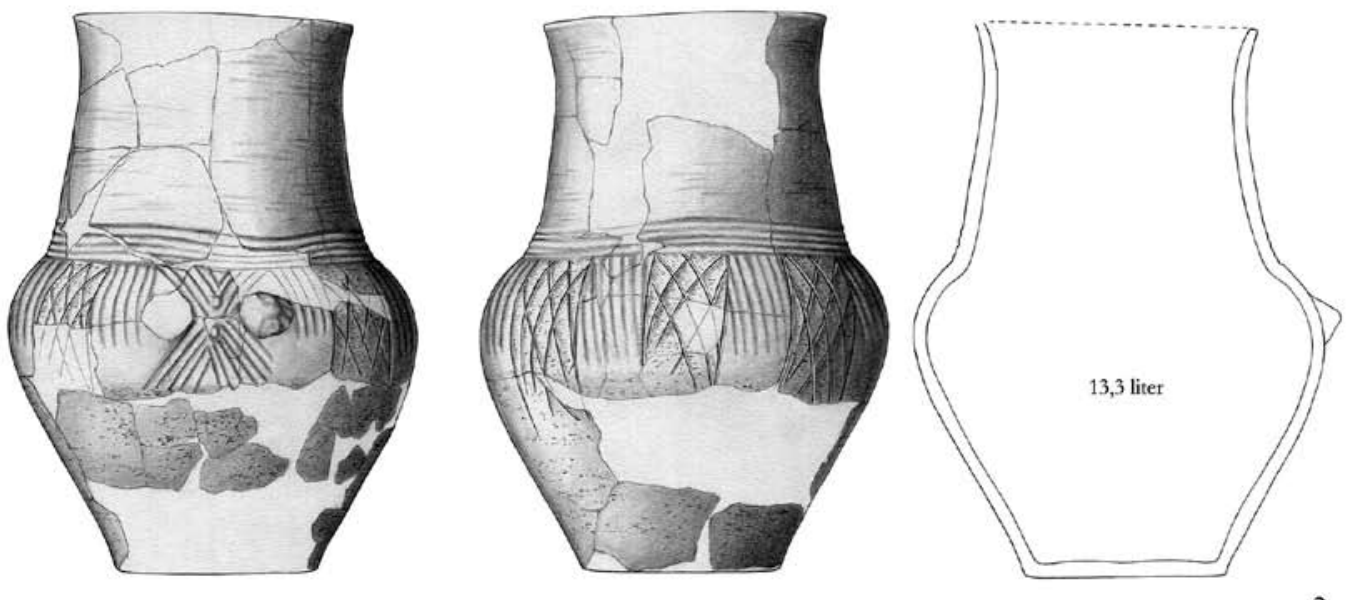

$-5 \mathrm{~cm}^{-}$

2.
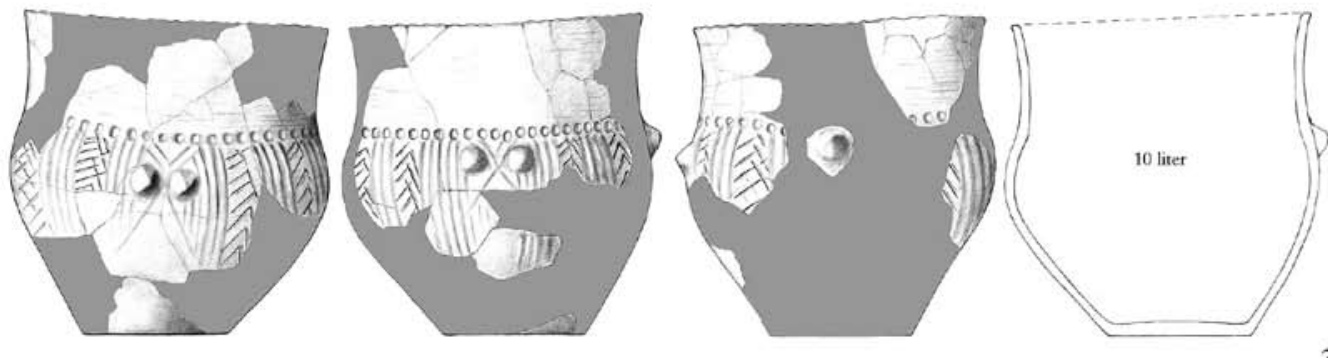

$-5 \overline{s m}-$

3.
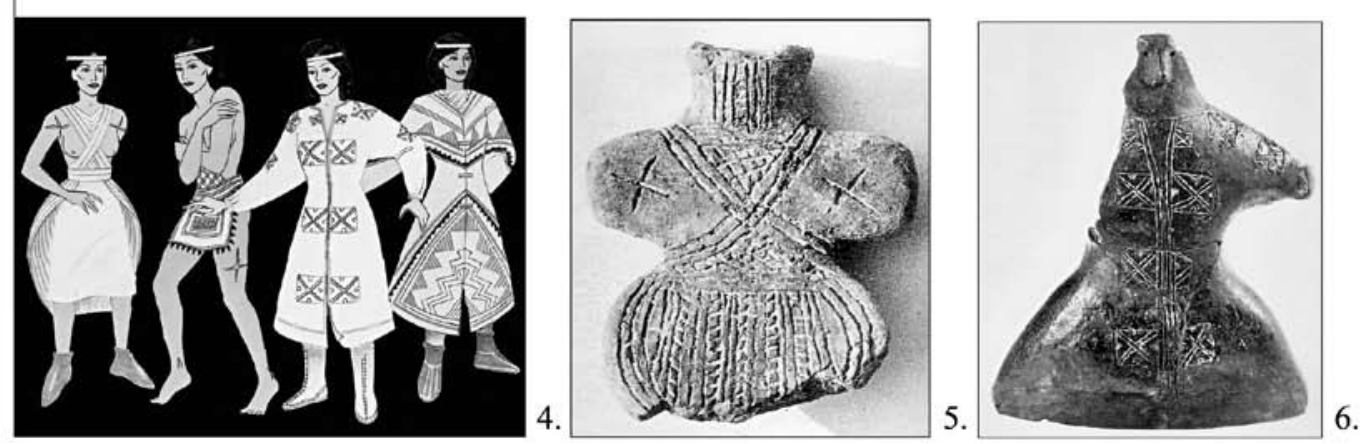

8. Tábla: Kebles edények Balatonőszöd-Temetői-dülő lelöhelyen. 1. 2302. gödör. 2. 247. kemence. 3. 2406. gödör. 4. Vučedol nöi ruharekonstrukció az idolok alapján, Durman 1988: 29. után. 5. Lapos Vucedol idol fej nélkül, Vinkovci-Hotel lelöhelyröl, Durman 1988: Cat. 33 után. 6. Térplasztikás, fejjel kialakított idol Ljubljanske barje lelöhelyröl Durman 1988: Cat. 36. után. 
a kerámia értékelése során arra a következtetésre juthatunk, hogy túl sok benne a későinek tartott elem, például mészbetétes díszítésű, Kostolác-jellegű postbadeni vonások, és sok, csak erre a területre jellemző edényforma és egyéb lelettípus jelenik meg (többek közt az arcos edények is). Ezt a benyomást azonban keltheti az a tény is, hogy a régióban levő, föleg magaslati településekként azonosított lelőhelyek anyaga egyértelmüen keveredik más, ugyanonnan származó kora és középső bronzkori leletekkel, amelyekben ezek a vonások úgyszintén jelen vannak, mivel a várakat későbbi korokban is lakják. Ezek a rossz megfigyelések, közöletlenség, és egyéb tényezők miatt már elkülöníthetetlenül bekeveredtek a badeni leletek közé.

A temetkezési lelőhelyeket vizsgálva feltűnő azok egységessége: mind rítusait (kőpakolás a sírokon, urnás-hamvasztásos mód, folyó melletti elhelyezkedés), mind lelettípusait (arcos edények) tekintve. Ezen négy lelőhely összetartozása rítusai alapján megkérdőjelezhetetlen. Kérdés viszont, hogyan illeszkedik a Baden kultúrába, amelynek nem ismerjük ilyen rítusú (urnás-hamvasztásos rítus) temetkezéseit csak igen kis számban (előfordul pl. néhány urnás hamvasztásos sír Budakalászon: 436 sírból 72 hamvasztott, ebből 6 urnás: BONDÁR 2009: 232; és Fonyód-Bézseny-pusztán: BANNER 1956: 37. lelőhely, 28-32), és amelyre az elkülönült temetők létesítése szintén nem jellemző túlsúlyban (mindössze Alsónémedi, Budakalász-Luppa-csárda, Vámosgyörk-Motorhajtóanyag-tároló, BalatonlelleFelső-Gamász, Balatonmagyaród-Hídvégpuszta-Déli rév tekinthető ebből a szempontból ilyen típusú temetkezési helynek Magyarországon).

A furcsa és eltérő rítus-csomag talán az Ózdpilinyi csoport a Baden kultúrában, vagy a Badenkomplexumban különleges kulturális (kevert vagy identitását őrző, de zárványként más kultúrák közt élő?), vagy kronológiai (nagyon korai vagy nagyon késői?), esetleg földrajzi (hegyi környezet=reliktum: elzártság-elzárkózás?) helyzetére utalhat (vagy mindháromra együtt). A kevert szituáción azt értem, hogy talán ha nagyon korai a csoport, a Boleráz kultúra egyik területi átfejlődése lehet Badenbe (erre utalhat a Bolerázra jellemző önálló temetkezési helyek létesítése, a hamvasztás szokása, az urnás, földhalom alatti, kőpakolásos temetkezési rítus). Lehet azonban a csoport nagyon késői is, ezen pedig azt értem, hogy a Baden kultúra 2800 BC utáni, tehát a késő rézkort túlélő csoportja, ami azért rendelkezik ilyen különleges vonásokkal a Baden kultúrán és komplexumon belül, mert a térségben megjelenő új, hagyományosan kora bronzkori kultúrák (pl. a Makó) vannak rá hatással. Nem zárnám ki az esetleges késői kultúrahatások közül a 2800 BC-t ugyancsak túlélő alföldi Gödörsíros kurgán csoportokat (vö. földhalom emelés), és az ekkor megjelenő Zsinegdíszes edényeket sem (vö. HoRvÁth 2011: 90; Dani-Horváth 2012: 89-107). Ami viszont teljességgel kizárható ma már, az ezen edények déli kapcsolatrendszerén keresztül Trójával és az ottani arcos edényekkel való bármiféle kapcsolata (vö. részletesen HORVÁTH 2012: 11-13).
Tény, hogy az arcos edények megjelenése a késő rézkori Badenben egyelöre rejtély, előzmény nélkülinek tűnik, és felbukkanásuk-kialakulásuk irányai egyelöre ismeretlenek, de ennek oka az, hogy talán nem minden kétséget kizáróan a késő rézkori Baden kultúrába tartoznak, hanem a kora bronzkorban élőbe. Ezt a feltételezést támasztja alá a Mediterráneum kora bronzkorából ismert több arcos edény lelet, amely az északkelet-magyarországi badeni leletek elég jó formai párhuzamaként értékelhető, mint az régóta köztudott (MıLoJčıć 1979: Taf. 11: 2.1b3; Taf. 15: 2. 1a, 1b1, 1b2, Ila, Ilb, Ilc; Taf. 30: 1. 7A/a, 2. 7Allb, Trója-Ilion, Frühtrojanisch II b/c, c/d; KALIcz 1963). Az arcos edények sematikus arc-kialakítása mutathat a néhány, fejjel ábrázolt badeni atipikus idol szintén sematikus arcára, és a diadém feltünése ezen idolokon és az urnákon szintén kanonikus közös elem lehet. További értelmezési irányt jelenthet a „badeni” arcos edények egyetlen jó párhuzama Debrecen-Köntöskertröl, a kora bronzkori Makó kultúra lelöhelyéről (6. Tábla: 4), amely a hiteles feltárási körülményeknek köszönhetően egy Makó urnás-hamvasztásos sír pohárka-melléklete volt, tehát az edények feltünő formai hasonlóságán kívül még a temetkezési rítus is megegyezett (NÉMETI-DANI 2001: Fig. 9: 1)! Úgy gondolom, a problémakör teljes és megnyugtató lezárása csakis új természettudományos vizsgálatok bevonásával oldható meg, amelyek elvégzése a magyar őskori régészet régi adóssága (a hamvak ma már megoldható radiokarbon, ill. az edények radiokarbon vagy TL-OSL mérésével).

A vizsgálat szempontjából említett kebles (gynekomorf), ill. kezes vagy lábacskákon álló edényeket minden részletre kiterjedően bemutattam több tanulmányomban, ezért nem ismétlem el az ott közölteket (HORVÁTH 2010b: 3-15. a rituális; HoRVÁTH 2012: 21-25 a tipológiai-kronológiai aspektusából mutatja be ezeket az edényformákat). Néhány, a tanulmány összegző-értékelő volta miatt fontos részletre hívnám fel itt a figyelmet mindössze. Mindhárom edénytípusnak ismerjük a korábbi korszakokból és kultúrákból való formai-tipológiai párhuzamait, és a kebles edények kivételével a másik két edényforma más kultúrákban való előfordulása is biztosnak mondható (vö. Kostolác, Vučedol, Harangedényes talpas ill. kezes edények, 9. Tábla).

Ez a rítus, az ábrázolástípus és a jelentéstartalom nemcsak a Baden-komplexumra jellemző, hosszú időszakon át folytonos, formailag kissé változó meglétre utal. A gynekomorf edények kialakulásának felbukkanása a középső rézkor vége időszakban a nyugatközép-európai tóparti településeken (ScHLICHTHERLE 2010) egyértelmű kapcsolatrendszert jelent a késő rézkori Boleráz megjelenésével-terjedésével, hasonlóan a rézmegmunkálás, csúszka, pecsétlők, sztélék, magaslati szentélyek használatával. Ugyancsak megjelenik rituális házplasztikákon, egyértelmű szimbólumrendszerben a terhesség, szoptatás anatómiaitársadalmi folyamatával (fehér festés jelzi az anyatejet a mellplasztikákon, 5. Tábla: 5), és a női termékenység-kultuszokkal. A korai kebles edényeken ritkán 
feltűnő mellszalag ábrázolása a badeni tipikus idolok hasonló ábrázolásával mutat közösséget és átöröklödést korokon, kultúrákon, és tárgytípusokon keresztül. Különös egyezést és túlélést mutat a kebles edények mindenkori Furchenstich-jellegű díszítése, függetlenül attól, hogy középső, késő rézkori, vagy kora bronzkori kultúrák leleteként lát-e napvilágot (9. Tábla).

A balatonőszödi feltárás eredményei annyiban vezettek bennünket tovább, hogy a 1315. gödör esetében egy ritka festett-karcolt kombinációjú, a 2302. gödörben előkerült egyetlen bolerázi edény esetében pedig nem amfórán, hanem korsón kialakított edényformán jelent meg a kebel-ábrázolás, egyértelmű mellszalag-feltüntetés nélkül (8. Tábla: 1). Az 589. gödör és a 247. kemence kebles edényei (8. Tábla: 2 ) esetében egyértelmű kapcsolatot tártunk fel a tüzzel való érintkezésben (a kebles edényekben levő ital- vagy étel-készítéséhez, vagy magához a rítushoz - égőáldozat? - kapcsolódóan?). A 2406. gödör leletén körben 3 pár kebel helyezkedett el (8. Tábla: 3), talán egyfajta természetfölötti szaporodásra/termékenységre utalva (hármas ikres terhesség?). A kezes edényeken megfigyelhető adoráns kéztartás szintén korábbi és későbbiekben is előforduló állandó elem, amely az edény- és idol-ábrázolásokban is hasonlóan kanonikus (kivéve éppen a badeni tipikus idolokat!). Mindhárom edénytípus inkább a Baden kultúrában fordult elő, előzményük azonban néhány egyértelműen korábbi, tiszta bolerázi, ill. bolerázi-badeni átmeneti fázisokban, egyidejüleg vagy utólagosan pedig a Kostolácban és Vučedolban a Baden-komplexumon belüli kultúrák közti szimbolika folytonosságot és azonosságát bizonyítja. A včelincei sírban az arcos, arcos-kebles edények, és az idol együttes előkerülése pedig arra világít rá, hogy különböző tárgytípusokban ugyanaz a szimbólumrendszer és mitológiai elképzelés manifesztálódik, amelyek a halotti rítusokban ugyanazzal vagy egymást átfedő jelentéstartalommal felruházva voltak együttes, vagy egymást kiegészítő, felváltó használatban.

Összefoglalásképp az emberi vonásokkal felruházott edényekről elmondható, hogy a fazekasság kezdete óta szinte minden őskori kultúra hagyatékában megtalálhatók, ábrázolásaikban felfedezhetők hasonló vagy azonos vonások az adott kultúrák más, rítusokhoz kapcsolódó tárgytípusai felé (legfőképpen az idolokkal), ezért jelentésük és vallási funkcióik közt is lehetnek hasonló vagy azonos, esetleg átfedő vonások. Több szerző és tanulmány véleménye szerint ezek az edénytípusok az Ősök ábrázolásainak egyfajta képviselői, és ezzel együtt az adott társadalom egyik fontos kifejezési nyelve (BARLEY 1984, 1994; GosselEIN 1999). $\mathrm{Az}$ a többlet, amivel egy edény rendelkezik a benne tárolt vagy magába fogadó anyagok szubsztanciájával kiegészülve még egy további pluszt jelenthet az azonos rítusokban is az idol-használat mellett (vö. ételvagy italáldozatok, értékes, a rituálé során használt anyagok tárolása, hamvak vagy maradványok befogadása, mint új funkció az idolokkal szemben, amelyek ezekre nem alkalmasak).

\section{Kőművesség: Sztélék}

Az ún. kőből faragott menhírek vagy sztélék (StatueMenhir; Statues-Stelae) Európa nagy részén terjedtek el a késő rézkor és a kora bronzkor folyamán, 3500-2000 BC között (DimitRIADIs 2008; Robb 2009; SCHLICHTHERLE 2010) (3. Tábla: 3). Elterjedésük az északi félgömb őskorának kultúrái közt szinte teljes térbeli, és pontos időbeli egyezést mutat a páros szarvasmarha-temetkezések elterjedésével (vö. HoRVÁTH 2009: 116, 118-120) (3. Tábla: 2).

E különös egybeesés mögött talán ugyanarra az éghajlati jelenségre (vagy több hasonlóra) adott társadalmi-rituális válaszreakció látható. A környezetkutatók az éghajlat fluktuálódása mellett egyértelmü, hosszabb-rövidebb ideig tartó romló periódusokat is kimutattak, amelyek egyéb jelekből kiolvashatóan légköri jelenségekkel voltak összefüggésben (pl. tartós felhővel borítottság, savas eső vagy egyéb csapadék, napkitörés, sarki fény, stb.: MAGNY 2004; MAGNY-HAAS 2004; MAGNY et al. 2006). Antik vagy magas civilizációkban a szarvasmarha-áldozatok rendszerint napkultuszhoz kapcsolódnak (pl. Egyiptomban és a KözelKeleten, vö. Pollex 1999). Amennyiben az európai őskori társadalmak szarvasmarha-áldozattal kapcsolatos képzetei alacsonyabb társadalmi és szakrális szinten szintén ebbe az irányba mutatnának, úgy az éghajlatromlás, a szarvasmarha az időszak során kezdődő másodlagos új felhasználása, ennek reprezentálódása a profán és a szakrális világban egyetlen rendszer elemeit alkotnák. Az éghajlat-romlás mögött megbúvó jelenségek felderítése nehéz feladat az éghajlat egyébként is állandóan változó volta, a szükségszerüen bekövetkező nagyobb, globális klímaváltozások, na és az őskori napi adatok hiánya miatt. Néhány látványos légköri jelenséggel járó, akár az egész északi félgömbre vagy annak bizonyos részeire korlátozódó, a korszakhoz kapcsolódó vulkánkitörés azonban sok mindent megmagyarázna ezen a téren. Sajnos a vulkánkitörések időbeli „belövése” és lokalizációja szintén nem egyszerü feladat. A vulkáni hamunak tufaként vagy tefraként való azonosítása régészeti lelőhelyeken eddig csak a paleolitikumban fordult elő. A képződött tufa és a vulkán egymás közötti viszonyának felderítése még nehezebb: vagyis megtalálni a néha több száz vagy ezer kilóméterrel odébb sodródó kitörési felhő eredendő helyét, magát a vulkánkitörés helyét. Mivel az időszak szarvasmarha-áldozatai inkább északi irányban rendeződnek (HORVÁTH 2009: Fig. 15), és nem dél felé, valószínübb azt feltételezni, hogy 3500-2000 BC közt az Altmärkische Tiefstichkeramik, a Tölcséres szájú edények, annak Salzmünde csoportja, a Baden, Złota, Gömbamfórás, és a Zsinegdíszes Schönfeld csoportjának emberei egy északi tektonikai övezetben (Izland, stb., vö. HARANGI 2013) kitört vulkán által okozott környezeti katasztrófa jórészt középeurópai áldozataiként azért mutattak be egymáshoz hasonló szarvasmarha-áldozatokat akár egymástól függetlenül, mert ugyanazt látták az égen (pl. napot tartósan nem), ugyanazoktól a hatásoktól szenvedtek 

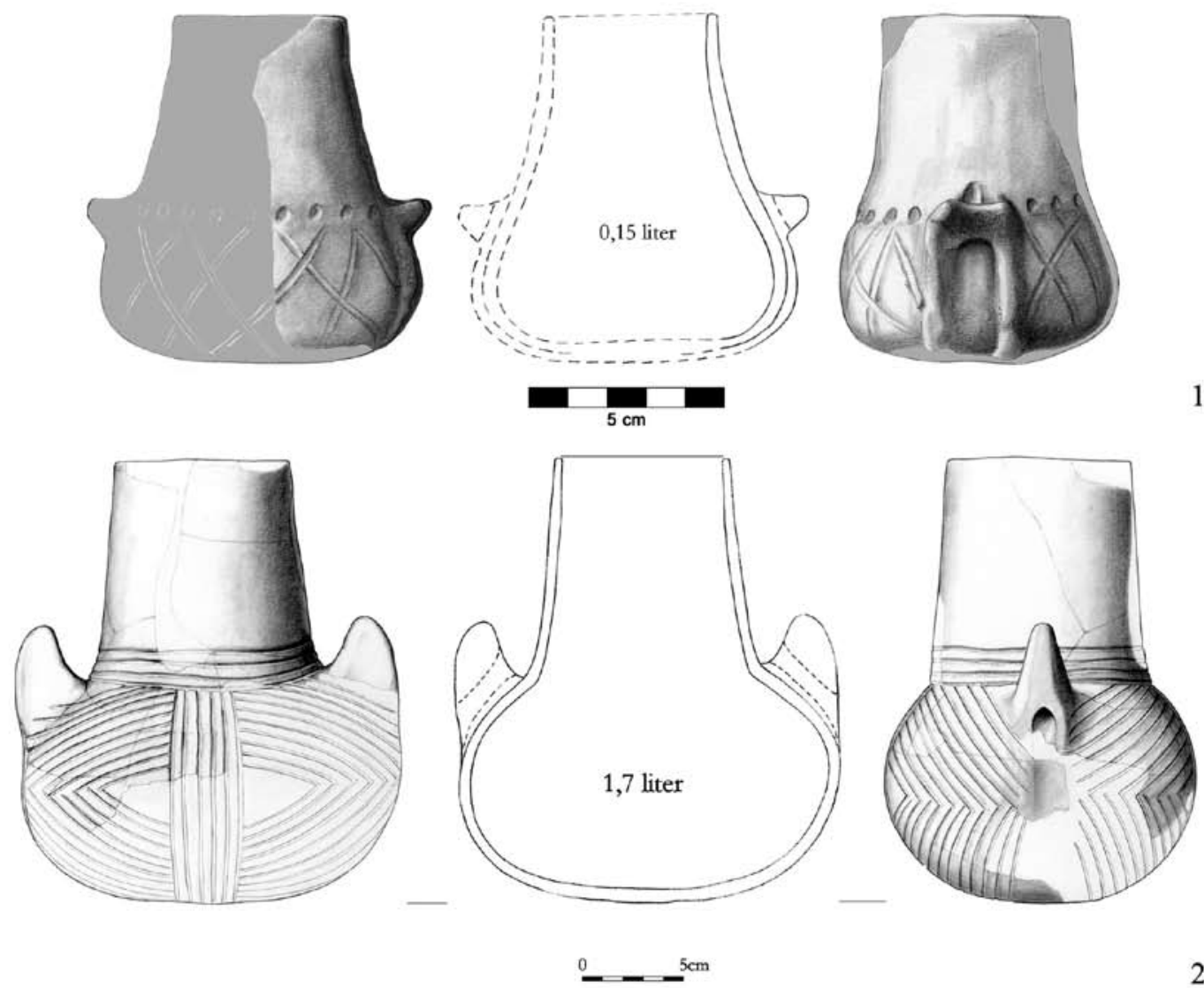

2.
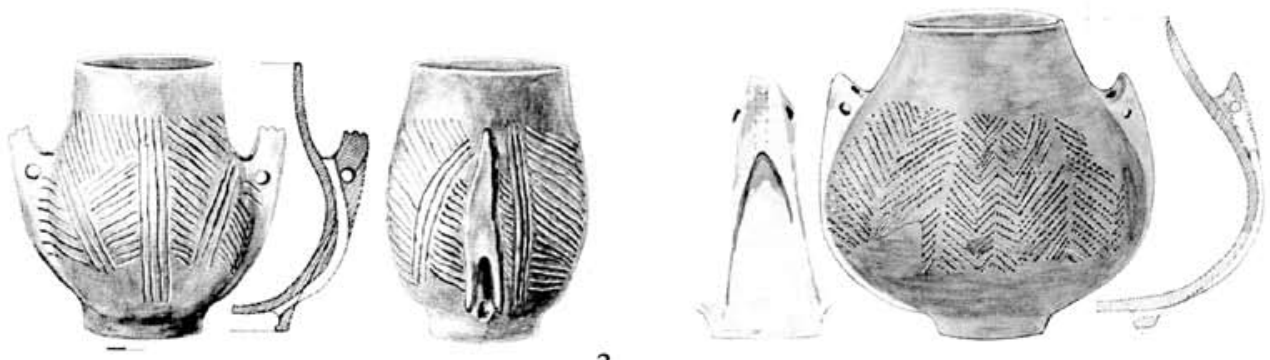

3.

4.

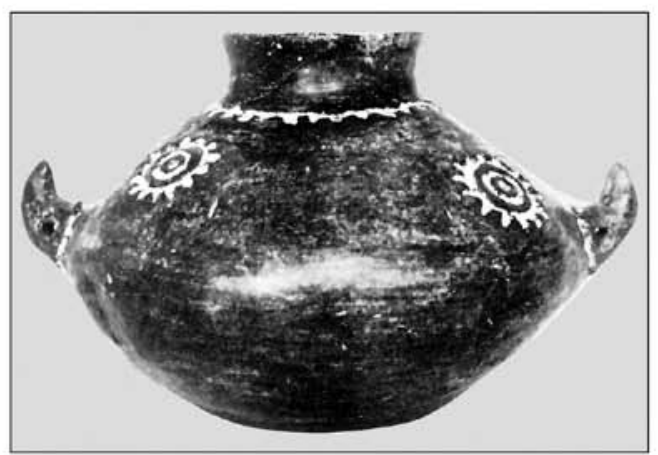

5.

9. Tábla: Kezes edények a Baden-komplexumban. 1. Balatonőszöd-Temetői-dülő, 1794. gödör. Piros festettkarcolt. 2. Balatonöszöd-Temetöi-dülö, 743. gödör. 3. Gomolava, 4. gödör, Baden kultúra, Petrović-Jovanović 2002: 24 után. 4. Gomolava, Kostolác kultúra. Petrović-Jovanović 2002: 215: 11. után. 5. Kezes edény a Vučedol kultúrából Durman 2000: Fig. 10. után. 
(pl. savas eső, állandó felhőtakaró), és kultúrájuk, gazdasági életük hasonló elemei alapján egyedül a szarvasmarha feláldozásától remélték az ősök és a természetfeletti hatalmak segítségét.

A kőhasználatban két, tipológiailag és földrajzilag megkülönböztethető kör különíthető el: az atlanti, megalitikus előzményekkel is rendelkező tradíció (SCARRE 2010; LICHTER 2010) és a keleti, steppei tradíció, amelyek Közép-Európa, elsősorban a Kárpát-medence és a Mediterránium területén, mint két halmaz találkoznak és metszik egymást (3. Tábla: 3). A két kör talán önálló, egymástól független kialakulással rendelkezik, bár ez nem bizonyítható teljességgel. Datálási és feltárási nehézségek miatt, hasonlóan a kocsi és a kerék kialakulásához és elterjedéséhez (HoRVÁTH 2014c), ez a kérdéskör is további kutatásra és pontosításra szorul. Ebből a szempontból nézve Magyarország a két zóna találkozási-ütközési metszésében fekszik, és ennek megfelelöen leletei is mindkét kört illetve azok egyfajta fúzióját tükrözik (HORVÁTH 2009:116-117; HoRVÁTH 2011b: 45-47).

A sztélé- vagy menhír-állítás szokása összekapcsolódik az ebben az időben élő kultúrák több aspektusával, mivel a kultúra integrált, és minden eleme egymással összefügg. Ez tükröződik a már említett környezet-ember találkozással kapcsolatos, a korszakban elkezdődő ábrázolásokban is.

Először is a kultúrák éghajlati ingadozások miatt mobilisabbá forduló életmódjával, a földművelésről az állattenyésztés súlypontjára való változásával. Ez miatt a korábban kevésbé kihasznált magasan fekvő, de legeltetésre bizonyos időszakokban kiválóan alkalmas hegyi területek intenzívebb kihasználása mutatkozik. Az itt található barlangokat átmenetileg állati- és emberi célú szálláshelyként használják, ez az elsődleges oka a korszakban a barlangi leletek felbukkanásának, bár másodlagosan használhatták rituális célra, búvó- vagy rejtekhelyként is (ARNOLD-GREENFIELD 2006). Ezzel együtt az ide feljutó és időszakosan itt élő emberek további, itt elérhető és felhasználásra érdemes nyersanyagokat kezdenek kiaknázni (fémek, fa, kőnyersanyagok: kovák és nefrit, só, cseppkövek, Strahm 2010; Pétrequin et al. 2010; Ramminger 2010; Kieselbach 2010; KeRIg 2010; Gronenborn 2010). A sík és hegyi területek közti folyamatos összeköttetés igénye, a transzhumáló életmód, és a fuvarozás miatt kialakulnak a szállítóeszközök új fajtái: a szán után a csúszka, majd a kétkerekű kordé (RoLA 2009). A hegyi és az alföldi élet azonban nemcsak a földi javak terén áll összeköttetésben, hanem a szellemi élet transzformált síkján is: az egekbe emelkedett, tiszta térben megjelennek a magaslati szentélyek (peaksanctuary), temetkezési helyek és egyéb ceremoniális helyszínek. Ezek környékén mind gyakrabban bukkannak fel a sztélék, a nyers sziklákon vagy a temetkezés során használt megmunkált építőköveken különböző, a hétköznapi és a vallási életet, igába fogott vagy szántó szarvasmarhákat, kereket, járműveket és egyéb szimbólumokat, presztízstárgyakat (balta, tőr, szemüvegspirál-csüngő, stb.) ábrázoló petroglifek, vésetek (NADLER 2010), és a szent helyek környezetében végzett ún. rituális szántás nyomai. Néhány hitelesen feltárt lelőhelyen megfigyelhető jelenség alapján úgy gondolják, hogy a legtöbb sztélét az Ösök tiszteletének állították, és korábban vagy mellettük fából készült sztéléket is használtak. Néhányról felmerült, hogy határjelző szerepet láthattak el.

Magyarország területén három e tipológiai csoportok valamelyikébe sorolható lelet került eddig elö. A Mezőcsát-hörcsögösi lelet Gödörsíros kurgán alatt és badeni sírok között, a Budapest-káposztásmegyeri egy badeni településen, emberi és állati temetkezések környezetében, a kevermesi darab pedig szántás közben, szórványként látott napvilágot. Mindhárom lelet eredeti helyéből kimozdítva, másodlagos előkerülési helyen.

A mezőcsáti sztélé formai párhuzamai a steppei Gödörsíros kurgánkörből ismertek (HORVÁTH 2011: 88, 90. lábjegyzet; DANI-HORVÁTH 2012: 93, 128. lábjegyzet). Regionális, kb. a lelőhelytől 20 km-re található kőnyersanyagból készült anikonikus sztélé. Kevermes határában egy vésett díszü, az előzetes információk szerint az atlanti megalitikus temetkezési helyek véseteire hasonlító építő-, oltár- vagy zárókő (petroglif) került elő, amelynek nyersanyaga viszont keleti, távoli, a lelőhelytől kb. 100 km-re fekvő zöldpala, feltehetően a Temes, Maros folyók, vagy a déli-Kárpátok területéröl (BóKA et al. 2013). Ebben az esetben az atlanti és a steppei tradíciók találkozásáról, ötvöződéséről tanúskodik. A lelöhely talán valamelyik közeli kurgánhoz köthető, bár ez utólag már nem bizonyítható. A káposztásmegyeri lelet anikonikus monolit-menhír, helyi nyersanyagból. A magyarországi két, badeni kultúrához köthető lelet díszítetlen. Más, elsősorban alpi sztéléken azonban kebel-ábrázolás, mellszalag, nyaklánc (hasonló a Velvary-ban feltárt kőládás (cist grave) csontvázas és urnás temetkezéseket is tartalmazó sír réz pektoráléjához), és egyéb státus-szimbólumok is láthatók, amelyek az idol-ábrázolásokon is feltűnnek, ill. a fej-kialakítás (vö. SchlıchtHERLE 2010: 274: 3-5) néha szintén a sematikus fejjel kialakított idolokéra és az Ózd-pilinyi csoport antropomorf urnáinak fejére emlékeztet. Csehországban, Kladno körzetében egy kő idolt tártak fel badeni környezetben (NEUSTUPNÝZÁротоскÝ 2013: 96, 99, Fig. 28), amelynek alakja leginkább egy sztéléhez hasonlít (6. Tábla: 7).

\section{Kulturális antropológiai és régészeti értékelés}

Egy őskori kultúra vagy kultúrkör (ez esetben a Baden-komplexum) teljes megítélése során, különösen a nem tárgyi emlékanyag értékelésekor szükségünk van a régészet mellett más tudományterületek bevonására is, hogy jobban megértsük az ehhez társuló szellemi folyamatokat. A legegyszerübb módszer a hasonló („őskori”) körülmények közt élő hagyományos paraszti/primitív népek kulturális antropológiai és néprajzi esettanulmányainak bevonása, mivel ezek körülményei, jelenségei és tárgyai vizsgálata mellett e két további tudományterületnek arra is lehetősége van, hogy az élő adatközlőktől további kigészítő-magyarázó 
információkat szerezzen. A Baden-komplexum részeit képező kultúrákhoz afrikai, elsősorban állattartó (föleg szarvasmarha-tenyésztő, kiskérődzőkkel kiegészített), ez mellett köles-termelő falusi szinten élő társadalmakat választottam. A közöttük vonható párhuzamok több más munkámban már kis részletekben említésre kerültek. Most egyetlen népre koncentrálva röviden bemutatom a helyszíni terepmunkák alapján a Doajo (Dowajo) népet abban a vonatkozásban, ahogy ezt a tanulmányban vizsgált témakörök és a köztük levő kapcsolódási pontok kijelölik.

Elöre szeretném hangsúlyozni, hogy az itt következők nem jelentik azt, hogy ezt a képet egy az egyben megfeleltetem az őskorival. Egyetlen olyan kultúrát sem lehet találni a Földön, amelynek rendszerét tökéletesen rá lehetne húzni egy másik kultúrára. A modell sok szempontból egyezik: a Doajóknál van Ős- és Halott-kultusz, sőt, koponya-kultusz és múmiák, antropomorf vonásokkal ellátott edények amelyeket festenek és kerámiazúzalékkal soványítanak az Ős kerámiában való újjászületése érdekében; van körülmetélés és beavatási szertartások, termékenységi szertartások, szarvasmarha- és kiskérődző-áldozat, mágia. Jórészt állattartók, de részben köles-termelők (Balatonőszödön az egyetlen megtalálható növényfaj volt); bár falvaik vannak, de idény szerint életük nagy részét pásztorkodással, őrzéssel és a köles-földeken, tehát a falvakon kívül töltik. Megvannak az egalitárius társadalomra jellemző vonások a falusi vezetők nem öröklődő, és szinte semmilyen kiváltsággal nem járó státuszával; de a Fulanik miatt van egy magasabb szinten rétegződő társadalmi viszony is, amelyben egyértelmüen alárendelt szerepet játszanak a Doajók. Saját társadalmukon belül bizonyos specializációk szegregáltak: a kovács, fazekas, sírásó, gyógyító tisztátalan és alávetett. Sok elem azonban, őszintén be kell vallani: hiányzik. Így például, bár vannak agyag emberi figuráik, de nem idol-szerepkörben; hiányzik a Guineai-öböl mentén élő népekre jellemző gazdag és árnyalt maszk-használat, hacsak a maszkírozást nem erőltetjük ide; a leszármazási és letelepedési rendszer és a Baden-komplexumra jellemző rendszerek ez utóbbi ismeretlensége miatt nem vizsgálhatók, ezért össze sem hasonlíthatók egymással; ezen kívül a trópusi növényzet, állatvilág és éghajlat valamint a Kárpát-medence jellemzői eltérnek, és így tovább. A holt régészeti anyagnál azonban az eltérések ellenére ezek az adatok többet árulnak el, sok esetben megvilágítanak homályos vagy láthatatlan régészeti részleteket. Ezekre az adott helyeken felhívom a figyelmet.

Doajoföld Közép-Afrika keleti részén, Észak-Kamerunban található. A terület földrajzi és geopolitikai helyzetéből adódóan az eredendően agresszív nomád, föleg szarvasmarha-tartó, iszlám hitre áttért Fulani népcsoport uralkodik számban és kultúrfölényben (túlnyomó többségben ma már városi életmódot folytatnak, belölük kerülnek ki az ország hivatalnokai és egyéb vezetői, vidéken pedig kereskednek, szállítanak, stb.). A Doajók számban és kultúrfölényt tekintve alattvalói szerepben egy hegyi és egy síkvidéki alcsoportra válva egészítik ki az ország társadalmát. Az ország területén azért persze további népcsoportok is élnek, amelyek eltérő nyelvi, gazdasági életmódot folytatnak: még a ma legősibbnek tartott pigmeus csoportok is megtalálhatók. A hegyi pogányokként nyilvántartott Doajókról Nigel Barley terepmunkái előtt kevés, jórészt hiányos és téves adatok álltak rendelkezésre (BARLEY 1983, 1984, 1994). A fenti szituációból adódóan a Fulanik mindenféle szempontból lenézik és mélységesen megvetik a Doajókat, a Doajók gyűlölik a Fulanikat, a hegyi, „vad” és az alföldi, „szelíd” Doajók pedig kölcsönösen utálják a másikat és a másiknál különbnek nézik magukat. A status qou-t tovább árnyalják a kulturális és nyelvi különbségek, a két nép közti alapvetően különböző habitus (a Fulanik a nomádságból adódóan agresszív és területszerző-hódító politikát folytatnak, amelyet vallási okokkal is megtámogatnak, míg a Doajok nyugodt, békés agráréletet), és az Afrikára jellemző alapvető rasszizmus. Ez a kép akár egy az általunk tárgyalt 4000-2000 BC közötti őskori helyzetet is híven illusztrálhat, amennyiben a Fulani-hegyi Doajo-síksági Doajo viszonyba behelyettesítünk pl. egy Gödörsíros kurgán hegemónia alatt élő BolerázBaden vagy Baden-Kostolác, esetleg kora bronzkorban tovább élő Baden-Makó interkulturális találkozót a Kárpát-medence területének bármely erre alkalmas hármasságot mutató lelőhelyén.

A Doajo falvak kör alakú sárkunyhókból állnak, kúpos fütetővel. Minden falu előtt egy kör található, ahol a nyilvános tanácskozások, bíráskodás, rítusok zajlanak, és ahol a szentélyek is találhatók. Emögött egy másik kör fekszik, ahol a közös tulajdonban levő csordát tartják, majd a fönök és a közrendű lakosok kunyhói. A fönökök egyszerüen gazdag férfiak, akiknek marhacsordájuk van, ezért könnyebben megszervezhetik a vallási ünnepeket (amihez többek közt szarvasmarha szükséges), ezzel lekötelezhetnek szegényebbeket, ezért kevesebb fizikai munkát végeznek. Sok Doajo főnök Fulaninak öltözik és fulaniul beszél, hogy presztízsét emelje sajátjai közt (akkulturáció, mesterséges, rájátszott státus-emelés, adopció). Velük szembeni társadalmi elvárás, hogy többet fizessenek ugyanazért a munkáért, és hogy ajándékozzanak a közrendüeknek.

A státusz az ültetés rendjében is szigorúan tükröződik. Általában mindenki két vagy három, a közelben lakó népek által használt nyelven is beszél (ma pedig még angolul vagy/és franciául is), mivel gyermekkortól együtt élve automatikusan elsajátítják, ezért nincsenek alapvető nyelvi megértési problémák a gyökeresen nyelv-idegen szomszéd faluközösségek közt sem. A fulani csere- vagy közvetítő nyelv, mivel a Fulanik kereskedők, utazók és hivatalnokok egy személyben Doajoföldön. Saját nyelvüket a Doajók annyira egyszerünek tartják, hogy nem tudják elképzelni, hogy nem lehet megtanulni. Európai számára azonban nagyon nehéz: politon, vagyis a hanglejtés befolyásolja a jelentést. Négy hangszín van, és hozzá még nyelvjárások. A Doajók egymással (egy falun belül és a falvak egymással) toleránsak, nyugodtak, tréfálkozók, szó sincs 
a Pápua-Új-Guineában szokásos 'már a szomszéd falu is a halálos ellenségem'-hangulatról. A társalgási szint a földekről hazavezető keresztutak találkozásában üdvözléskor kedélyesen udvarias: a „Neked tiszta az ég?” kb. a magyar „Hogy s mint, és mi újság?”, az angol „How do you Do?” vagy a francia "Common ça va?" kifejezéssel egyenértékü. A párbeszéd fenntartására az európai szokással ellentétben - amikor szembenézve, udvariasan végig kell hallgatnunk a másikat - ők gyakori közbevetéseket tesznek (igen-igen; nahát! ez így van!, stb.), földre sütik a szemüket, és elöre hátra billegnek a sarkukon (ezt a „rossz” szokást néhány izguló tanuló alkalmazza felelés közben Európában), hogy biztosítsák a másik felet folyamatos figyelmükről. A szótlanná váltat így biztatják: „Mondj valamit!” Tiszteletüket azzal mutatják, hogy „Öreg”-nek szólítanak valakit, korától függetlenül. Más népekkel a róluk terjedő „vad”-hírük miatt szégyellősek, félszegek - amikor kicsúfolják és kinevetik őket, azonnal elhallgatnak.

Amíg a köles a földben van, többen sátrakban kinn alszanak a földeken, nehogy a marhák feldúlják a termést (vö. a Baden letelepedésre adott modellemet, HoRvÁTH 2014). Az őrzést kisfiúk végzik általában, de a marhák így is sok kárt tesznek, mivel a gyerekek mostanában iskolába kötelesek járni. Minden asszony tudja, hogy ha a földjét feldúlják, az a házasságtörés dönthetetlen bizonyítéka, és a férje alaposan ellátja majd a baját: ezért a nők különösen éberen őrködnek. A földrajzi adottságok miatt a Doajók életének a köles a meghatározója: szinte nem is esznek mást, mert minden mástól félnek, hogy megbetegíti őket; erről beszélnek állandóan; ez a gazdagság mértékegysége; ezzel fizetnek; ebből főznek sört (nagyon rossz, csekély alkoholtartalmú és gyenge sört, amitől viszont iszonyú gyorsan lerészegednek, mert nem bírják); és ezt találják a világon a leghasznosabb, legfinomabb, legpompásabb dolognak.

A föld szabad tulajdon, bárki annyit vehet el és ahol-ahogy akarja, ez azonban a külső tényezők miatt nem vezet mezőgazdasági felesleghez: a talaj müvelése nehéz, az éghajlat kiszámíthatatlan, stb (vö. a vizsgált időszak éghajlatát). A kapálás unalmán közös sör-piknikekkel enyhítenek, sorra látogatva egymás földjét. A Doajók eladhatnák a felesleget a piacon (ha lenne feleslegük), de a piacot a Fulanik ellenörzik, a szállítást ők irányítják, és a haszonra ráteszik a kezüket. A Doajók csak annyit termelnek, amennyire szükségük van, ezért nem várt rossz termés akár éhínséghez is vezethet. A felesleg, csere, piac, javak szerzése nem érdekli őket: inkább cserélnek és adósságot halmoznak fel, amelyet egy marha levágásával meg lehet váltani. A falvak közt van egy, ahol a Föld Őrzője él (minden falunak lehet külön szerepe a Badenben is, vö. Balatonőszöd mint szertartási falu-lehetőséget: HoRVÁtH 2014). Ő az az ember, aki biztosítja minden növény termékenységét, ezért az ottani rítusok kicsit különböznek más falvakétól.

$A z$ aratáshoz meg kell építeni a szérüskertet: ennek alapja egy földbe vájt, sárral, marhaürülékkel és ragacsos növényekkel kikent sekély mélyedés, ame- lyet szúrós tárgyakkal kell óvni boszorkányság ellen. Ebben hagyják száradni néhány napig a levágott kölesfejeket, majd kicsépelik, körülmetélési énekeket énekelve. Nők és gyerekek nem lehetnek jelen. A férfiak meztelenek, pénisztokban, táncolva-énekelve csépelnek. A rostálás befejező műveletekor levágják egy csirke fejét a magok fölött, és fött jamgyökeret dobálnak rá. A Föld Örzője beborítja a magokat a kosárba, egy vörös fulani süveget borít rá, és futva viszi a faluba, a szérüskertből a magtárba. A termés végre biztonságban van, nem érheti rontás. A szérüskert szimbólumok és tilalmak fészke. Van egy ún. „igazi földművesek" kasztja, akikre speciális óvintézkedések vonatkoznak. Várandós nő nem mehet a szérüskertbe, mert hamarabb szülne vagy elveszítené a magzatot a köles hatalmas termékenységi ereje miatt. Az első menstruálót az őrlőkunyhóba zárják három napra, ahol a kölesböl lisztet őrölnek. Kicsírázott kölest csak rokonok fogadhatnak el. A kovácsok, akikkel tiltva van a közrendűekkel létesített szexuális kapcsolat, nem léphetnek egy asszony földjére, ahol köles nő. A legtöbb női vagy nőkre vonatkozó termékenységi rítust csak a férfi rítusokból levezetve lehet megérteni. A csillag alakúra nyírt frizurát pl. a nőrokonok a halott nő korsórítusán viselik, de számos alkalommal férfiak is hordják.

ADoajók nem fejik a marhákat (ellenben a Fulanikkal, akiknek fö táplálékuk a tej) és nem is élelem (pl. húsfogyasztás) miatt tenyésztik őket. Egy törpemarha-fajt tartanak, amelynek nincsen púpja és tejet is alig ad. Ideális esetben ünnepre vágják őket, pl. a halottak tiszteletére tartott ünnepen (vö. badeni szarvasmarhaáldozatok, HoRVÁTH 2010), de lehet marhával fizetni a feleségért is. Ezért a szarvasmarha a társadalmi problémák egyik fő szabályozója, és ínség-bőség faktor is. Tartanak szárnyasokat, de tojást sem esznek, sőt, visszataszítónak találják a gondolatát is („Nem tudod, honnan jönnek?"). Az edényeket a kutyákkal nyalatják $\mathrm{ki}$, így mosogatnak. Ez azonban nem valami kivételezés a kutyákkal, mert elég mostohán bánnak velük: nem fekhet pl. a kunyhóban és nem adnak nekik enni sem. A szegregált specialisták sok olyat ehetnek, amit mások nem: pl. ehetnek kutyát és majmot.

A betegségeket több osztályba sorolják: vannak ragályok; boszorkányok vagy növények által okozott rontás; tünetek amelyeket a holtak szellemei okozhatnak; és szennyeződések, amelyeket a tiltott dolgokkal vagy emberekkel való tisztátalan érintkezés okoz. Ez utóbbi elkerülésére szabályozások sora vonatkozik. Ilyen például a vízfogyasztás. A kovácsok nem húzhatnak vizet másokkal, másoknak kell megkínálniuk őket. A síkvidékiek nem ihatnak hegyi doajo vizet, csak ha a helyiek felkínálják. Az esőfőnökök pedig nem ihatnak esővizet. Ez egy szabályozott csere, amely irányítja a nők, az élelem és a víz áramlását a három csoport között.

Csak a ragályokat és a boszorkánysággal okozott véletlen sérüléseket lehet gyógynövényekkel gyógyítani. Elhívnak egy specialistát, aki jóslás segítségével meg tudja állapítani a betegséget, és hogy mi váltotta ki. Aztán jön a Gyógyító által javasolt gyógymód. Általában három jóslásból felderíthető a betegség. Ha a 
beteg nem tud elmenni a gyógyítóhoz, egy kis szalmát küld a magtára tetejéböl a jósláshoz, ami őt képviseli: ez a férfi lakhelyének legprivátabb, legszemélyesebb területe. Ha egy Ős a felelős, akkor az embert elküldik a koponyaházba, hogy vért, ürüléket vagy sört fröcsköljön az alkalmatlankodó Ös koponyájára. A szennyeződések bonyolultabbak. A halottakkal való szennyeződés gyógymódja a halott személyes tárgyainak az áldozathoz való dörgölése. A legsúlyosabb fertőzések a kovácstól és a fazekastól származhatnak: velük vagy a tárgyaikkal való túlzott érintkezés olyat okoz, amit „benőtt vaginának” vagy „besüllyedt ánusznak” neveznek nők és férfiak esetében, korrelálva a körülmetélés misztériumával, amely az ánuszra tereli a beavatatlan figyelmét a péniszről. Vannak mágikus kövek, amelyek betegséget okozhatnak: ezekkel jól lehet keresni, mert csakis a tulajdonosokhoz lehet fordulni az ellenszerért. A boszorkányságot közeli rokonok terjesztik hússal vagy földimogyoróval. Lidérce, amely egy kiscsibéhez hasonlít, fél az éles tárgyaktól, és egy bagoly viszi a szárnya alatt: ezért a Doajók rettegnek a baglyoktól. Kiszívja a vért és megöli az embereket és a marhákat. Úgy lehet védekezni ellene, ha szúrós bogáncsokat és tarajossül tüskéket helyeznek a kunyhó tetejére. A boszorkányság egy inverz fogalom: az emberek, akik boszorkányság miatt halnak meg, valójában nem a boszorkányok áldozatai, hanem ők maguk boszorkányok, akiknek a varázserejét, amit a körülmetélés során szereznek, megsebezték bübájokkal. Ezért ha a boszorkányerő megsérül, véget ér a védőerő és a tulajdonos boszorkánnyá válik, majd meghal. Ma a Doajók ezzel magyarázzák a még körülmetéletlen fiúk gyakori halálát, akik a városba mennek tanulni vagy dolgozni. A boszorkánysággal gyanúsítottakat próbának vethetik alá: a férfinak sört kell innia amibe előzőleg bemártották a körülmetélő kést: ha bűnös, gyomra felpuffad és meghal. Máskor mérgező kaktusszal kevert sört itatnak velük: ha nem hánynak, meghalnak, ha fehéret hánynak az ártatlanságot, ha vöröset, az bűnösséget jelent. Utóbbi esetben a bünöst a kovács felakasztja. A gyanúsított nőnek végig kell sétálnia a halottak koponyáin: ha a rontást ő okozta, belehal. A boszorkányság jeleinek bizonyosságát nem dühvel, hanem csendes elégedettséggel fogadják, és megkezdik a gyógyító által rendelt rítusok elvégzését.

A Doajók félnek a sötétben, ezért sötétedés után nem merészkednek a falu kerítésén túl, mert odakint varázslat van: pl. lidércet szállító baglyok, és az óriás 'Paprikafej', egy helyi mitologikus szörny. A kószálás pedig amúgy is gyanús: házasságtörő viszonyra utal.

Szexuálisan viszonylag fiatal koruktól aktívak (kb. 8 évesen), bár ezt nehéz pontosan megsaccolni, mivel nem tudják, hány évesek, és nincs különösebb időmérő rendszerük sem (bár férfi és női éveket különböztetnek meg, és bizonyos rítusokat, pl. körülmetélést csak férfiévben végeznek). Ezért időpontokat, találkozókat, ünnepek kitűzését illetően is nagyon pontatlanok. A fiúk együtt hálhatnak a lányokkal, és a házasság előtti terhességet sem stigmatizálják, inkább örömteli jelnek, termékenységnek veszik. A menstruáció azon- ban a gyengeelméjüség veszélyével fenyeget, ha a férfi érintkezésbe kerül vele. A körülmetélés bonyolítja tovább a dolgot, amely tíztől húsz éves korig bármikor megtörténhet, mivel minden helyi fiút egyszerre vágnak meg. A férfiak megházasodhatnak, gyermekük is születhet, mielőtt körülmetélnék őket, a körülmetéletlen férfiaknak azonban nőies „stichjük” van: a beavatottak szerint asszonyszaga van a piszkos fitymájuknak; nem vehetnek részt férfi-eseményeken; és nőkkel temetik el őket. A legrosszabb, hogy nem esküdhetnek a késükre, ami a legerősebb fogadkozásnak számít: „A késemre mondom” kifejezés a körülmetélő késre utal, arra a nagyerejü tárgyra, amely képes elpusztítani a boszorkányokat, és mindenképp végezne egy nővel (vö. a badeni férfi idolokon feltűnő beavatási mellszalaggal és az azon függő késsel). A szexuális aktusokra a férfi kunyhójában kerül sor, a nők által kialakított rotációnak megfelelően. A szexualitás és a gyengédség, amit azonos vagy ellenkező nemüek egymás iránt éreznek, két, teljesen külön kategória, és az egyik (szexuális aktus) kizárja a másikat (barátság). Előbbi inkább közönséges és agresszív. Az asszonyok azonban nem teljesen kiszolgáltatottak: végső büntetésként egyszerüen elhagyják a férjüket. Ilyen esetekben a férj bajban van, mert tudja, nehezen fogja tudni visszaszerezni a marhákat, amit a feleségéért fizetett. Ezért a menyasszony-válságként fizetendő marhák tényleges átadását addig halogatja, ameddig csak lehetséges. A sürün tönkremenő házasságok miatt ez a legtöbb bíráskodás tárgya is, mivel ugyanaz az asszony vagy marha az xedik férje után többször is elöfordulhat a követelések listáján. A férj ezért nem a szépség szempontjából választ feleséget, inkább engedelmes és jó kedélyű leányra vágyik. Egy nő nem láthatja a péniszt körülmetélés után, és a férfi sem láthat vaginát. A nemi aktus titkos: teljes sötétségben történik, és egyik fél sem meztelen. A nő sosem távolítja el levélcsomóját, amit elöl-hátul visel, és a férfiak sem az ágyékkötőt, csak az alatta hordott tökből készült pénisztokot. A nők díjazást várnak a szexuális szolgáltatásért, még a házasságban is: férj és feleség szigorú elszámolásban van egymással.

A körülmetélés, vagyis a férfivá avatási rítus nagyon durva: az egész péniszt meghámozzák teljes hosszában. A beavatkozás a halál és az újjászületés folyamatán keresztül átalakítja a természetes születéskor tökéletlen lényt tökéletes férfiemberré. A körülmetélteket 9 hónapig elszigetelik az asszonyoktól. A nők elvileg nem tudnak erről semmit. Azt mondják nekik, hogy egy olyan operációról van szó, amelynek során lezárják az ánuszt egy darab marhabőrrel. A leplezés érdekében mindenféle kitalációra van szükség, és a székelés a férfiaknak sok problémát okoz abból a szempontból, hogy teljes titokban és fedezékben kell végrehajtani, ami néha igen körülményesen kivitelezhető. Valójában a nők pontosan tudják, mi történik, de nyilvánosan ezt nem ismerhetik be, és a részletek titokban tartása miatt nem látják át a dolgok egészét. Bár a szexuális érintkezés miatt tudhatják, hogy mi van a férfi pénisszel és az ánusszal, azt nem tudják, 
hogy az egész rítus gyakorlatilag megegyezik azzal, amit a halottak özvegyei végeznek a gazdag férfiak halála után néhány évvel tartott ünnepeken. Azt sem tudják, hogy az egész koponyaünnep a fiúk körülmetélési rítusának mintájára van kialakítva. A kultúra teljes modellje tehát csak a férfiak számára elérhető a teljes beavatási titkokkal (rítusok, énekek, táncok, tárgyak). A férfiak úgy gondolják, az univerzum végső titkainak őrzői, és ez titkos, amiről nem beszélhetnek; a nők pedig azt hiszik, azok az információk, amit ők tudnak annyira érdektelen, hogy azt nyugodtan elmondhatják bárkinek. A nyelvi kifejezés további érdekessége, hogy a doajo nyelvben az ember nem elkövet, tesz, gyakorol valamit, hanem mondja. Tehát egy nő pl. nem házasságtörést követ el, hanem „mondja” azt.

A férfi és a női élet elkülönül egymástól. A férfinak több felesége lehet, de jobbára a férfiak férfi, a nők női társaságban töltik életüket. $A$ földművelést külön végzik, mindketten megtermelik a saját élelmüket, bár segíthetnek egymásnak. Az asszony elkészíti az ételt, de a férfi külön eszik, esetleg a fiával.

Amikor egy Doajo meghal, megszólalnak a beszélő mély haláldobok, és hírül viszik a falvaknak. A testet helyi gyapotból és erre az alkalomra a halott fivérei által levágott marhák bőréből készült halotti lepelbe tekerik. A nők szaladgálnak a gyász leveleibe öltözve, jajveszékelnek, és üres tökedényeket ütögetnek öszsze. A falu özvegyei a férfi halottak számára elkerített helyen ülnek, nem szabad megmozdulniuk és beszélniük sem. A halott veje a marhakarámba állítja a feleségét, és a hasára hajigálja az áldozati felajánlásokat: ez jelzi a családok közti kapcsolatot. Akik feleséget adtak a halott családjába, azok a rokonaik arcába dobálják a felajánlásokat, nagy tréfálkozások között, mivel ez rendes körülmények között nagy sértés, itt azonban épp ellenkezőleg. Akikkel a halott együtt volt körülmetélve, azok „elmennek együtt kakálni a bozótba”: burkolt utalás az együttes élményre és arra, hogy az ánusz valójában nincs is lezárva. Másnap, kora reggel a férfiak kimennek a keresztútra. Ketten leülnek egymással szemben, füvet tesznek a fejükre, és az egyik azt mondja: „Add nekem a pinádat.” Erre a másik: „Tiéd lehet”. Közösülnek: egy bottal csinálják. Egy férfi felgyújtja a füvet. Kiabálnak. Csatlakoznak a többiekhez, és ezzel vége. A férfiak vörös süveget erősítenek a halott testre, olyat, amit a körülmetélési jelölt visel. Ide-oda lökdösik és körülmetéléssel fenyegetik. Egy meztelen fiút fektetnek a holttestre, és egy vörös fonalat vágnak le a péniszéről, imitálva a körülmetélést. A rítusok után guggoló helyzetben elföldelik.

Úgy két héttel később a fejet eltávolítják a leplen erre a célra hagyott vékonyabb részen át. Megvizsgálják, nem találhatók-e rajta boszorkányság jelei (jelenlétéröl a felső állkapocs alatti két tüske árulkodik: ha fekete vagy vörös, az azt jelenti, hogy boszorkányság okozta a halálát), majd egy edényben egy fára helyezik. A leopárd rendkívül fontos helyet foglal el (bár mára kihalt) a Doajó világ osztályozásában (vö. perzsa oroszlán a balatonőszödi leletanyagban): emberek és marhák gyilkosa, ezért az emberi természet ezen vad és agresszív aspektusával azonosítják. A körülmetélőknek, akik emberi vért ontanak, úgy kell morogniuk mint a vadászó leopárdnak; a megvágott fiúk fiatal leopárdnak öltöznek; ha valaki megöl egy leopárdot ugyanazon a rítusokon esik át, mint aki megölt egy férfit; a nagyhatalmú és veszélyes esőcsinálók leopárddá tudnak változni; és az embergyilkosokat leopárdként emlegetik. Amikor a koponyát fára helyezik egy edényben, azt a tényt hangsúlyozzák, hogy a leopárd is felvonszolja a zsákmányát egy fára, és ott eszi meg. Másképpen bánnak a férfi, a női, és a körülmetéletlenek koponyáival. A férfiakét elhelyezik a bozótban a kunyhó mögött, ahol végső nyugalomra lelnek. A halott férfi íját a koponyaház mögé erősítik.

A női koponyákat egy kunyhó mögött abban a faluban, ahol a nő született: halálakor tehát visszaköltözik szülőfalujába a letelepedési és a házasodási-rokonsági viszonyok szabályai szerint. A nő vizeskorsóját a férj vagy a fia visszaviszi a szülőfalujába, a nő fivéreihez. A korsórítuson a halott nő korsóját, mint egy körülmetélési jelöltet, úgy díszítik fel, a férfi a fején viszi. A faluba érve a marhakarám egy sarkába, egy gödörben, amelybe előzőleg köveket tettek, összetörik (sok ehhez hasonló gödör van badeni településeken!). Ez biztosítja a marhák termékenységét, de elveheti az életerős férfiakét, ezért csak impotens öregek közelíthetik meg. A férfiak narcisztikus táncot járnak tükrökkel, a körülmetélési fivérek felmásznak a halott kunyhójára és a tetőgerinchez dörzsölik az ánuszukat. A nők furcsa dolgokat produkálnak pénisz alakú jamgyökerekkel, imitálva, amit a fiúk csinálnak, mikor körülmetélik őket. Más szóval a halottak özvegyeit úgy kezelik, miután végső búcsút vettek a férjüktől, mintha most metélték volna körül őket. A férjüket, miután átestek a koponyarítuson, szintén. A közös pont az, amikor el lehet helyezni a koponyákat a koponyaházban: ez a körülmetélési rítus végső csúcspontja. A kirekesztés után visszakerülhetnek a hétköznapokba.

Néhány év elteltével a holtak szellemei elkezdhetik zaklatni az élőket: meglátogatják álmukban, betegséget okoznak, nem költöznek be a nők méhébe, tehát megállítják a termékenységet, stb. Ez jelzi, hogy eljött az ideje egy koponyaünnep megrendezésének.

Az ünnepre a nők a levélcsomók helyett ruhacsíkokat viselnek, ez jelzi, hogy nyilvános eseményröl van szó, amelyen ők is részt vehetnek. Ugyanaz az ember több különböző szerepben is felléphet az ünnepségen. Egy férfi egyszerre volt bohóc (rajtuk kívül más nem nyúlhat a koponyákhoz), a halott férfi öccse, akinek az ünnepet szervezték, tehát főszervező, és a koponyaházi varázsló szerepét is ellátta.

A falu mellett voltak a halottak koponyái, elkülönítve a nőké és a férfiaké (vö. badeni izolált koponyaleletek, többségük megállapíthatóan férfiaké: HoRVÁTH 2010c). Kecskéket, marhákat, birkákat és csirkéket vágtak le nagy számban. Ürüléküket a koponyákra dobálták és a vért ráspriccelték. A bohócok verekedni kezdtek a tetemekért, tocsogtak a sárban, vérben, ürülékben, és ezt megpróbálták mindenkire rákenni. Rettenetes a bűz, és többen hányni kezdenek, ami 
mindazt tovább fokozza. Aztán „üresjárat” következik, órákra, vagy akár másnapig. Majd egyszerre több dolog történik. Az utolsó ürülék-hajigálási kör után a bohócok elkezdik megtisztítani a koponyákat. A férfiak visszahozzák a faluból származó nőket és beöltöztetik őket Fulani harcosoknak. Egy dombon táncolnak, lándzsákat lóbálnak a beszélő sípok kíséretére: ezek úgy szólnak, hogy imitálják a politon doajo nyelv hanglejtéseit, tehát, miképpen a dobokkal, beszédszerüen kommunikálni lehet velük. A sípok arra buzdítanak, hogy mutassák meg a férjük gazdagságát, ezért különböző státuszszimbólumokkal aggatják tele ruhájukat. A falu másik részében azoknak a férfiaknak az özvegyei vannak, akiknek az ünnepet rendezték. Hosszú füszoknyában táncolnak, a fejükön növényekből készült kúpos süveggel. Egy harmadik csoport a körülmetéletleneké: késeket lengetve annak a férfinak az iját hozzák, akinek ez az ünnepe, és spontán verekedésbe kezdenek a már körülmetéltekkel. A férfiak közben veszekedések közepette bebugyolálják a megtisztított koponyákat egy olyan ruhába, amely egy körülmetélt ruhája volt. A női koponyákat félredobják, megfeledkeznek róluk. Minden gyereket és nőt elzavarnak. A férfiak koponyáját ide-oda lökdösik, sípokat fújnak. A magyarázat szerint: „Körülmetéléssel fenyegetik a holtakat". Egy férfi egyenként a fejére emeli a koponyákat, és kísérteties melódiába fognak gongokkal, dobokkal, mély furulyákkal kísérve. Az a férfi, aki a koponyákat viszi a táncban, duuze viszonyba kell legyen a halottal (ez egy rokonsági terminus, egy közös rokon legalább a dédapa generációjából egy női ággal közöttük: egy embernek több is van, és ez alkalmas arra, hogy belölük kisebb kört szervezve együtt végezzenek rituális tevékenységet). A halotti lepelből uszályokat húznak ki a ringatózó férfiak. Mások felveszik az erre az alkalomra leölt marhák véres bőrét, koponyájuk a sajátjukon, egy darab nyers hús a foguk közé szorítva, körözni kezdenek a koponyák körül. A falu bejáratánál az özvegyek tovább táncolnak és hívogatják a holtakat, akik lassan körbejárnak a központi fa körül, mielőtt odahelyezték őket, ahol a levágott marhák koponyái ki voltak téve egy kapu fölé. Egy férfi ekkor, az ünnep szervezője, ezt kiáltja: „Nekem köszönhető, hogy ezeket a férfiakat körülmetélték! Ha nem lenne a fehér ember, megöltem volna egy férfit!" Innentől az esemény sörivászattá ás általános tánccá fajulva ér véget. Régen valóban megöltek egy férfit az ilyen ünnepeken, és a koponyáját kővel darabokra zúzták, a fehér kormányzat azonban ezt megtiltotta: ekkor került be ez az új „fehér ember”-formula a rítusba.

Minden rítus és kritikus élethelyzet Doajóföldön ugyanazt játssza el lerövidített vagy kicsit megmásított változatban, ami a fiúk körülmetélésekor történik, és minden fontos szezonális ünnepet a körülmetélés kifejezéseivel írnak le. Minden struktúra ehhez igazodik: ezért bukkan fel a körülmetélési ruha a halott nő vizeskorsóján, a holttest begöngyölésekor, vagy a füszoknyás táncosok süvegében, a köleskupacon, stb. A kezdet és az alaptörténet azonban a Fulanik megjelenésekor lejátszódott interkulturális folyamatokból eredeztethető: a történetnek „A fulani vénasszony agyonverése" a címe.

A történetben „....a Fulani öregasszony fia megbetegszik, mert a füben szaladgálva megvágja magát. A pénisze megdagad, tele gennyel: az öregasszony megvágja egy késsel, a gyerek meggyógyul, a pénisze pedig „gyönyörü” lesz. Erre a Fulani öregasszony megvágja a másik fiát is. Ez egy nap elmegy sétálni egy Doajo faluba, és a Doajók meglátják. Látják azt is, hogy ez jó. Erre elvették a körülmetélést, és agyonverték a Fulani vénasszonyt. Így kezdődött, mert a Doajók nem ismerték a körülmetélést korábban. Megtiltották az aszszonyoknak, hogy lássák. De a Fulani nők láthatják."

Ezt az agyonverést több eseményen újra eljátszszák, pl. a körülmetélésen is. A felnőttkor küszöbén álló fiatalokat úgy kezelik, mint az aratás előtt álló növényeket. A körülmetélt fiúk pedig akkor térnek vissza faluba, amikor az új termést hazahozzák. Az esőcsinálás során a hegyeket úgy tekintik, mint a „Föld koponyáit”. Közös modellek, közös sémák, egyetlen szimbolikarendszer minden rítusban. Az esőfőnökök összekapcsolják az esőt és az emberi termékenységet. Az „igazi földművelő" aratása a növények termékenységét a körülmetéléssel. Doajoföld fő gyümölcsét úgy kell kezelni, mint a koponyákat, és a marhaszentélyre kell helyezni, ami megvédi a falut a skorpiók áradata ellen. Amikor az esőcsináló tisztára törli a mágikus esőcsináló köveket, hogy megkezdődjön a száraz évszak, azon a napon felégetik a hegyet is, amit a „Fiú feje búbjának” neveznek, hogy „szárítsák”. És ez ugyanaz a nap, amikor az új termést beviszik a faluba, és a körülmetéltek hazatérnek. A fő motívum a nedvesből szárazra változtatás. A fiúk, mikor kimennek a faluból a körülmetélésre, „nedvesek és büdösek”: három napig térdepelnek egy folyóban. Amikor megvágják őket, az esőnek folyamatosan esnie kell. Fokozatosan hagyhatják el a folyóparti tábort, és haladhatnak a hegyek felé, „száradni és tisztulni”. Csak a száraz évszakban térhetnek vissza a faluba, és a szentély lábához vezetik öket, ahol a halott marhák koponyái vannak kitéve: itt dobálják rájuk az első termést, amit aznap hoztak haza. A termékenység valamennyi egymástól különböző szféráját egyetlen rendszerbe illesztik, a száraznedves évszakok járása szerinti szimbolikára építve.

A Baden-komplexum spirituális élete, vagy mai szóval, bár mindenképpen helytelenül: vallása Öskultusz volt, amely sok tekintetben és a legtöbb esetben a Halottkultuszt jelenti. A társadalom feltehetően elmozdult arról a korábbi neolitikus szintröl, amely alapvetően egalitárius volt, bár különböző vezetőket, specialistákat már ekkor kiemelt. A középső rézkor végi változások a mobilitás, a klímaingadozás és egyéb külső tényezők miatt megbontották a sokáig egy helyben lakó, földművelő, nagycsaládokban szerveződő közösségeket, elkezdődött egy intenzívebb és szinte folyamatos népmozgás, amely magával hozta a rövidebb letelepedési stádiumok során kialakuló eltérő, jóval tarkább letelepedési mintázatok kialakulását (nyílt társadalmak kialakulása a korábbi zárt, vérségi helyett), és a társadalmi rétegek, specializációk egyre radikálisabb 
elkülönülését. A nyugat-közép-európai tóparti településeken olyan kulturális sokszínüség jött létre, hogy az ottani régészek ezeket a lelőhelyeket már nem sorolják be kulturálisan. Arbon Bleiche 3 svájci településén ugyanúgy előfordult a Pfyn, Horgen és a Boleráz, és a leletek számából, tafonómiájából nem lehetett finom arányositással Pfyn-Horgen, Horgen-Boleráz vagy Boleráz-Horgen (stb.) településröl sem beszélni, mivel a kultúra-specifikus leletek nem korlátozódtak egyetlen és jól körülhatárolható jelenségre (pl. házra vagy háztartás-körzetre), amely alapján a települést önálló Pfyn, Horgen vagy Boleráz háztartásokra vagy részekre (körzetekre) fel lehetne osztani (vö. Hofmann 2013). Ennek és további találmányoknak, pl. a fejlődő úthálózatnak, kereskedelemnek és vízi-szárazföldi közlekedésnek, valamint a magasabb társadalmi igényeknek köszönhetöen megkezdödött a környezetnek az ember képére való formálása. $A z$ a fajta kettősség, lüktetés, bipolaritás, részben folytonosság részben pedig újítás, amely mind a transzhumáló életmódban (állandó és időszakos szállások közti ingázás), mind a társadalmakban érezhető (kiemelkedő rétegek és egyenlőség, vérségi szerveződés és azok felbomlása, idegenekkel való együttélés módjának kialakítása rövid letelepedési időszakokra), áttevődik a hétköznapi és a vallási, vagyis a profán és a rituális világképre is. $A$ korszak hasonló vagy az idő nyomására változó rítusai a korábbi neolit rítusok helyett már közösségi léptékben, közösségi tereken játszódnak, nem házakban, családi szinten, és az egész közösséget bevonzzák, nemcsak a lakóház lakóit.

A profán és a szent: egyik a másiktól ma is elválaszthatatlan, amikor kutatjuk, és a közösségek akkori felfogásának köszönhetően akkor sem választották szét öket egymástól. A különböző kultikus tárgytípusok egy jelenségen belüli; és ugyanazon kultikus tárgytípusok többféle jelenségen belüli, utóbbi időben hiteles feltárási adatok alapján egyre szaporodó száma is azt jelzi, hogy átjárás és behelyettesítés létezett az idolok, a maszkok/maszkírozás-maskarázás, a sztélék, az emberi tulajdonságokkal felruházott edények, és a temetési rítusok, beavatási rítusok, termékenységi rítusok között, amelyek a társadalmak gazdasági, leszármazási, társadalmi rétegzettségi rendjének és hitvilágának megfelelően szerveződtek és épültek fel egyetlen rendszerré, amit ma úgy hívunk: régészeti kultúra. Mindezek, bár néha eltérően, de mindig valahogyan egymást kiegészítve vagy egymáshoz illeszkedve - mozaikokból összeállva egyetlen képpé - az adott kultúra egészét alkották.

\section{Irodalom}

Arnold, E. R. \& Greenfield, H. J. 2006: The Origins of Transhumant Pastorialism in Temperate South Eastern Europe: A Zooarchaeological Perspective from the Central Balkans. British Archaeological Report International Series 1538, Oxford: Archaeopress.

Baldia, M. O., Frink, D. S. \& Boulanger M. T. 2008: The Earthen LongBarrow of Džbán, Moravia, Czech Republic and its Implications for the Interaction between the Nordic Funnel Beaker and the Southern Baden Culture. In M. Furholt, M. Szmyt and A. Zastawny (eds), The Baden Complex and the Outside World. Proceedings of the $12^{\text {th }}$ Annual Meeting of the EAA in Cracow 19-24 ${ }^{\text {th }}$ September, 2006. Studien zur Archäologie in Ostmitteleuropa//Studia nad Pradziejami Europy Środkowej 4, 263-289.

BALEN, J. 2011: Đakovo Franjevac. Kasno bakrenodobno naselje / Late eneolithic settlement) (Musei Archaeologici Zagrabiensis Catalogi et Monographie vol. 7), Zagreb, 2011.

BanneR, J. 1956: Die Péceler Kultur. Archaeologia Hungarica 35, Budapest: Akadémiai kiadó.

BARLEY, N. 1983: Symbolic structures. An exploration of the culture of the Dowayos. Cambridge Univesity Press.

Barley, N. 1984: Placing the West African Potter. In J. Picton (ed.), Earthenware in Asia and Africa, 93-105. London: Percival David Foundation.

BARLEY, N. 1994: Smashing pots: feats of clay from Africa. London: British Museum Press.

Bertemes, F. 2010: Die Maskengräber der kupferzeitlichen Nekropole von Varna, Bulgarien, und ihre Bedeutung zum Verständnis der Idolplastik der Karanovo IV-Kultur. In H. Meller and R. Maraszek (eds), Masken der Vorzeit in Europa (I). Internationale Tagung vom 20. bis 22. November 2009 in Halle (Saale). Tagungen des Landesmuseums für Vorgeschichte Halle (Saale) 4, 85-97.
BelÉNYEsY, K., Hontı, Sz. és KIss, V. (eds) 2007: Gördülő idő. Régészeti feltárások az M7-es autópálya Somogy megyei szakaszán Zamárdi és Ordacsehi között - Rolling time. Excavations on the M7 Motorway in County Somogy between Zamárdi and Ordacsehi. Kaposvár/Budapest: SMMI-MTA RI

Bistáková, A. \& Pažinová, N. 2010: (Un)Usual Neolithic and Early Eneolithic mortuary practices in the area of the North Carpathian Basin. Documenta Praehistorica XXXVII, 147-159.

BondÁR, M. 1998: Ein kupferzeitlicher Krug aus Bátaszék. CommArchHung 1998, 21-31.

BondÁR, M. 1999-2000: Neue und vergessene Idole der Badener Kultur. Acta Archaeologica Academiae Scientiarum Hungaricae 51, 23-34.

BondÁR, M. 2008: The Paraphernalia of Cult Life in the Late Copper Age. Acta Archaeologica Academiae Scientiarum Hungaricae $59,171-181$.

BondÁR, M. 2009: The cemetery. In M. Bondár and P. Raczky P. (eds.), The Copper Age cemetery of Budakalász, 11-303. Budapest: Pytheas.

Bóka, G., Gyucha, A., Olä, I., M. L. Galaty, Kasztovszky, Zs., Koromán, N. és MedgyesI, P. 2013: A gyanú árnyékában. Egy dél-békési vésett kősztélé vizsgálatainak előzetes eredményei. Öskoros Kutatók VIII. Összejövetele 2013. 10. 16-18, Déri Múzeum, Debrecen. Öskori müvészet - Művészet az Öskorban, Konferencia program, 8-10.

BRooks, M. 2011: A tudomány titkos anarchiája. A radikális gondolkodás szabadsága (Free Radicals: The Secret Anarchy of Science). Budapest: HVG könyvek.

Cohen, A. P. 1992: Rites of initiation and the mystery of the self. In J. A. Fernández de Rota y Monter (ed.) Simposio rito y misterio. Universidade da Coruna, Servicio de publicaciones, 147-160. 
Cucuteni Culture art and Religion / Kultúra Cucuteni sztuka I Religia. Suceava, 2009.

DANI, J. és HoRvÁtH, T. 2012: Öskori kurgánok a magyar Alföldön. A Gödörsíros (Yamnaja) entitás magyarországi kutatása az elmúlt 30 év során. Áttekintés és revízió. Budapest: Archeolingua.

DARÁzsY, B. (ed.) 2010: Fifty years of the Archaeological Institute of the Hungarian Academy of Sciences. Budapest: MTA Régészeti Inézet.

DIMITRIADIS, G. 2008: Looking for metals: Megalithic monuments between reality and mithology. In R. I. Kostov, B. Gaydarska, M. Gurova (eds) Geoarchaeology and Archaeomineralogy. Proceedings of the International Conference, 29-30 Octobe 2008 Sofia, Publishing House „St. Ivan Rilski”, 205-210, Sofia.

DıMıTRIJeVIĆ, S. 1976: Idolplasika u Lasinjskoj kulturi. Godišnjak 13, 59-83.

ENDRÖDI, A. (ed.) 2004: Hétköznapok és vallásos élet a rézkor végén. A Baden-kultúra 5000 éves emlékei Budapesten (Everyday life and spirituality at the end of the Copper Age. 5000 years remains of the Baden Culture in Budapest). Temporary exhibition at the Budapest Historical Museum XII. 2004-III. 2005. Budapest: Budapesti Történeti Múzeum.

Dumitrescu, V. 1974: Arta Preistorica in Romania. Bucuresti.

FEKETE, M. 2004: Gondolatok egy neolitikus idoltípus ürügyén. http:// okorportal.hu/wp-content/uploads/2012/12/2004_2_fekete.pdf

Durman, A. (ed.) 1988: Vučedol treće tisućljeće p.n.e. / Vučedol three thousand years b.c. Zagreb.

Durman, A. (ed.) 2000: Vucedolski Orion i najstariji europski kalendar / The Vucedol Orion and the Oldest European Calendar. Zagreb.

FLoss, H. 2010: Verborgene Gesichter - Masken und Verkleidungen der Alt- und Mittelsteinzeit. In H. Meller and R. Maraszek (eds), Masken der Vorzeit in Europa (I). Internationale Tagung vom 20. bis 22. November 2009 in Halle (Saale). Tagungen des Landesmuseums für Vorgeschichte Halle (Saale) 4, 49-61.

FuRHOLT, M. 2008: Pottery, cultures, people? The European Baden material re-examined. Antiquity $82,617-628$.

Gosselein, O. 1999: In Pots we trust. The processing of Clay and Symbols in Sub-Sahara Africa. Journal of Material Culture 4:2, 205-230.

GovedARICA, B. 1997: Cernavoda III-Boleráz-Funde im Westbalkan. In C. Becker, M.-C. Dunkelman, C. Metzner-Nebelsick, H. Peter-Röcher, M. Roeder, B. Teržan (eds) Xpovos. Beitrage zur prahistrorischen Arhaologie zwischen Nord- und Südosteuropa. Festschrift für B. Hänsel, International Archaologie-Studia Honoraria Band 1, 149-157.

Grammenos, D. V. (ed.) 2003: Recent Research in the Prehistory of the Balkans. Publications of the Archaeological Institute of Northern Greece, Nr. 3.

GronenBoRn, D. 2010: Eliten, Prestigegüter, Repräsentationsgräber. Ein Spurensuche nach politischen Organisationsformen. In C. Lichter (red.) Jungsteinzeit im Umbruch. Die „Michelsberger Kultur" und Mitteleuropa vor 6000 Jahren, 243-250. Karlsruhe.

HANSEN, S. 2001: Neolithic Sculpture. Some Remarks on an Old Problem. In P. F. Biehl, F. Bertemes and H. Meller (eds), The Archaeology of Cult and Religion, 37-53. Budapest: Archeolingua.

HANSEN, S. 2007: Bilder vom Menschen der Steinzeit. Untersuchungen zur anthropomorphen Plastik der Jungsteinzeit und Kupferzeit in Südosteuropa. Archäologie in Eurasien Band 20, Mainz.

HARANGI, Sz. 2013: Merre tovább, vulkanológia? a 21. század kihívásai. Magyar Tudomány 2013:8, 959-979.

HavasI, B. 2006: A bagodi idol (Das idol von Bagod). Zalai Múzeum 15, 93-106.

Hofmann, D. 2013: Living by the Lake. Domestic Architecture in the Alpine Foreland. In D. Hofmann and J. Smyth (eds), Tracking the Neolithic House in Europe. Sedentism, Architecture and Practice, 197-229. One World Archaeology. New York: Springer.

Hontı, Sz. és HoRvÁtH, T. 2013: Balatonőszöd-Temetői dűlő (M7/S-10) lelőhely őskori településrészei. Digitális kiadás - dupla DVD. Miskolc/Budapest: MTA BTK RI.
HORVÁTH, T. 2002: Rejtőzködő múlt. Rézkori álarc az M7-esen. Élet és Tudomány 57(23), 711-714.

HoRvÁth, T. 2002a: A unique anthropomorphic representation of Baden culture. Antaeus 25, 423-426.

HoRVÁTH, T. 2002b: Késő rézkori agyagmaszk Balatonőszödröl. Ősrégészeti levelek 4, 31-40.

HoRVÁth, T. 2004: A new human representation from the Baden Culture: Mask from Balatonőszöd. Acta Archaeologica Academiae Scientiarum Hungaricae 55, 179-237.

HorVÁth, T. 2006: Állattemetkezések Balatonőszöd-Temetői dűlö badeni lelöhelyen (Animal burials in the Late Copper Age Baden Site: Balatonőszöd-Temetői dűlő). Somogyi Múzeumok Közleményei 17, 107-152.

HoRvÁTH, T. 2007: Késő rézkori agyagmaszk. In Belényesy, K., Honti, Sz. and Kiss, V. (szerk.) Gördülő idő. Régészeti feltárások az M7-es autópálya Somogy megyei szakaszán Zamárdi és Ordacsehi között - Rolling time. Excavations on the M7 Motorway in County Somogy between Zamárdi and Ordacsehi, 110-111. Kaposvár/Budapest: SMMI-MTA RI.

HORVÁTH, T. 2008: Sozialmorphologische Studie der spätkupferzeitlichen Baden-(Pécel)-Kultur. Mitteilungen den Anthropologischen Gesellschaft in Wien 138, 159-203.

HORVÁTH, T. 2009: The intercultural connections of the Baden „culture”. In G. Ilon (ed.), M $\Omega \mathrm{MO} \Sigma \mathrm{VI}$, Öskoros kutatók VI. Összejövetelének konferenciakötete, Nyersanyagok és kereskedelem, Köszeg, 2009. március 19-21, 101-149. Szombathely: KÖSZ - VMMI.

HoRVÁtH, T. 2010: Manifestationen des Transzendenten in der Badener Siedlung von Balatonőszöd-Temetői Dülő - Kultgegenstände. Praehistorische Zeitschrift 85, 79-119.

HoRVÁth, T. 2010a: Europäische Maskentradition am Beispiel eines spätkupferzeitlichen Fundes. In H. Meller and R. Maraszek (eds), Masken der Vorzeit in Europa (I). Internationale Tagung vom 20. bis 22. November 2009 in Halle (Saale). Tagungen des Landesmuseums für Vorgeschichte Halle (Saale) 4, 109-127.

HoRVÁth, T. 2010b: Manifestation des Transzendenten in der Badener Siedlung von Balatonőszöd-Temetői dülö - Zeremoniengefässe. Acta Archaeologica Academiae Scientiarum Hungaricae 61, $1-48$.

HoRVÁth, T. 2010c: Transcendent phenomena in the Late Copper Age Boleráz/Baden settlement uncovered at BalatonőszödTemetői dűlő: human and animal „depositions”. http://www. jungsteinSITE.de, $1^{\text {st }}$ of September, 2010

Horváth, T. 2011: Hajdúnánás-Tedej-Lyukas halom - The Interdisciplinary Survey of a Typical Kurgan from the Great Plain Region: a Case Study (The Revision of the Kurgans from the Territory of Hungary). In Á. Pető and A. Barczy (eds), Kurgan Studies: An environmental archaeological multiproxy study of burial mounds of the Eurasian steppe zone, 71-131. British Archaeological Reports International Series 2238, Oxford: Archeopress.

HoRVÁTH, T. 2011a: Hagyomány az európai maszk-viseletben egy késó rézkori lelet kapcsán (Tradition in european mask wear: on the occasion of a Late Copper Age finding). In M. Fekete (ed.), „... eleitől fogva" Régész-tanár-ember. A 75 éves Makkay János köszöntése, 185-213, Pécs: PTE BTK-Genianet.

HorvÁth, T. 2011b: A Boleráz, Baden és Kostolac kultúrák kronológiai és térbeli helyzete, és interkulturális kapcsolatai. Specimina Electronica Antiquitatis 12. http://www.okor.tti.btk.pte.hu/ menu/18

HoRvÁth, T. 2012: Networks and Netwars: New perspectives on the Late Copper Age and Early Bronze Age. Typo-chronological relationships of the Boleraz/Baden/Kostolac finds at the site of Balatonőszöd-Temetői dűlö, Hungary. British Archaeoloica Reports International Series 2427, Oxford: Archeopress.

HoRvÁth, T. 2013: Rezension. Mária Bondár - Pál Raczky (Red.): The Copper Age cemetery of Budakalász. Budapest, Pytheas, 2009, ISBN 978-963-9746-72-5. Acta Archaeologica Academiae Scientiarum Hungaricae 64, 331-336. 
Horváth, T. (ed.) 2014: The Prehistoric settlement parts of Balatonöszöd-Temetöi-dülö The Middle Copper Age, Late Copper Age and Early Bronze Age settlements. Varia Archaeologica Hungarica XXXI, 2014, in print.

HoRVÁTH, T. 2014a: Az öskori migráció kérdése az archeogenetikai és izotópos vizsgálatok alapján. Magyar Tudomány 2014: 2.

HoRVÁtH, T. 2014b: Balatonőszöd: A Late Copper Age BolerázBaden opened settlement with human burials and sacrifices. Salzmünde - rule or exception? Halle, in print.

HoRVÁtH, T. 2014c: Die Anfänge des kontinentalen Transportwesens und seine Auswirkungen auf die Boleráz/Badener-Kultur. Germania XXX, 2014, in print.

HoRVÁth, T. \& BALEN, J. 2012: The cultural attribution and dating of the cult vessel from Szelevény-Vadas. Opuscula Archaeologia 36, 7-25.

HoRVÁTH, T. \& KöHLER, K. 2012: Life and Death: Mortuary Rituals of the Baden Culture at Lake Balaton (Transdanubia). Archäologisches Korrespondenzblatt 42, 453-472.

HoRVÁth, T. \& S. SVIngor, É. 2014: The spatial and chronological distribution of the so-called "Baden Culture". In M. Nowak and A. Zastawny (eds), The Baden Culture around the Western Carpathians. Via Archaeologica - Special Edition, Kraków, in print.

Horváth, T., JuhÁsz, I. \& KöHLeR, K. 2003: Zwei Brunnen der BalatonLasinja Kultur von Balatonőszöd. Antaeus 26, 265-300.

Horváth, T., Gherdán, K., Herbich, K., \& Vasáros, Zs. 2007: Häuser der Badener Kultur am Fundort Balatonőszöd-Temetői dülö. Acta Archaeologica Academiae Scientiarum Hungaricae 58, 43-105.

Horváth, T., Sipos, Gy., May, Z., \& Tóth, M. 2010: The date of the Late Copper Age ritual mask from Balatonőszöd-Temetöi dülö. Antaeus 31-32, 499-513.

Kalıcz, N. 1963: Die Péceler (Badener) Kultur und Anatolien. Studia Archaeologica II, 1963, Budapest.

KaLICZ, N. 1973: Über die chronologische Stellung der Balaton-Gruppe. In B. Chropovský (ed.), Symposium über die Entstehung und Chronologie der Badener Kultur, 131-165. Bratislava: Slovakian Academy of Sciences.

KALICZ, N. 1979-1980: Újabb adatok a rézkori hunyadihalmi csoport idörendjéhez (Neue Beiträge zur Chronologie der kupferzeitlichen Hunyadihalom-Gruppe. Szolnok Megyei Múzeumok Évkönyve 1979-1980, 43-59.

KALICZ, N. 2002: Eigenartige Anthropomorphe Plastik der kupferzeitlichen Badener Kultur im Karpatenbecken (A rézkori Baden kultúra sajátságos ember alakú plasztikája a Kárpát-medencében). Budapest Régiségei XXXVI, 11-55.

KaliCz, N. 2007: Az őskori agyagszobrászat kezdetei a Nyugat-Dunántúlon (Die Anfange der urgeschichtlichen Tontstatuetten in West-Transdanubia. In G. Ilon (ed.) Százszorszépek. Emberábrázolás az őskori Nyugat-Magyarországon. Die Wunderschönen. Menschendarstellung im urzeitlichen Westungarn. Wonderful Beauties. Human representations in prehostoric Western Hungary, 8-46. Szombathely: Vas Megyei Múzeumok Igazgatósága.

KERIG, T. 2010: Der Faktor Arbeit im Neolithikum. Steinbearbeitung, Feldbestellung, Schwertransport. In C. Lichter (red.) Jungsteinzeit im Umbruch. Die "Michelsberger Kultur” und Mitteleuropa vor 6000 Jahren, 236-243. Karlsruhe.

KIESELBACH, P. 2010: Silex. Elementarer Rohstoff und begehrtes Importgut. In C. Lichter (red.) Jungsteinzeit im Umbruch. Die „Michelsberger Kultur” und Mitteleuropa vor 6000 Jahren, 203206. Karlsruhe.

Kovács B., I. 2002: A méhi istentriász és népe (The God-triad of Méhi). Gömör-Kishont az öskorban (I). Rimaszombat: Gömöri Múzeum.

KöVECSES, Z. 2005: A metafora. Gyakorlati bevezetés a kognitív metaforaelméletbe / Metaphor. A Practical Introduction. Budapest: Typotex.

KulCsÁR, G. 2009: The beginnings of the Bronze Age in the Carpathian Basin. The Makó-Kosihy-Čaka and the Somogyvár-Vinkovci Cultures in Hungary. Varia Archaeologica Hungarica XXIII, Budapest: MTA RI.
LeUZINGER, U. 2000: Die jungsteinzeitliche Seeufersiedlung Arbon/Bleiche 3. Befunde. Archäologie im Thurgau 9, Frauenfeld.

LICHTER, C. 2010: Wie man sie bettet, so liegen sie. Vom Umgang mit den Toten im 5. und 4. Jt. v.Chr. In C. Lichter (red.) Jungsteinzeit im Umbruch. Die „Michelsberger Kultur” und Mitteleuropa vor 6000 Jahren, 258-266. Karlsruhe.

MAGNY, M. 2004: Holocene climate variability as reflected by midEuropean lake-level fluctuations and its probable impact on prehistoric human settlements. Quaternary International 113 , 65-79.

MAGNY, M. \& HAAS, J. N. 2004: A major widespread climatic change around $5300 \mathrm{cal}$. yr BP at the time of the Alpine Iceman. Journal of Quaternary Science 19(5), 423-430.

Magny, M., Leuzinger, U., Bortenschlager, S. \& HaAs, J. N. 2006: Tripartite climate reversal in Central Europe $5600-5300$ years ago. Quaternary Research 65, 3-19.

Maraszek, R. 2010: Masken und Maskierungen der Bronzezeit in Europa. In H. Meller and R. Maraszek (eds), Masken der Vorzeit in Europa (I). Internationale Tagung vom 20. bis 22. November 2009 in Halle (Saale). Tagungen des Landesmuseums für Vorgeschichte Halle (Saale) 4, 145-159.

MıLosčıć, V. (Hrsg.) 1979: Trojanische Gefäßformen der Frühbronzezeit in Anatolien, der Ägäis und angrenzenden Gebieten. Ein Beitrag zur vergleichenden Stratigraphie von C. Podzuweit. Heidelberger Akademie der Wissenschaften. Internationale Interakademische Komission für die Erforschung der Vorgeschichte des balkans, Monographien Band I, Verlag Philipp von zabern, Mainz am Rhein, 1979.

NAdLER, M. 2010: Spätneolitische Stelen und Petroglyphen? Zu einer Neubewertung der sog. Zeichensteingräber im mittleren Regnitztal. Beiträge zur Ur- und Frühgeschichte Mitteleuropas 63 Varia Neolithica VII, 183-210.

NeustupnÝ, E. \& ZÁpotockÝ, M. 2013: 4.2. The Baden Culture in the Middle Eneolithic Period. In E. Neustupný, M. Dobeš, J. Turek, M. Zápotocký (eds) The Prehistory of Bohemia 3. The Eneolithic, 94-100. Praha: Archeologicky ústav AV CR.

NÉmEtI, J. és DANI, J. 2001: Néhány korabronzkori sír az Érmellékről (Románia) és a Nyírségböl (Magyarország). Some Early Bronze Age graves from the Érmellék (Romania) and Nyírség (Hungary). Some data on the Early Bronze Age of Northeast Hungary and Northwest Romania. Jósa András Múzeum Évkönyve 43, 103-109.

Novotný, B. 1981: Zur Idolatrie der Badener Kultur in der Slowakei. Slovenska Archaeologia 29, 131-138.

Patay, P. 1989: Beitrage zur Kunst der Kupferzeit. MAGW 118/119, 33-43.

PataY, P. 2005: Kupferzeitliche Siedlung von Tiszaluc. IPH XI, Budapest.

Petrović, J. \& Jovanović, B. 2002: Gomolava. Naselje Kasnog eneolitas. Gomolava. Settlements of the Late Eneolithic. Gomolava Knjiga 4, Novi Sad/Beograd

Pétrequin, P., Pétrequin, A.-M., \& Bailly, M. 2006: Vues du Jura francais: les premieres tractions animales au Néolithique en Europe occidentale. In P. Pétrequin, R.-M. Arbogast, A.-M. Pétrequin, S. van Willigen, M. Bailly (eds.), Premiers chariots, premiers araires. La diffusion de la traction animale en Europa pendant les IV ${ }^{\circ}$ et $\mathrm{III}^{\mathrm{e}}$ ère (Centre National de la Recherche Scientifique, Centre d'études Préhistoire, Antiquité, Moyen Âge, CRA 29 Monographies), Paris, 2006, 361-399.

PIggott, S. 1983: The earliest Wheeled Transport. From the Atlantic Coast to the Caspian Sea. London.

Pollex, A. 1999: Comments on the interpretation of so-called cattle burials of Neolithic Central Europe. Antiquity 73(281), 542-550.

RAJNA, A. 2011: Az Abony 49. lelöhely protoboleráz-kori leletei és interpretációs lehetőségei. Studia Comitatensia 31, 96-125.

Pétrequin, P., Cassen, S., \& Klassen, L. 2010: Zwischen Atlantik und Schwarzem Meer. Die großen Beile aus alpinem Jadeit im 5. und 4. Jt. v.Chr. In C. Lichter (red.) Jungsteinzeit im Umbruch. Die "Michelsberger Kultur” und Mitteleuropa vor 6000 Jahren, 191-198. Karlsruhe. 
RAJNA, A. 2011: Az Abony 49. lelöhely protoboleráz-kori leletei és interpretációs lehetöségei. Studia Comitatensia 31, 96-125.

RAmmingeR, B. 2010: Kommunikationsanzeigende Neztwerke. Beile und Äxte. In C. Lichter (red.) Jungsteinzeit im Umbruch. Die „Michelsberger Kultur" und Mitteleuropa vor 6000 Jahren, 198203. Karlsruhe.

Rassamakin, Y. Y. 2004: Die Statuetten des Serezlievka-Typs und zum Problem des Beginns der Bronzezeit in der nordpontischen Steppe. In B. Hänsel and E. Studeníkova (eds.), Zwischen Karpaten und Ägäis. Neolithikum und Ältere Bronzezeit. Gedenkschrift für Viera Nĕmejcová-Pavúková. Internationale Archäologie, Studia Honoraria 21, 149-169.

REICHENBERGER, A. 2010: Totenmasken und verhüllungen der Hallstattzeit. In H. Meller and R. Maraszek (eds), Masken der Vorzeit in Europa (I). Internationale Tagung vom 20. bis 22. November 2009 in Halle (Saale). Tagungen des Landesmuseums für Vorgeschichte Halle (Saale) 4, 159-175.

RışcuTA, C. 1996: Plastica antropomorfă a Culturii Coţofeni (La Plastique anthropomorphe de la Culture Coţofeni). Bulletin Cercurilor Ştiinţifice Studenţeşti 2, 69-76.

Rовв, J. 2009: People of Stone: Stelae, Personhood, and Society in Prehistoric Europe. Journal of Arch. Method Theory 2009:16, 161-183.

RoLA, J. 2009: Construction issues in the north-west (central-european) section of Baltic-Pontic inter-regional routes: the Noteć river crossing in Żuławka Mała - much ado about nothing? BalticPontic Studies 14, 72-87.

RutTKAY, E. 1997: Der erste neolitische Idolkopf aus der Steiermark. Zur Idolplastik der Lasinja-Kultur. In M. Lazić (ed.) Antidóron Dragoslavo Srejović: completis LXV annis ab amicis collegis discipulis oblatu, 181-191. Beograd.

RutTkAY, E. 1999: Jungneolithikum. In J.-W. Neugebauer (eds), Jungsteinzeit im Osten Österreich. Wissenschaftliche Schriftenreihe Niederösterreich, 110-145. St. Pölten/Wien: Verlag Niederösterreichisches Pressehaus.

Ruttkay, E. \& Kramer, E. 2004: Graziella aus dem frühen 4. vorchristlichen Jahr-tausend - Die erste (fast) vollständige Frauenfigur mit Furchenstichverzierung. Schild von Steier, Kleine Schriften 20, 46-54.

SCARRE, C. 2010: Westeuropa im 5. u. 4. Jahrtausend v.Chr. In C. Lichter (red.) Jungsteinzeit im Umbruch. Die „Michelsberger Kultur" und Mitteleuropa vor 6000 Jahren, 141-149. Karlsruhe.

ScHIER, W. (Hrsg.) 2005: Masken, Menschen, Rituale. Alltag und Kult vor 7000 Jahren in der prähistorischen Siedlung von Uivar, Rumänien. Martin-von-Wagner-Museum der Universität Würzburg, 21. April-10. Juli 2005. Würtzburg.

SCHIER, W. 2010. Ein Ritual vor 6800 Jahren: Die Maske von Uivar (Romänien) und ihr Kontext. In H. Meller and R. Maraszek (eds), Masken der Vorzeit in Europa (I). Internationale Tagung vom 20. bis 22. November 2009 in Halle (Saale). Tagungen des Landesmuseums für Vorgeschichte Halle (Saale) 4, 73-85.

SCHLICHTHERLE, H. 2010: Kultbilder in den Pfahlbauten des Bodensees. In C. Lichter (red.) Jungsteinzeit im Umbruch. Die „Michelsberger Kultur" und Mitteleuropa vor 6000 Jahren, 266-277. Karlsruhe.
Schwarzberg, H. 2010: Mirrors and masks? Menschliche Gesichter auf Gefäßen des mittel- und südosteuropäischen Neolithikums. In H. Meller and R. Maraszek (eds), Masken der Vorzeit in Europa (I). Internationale Tagung vom 20. bis 22. November 2009 in Halle (Saale). Tagungen des Landesmuseums für Vorgeschichte Halle (Saale) 4, 61-73.

Sipos, Gy., Horváth, T., MAY, Z., és Tóth, M. 2012: Adatok BalatonőszödTemetői-dülö, késö rézkori rituális álarc keltezéséhez. In A. Kreiter, Á. Petö and B. Tugya (eds.), Környezet-Ember-Kultúra. $A$ természettudományok és a régészet párbeszéde. MNM NÖK 2010. október 6-8-án megrendezett konferenciájának tanulmánykötete, 373-385. Budapest: MNM-NÖK.

Strahm, C. 2010: Kupfer: Prestige, Netzwerke. Ein neuer Werkstoff, der Geschichte schreibt. In C. Lichter (red.) Jungsteinzeit im Umbruch. Die „Michelsberger Kultur” und Mitteleuropa vor 6000 Jahren, 179-187. Karlsruhe.

TeEgen, W.-R. 2010: Schädelmasken aus der Siedlung Hunte 1 am Dümmer (späte Trichterbecherkultur/frühe Schnurkeramik)? In H. Meller and R. Maraszek (eds), Masken der Vorzeit in Europa (I). Internationale Tagung vom 20. bis 22. November 2009 in Halle (Saale). Tagungen des Landesmuseums für Vorgeschichte Halle (Saale) 4, 127-139.

Torma, I. 1972: Die Tierstatuetten der Boleráz-Gruppe von Pilismarót, Basaharc. In F. Bachmayer, E. Ruttkay, H. Melichar and O. Schultz (eds), Idole. Prähistorische Keramiken aus Ungarn. Veröffentlichungen aus dem Naturhistorischen Museum, Neue Folge 7, 24-26. Wien: Verlag Naturhistorisches Museum.

ToRmA, I. 1973: Die Boleráz-Gruppe in Ungarn. In B. Chropovsky (ed.), Symposium über die Entstehung und Chronologie der Badener Kultur, 483-512. Bratislava: Slovakian Academy of Sciences.

VIDEIKO, M. Y. 2000: Studying westerm context of the Tripolje Culture: history and some perspectives. Baltic-Pontic Studies 9, 7-69.

VIRÁG M., Zs. 2004: Településtörténeti és kronológiai kutatások a Dunántúlon és Budapest környékén a középső rézkor első felében (Settlement history and chronology in the first part of the Middle Copper Age at Transdanubia and environment of Budapest). Part I-II, PhD dissertation, manuscript. Budapest: ELTE RI.

VIRÁG M, Zs. 2005: Középső rézkori kerámialeletek Zalavár-Basaszigetről (A Balaton-Lasinja kultúra tipológiájának és belső kronológiájának kérdéseiről) (Middle Copper Age Ceramic Finds from Zalavár-Basaszoget (Some considerations about the typology and chronology of the Balaton-Lasinja Culture). Zalai Múzeum 14, 37-52.

VISY, Zs. (ed.) 2003: Hungarian Archaeology at the turn of the Millenium. Budapest, 2003.

VizDAL, J. 1980: Potiská kultúra na Vychodnom Slovenska. Košice.

Wohin die Toten gehen. Kult und Religion in der Steinzeit. Austellungkatalog, Isensee Verlag, Oldenburg, 2000.

ZsIDI, P. 2005: Kincsek a város alatt. Budapest régészeti örökségének feltárása, 1989-2004. Kiállitás a Budapesti Történeti Múzeumban 2005. május 27-augusztus 20. / Treasures under the city. Survey of the archaeological heritage of Budapest, 1989-2004. Temporary exhibition at the Budapest History Museum 27 May20 August 2005. Budapesti Történeti Múzeum, Budapest. 
